Prepared for the U.S. Department of Energy

under Contract DE-AC05-76RL01830

\title{
Test Plan to Assess Fire Effects on the Function of an Engineered Surface Barrier
}

\author{
AL Ward \\ GT Berlin \\ JW Cammann \\ KD Leary \\ SO Link
}

September 2008

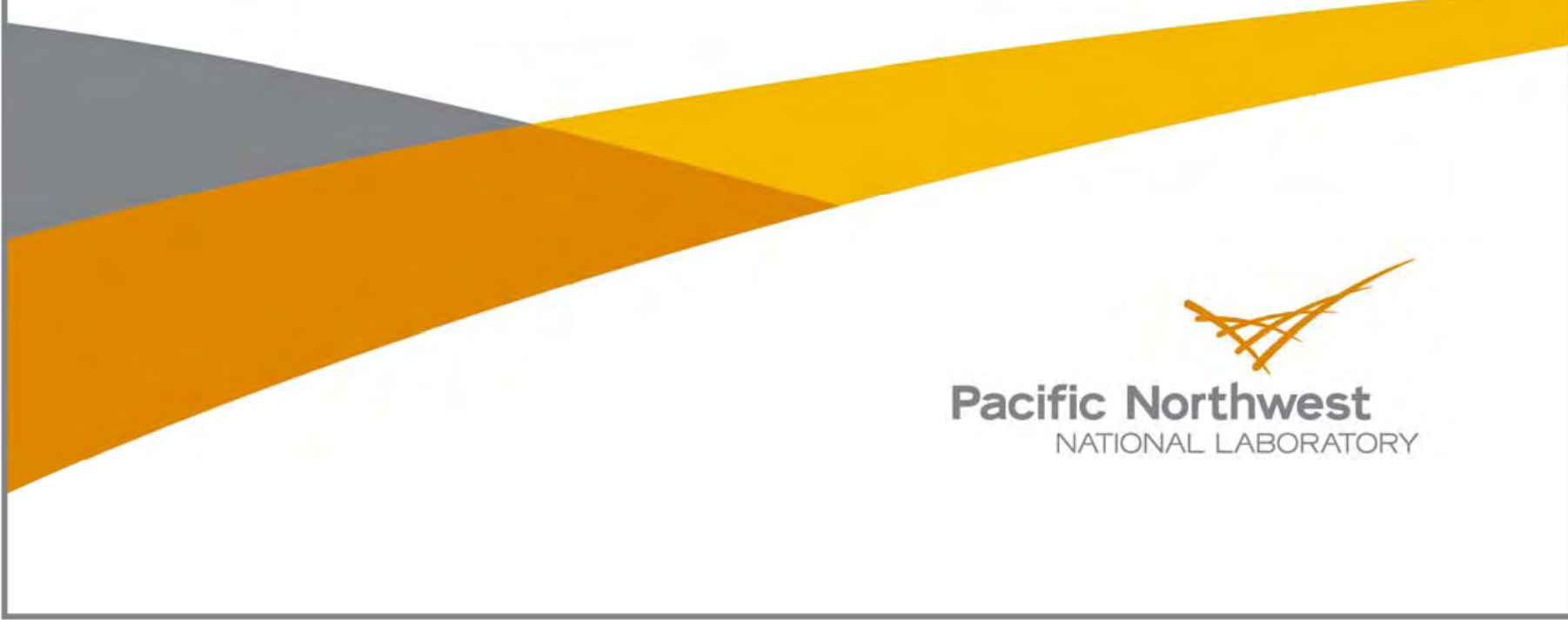




\title{
DISCLAIMER
}

This report was prepared as an account of work sponsored by an agency of the United States Government. Neither the United States Government nor any agency thereof, nor Battelle Memorial Institute, nor any of their employees, makes any warranty, express or implied, or assumes any legal liability or responsibility for the accuracy, completeness, or usefulness of any information, apparatus, product, or process disclosed, or represents that its use would not infringe privately owned rights. Reference herein to any specific commercial product, process, or service by trade name, trademark, manufacturer, or otherwise does not necessarily constitute or imply its endorsement, recommendation, or favoring by the United States Government or any agency thereof, or Battelle Memorial Institute. The views and opinions of authors expressed herein do not necessarily state or reflect those of the United States Government or any agency thereof.

\author{
PACIFIC NORTHWEST NATIONAL LABORATORY \\ operated by \\ BATTELLE \\ for the \\ UNITED STATES DEPARTMENT OF ENERGY \\ under Contract DE-AC05-76RL01830
}

Printed in the United States of America
Available to DOE and DOE contractors from the Office of Scientific and Technical Information,
P.O. Box 62, Oak Ridge, TN 37831-0062;
ph: (865) 576-8401
fax: (865) 576-5728
email: reports@adonis.osti.gov

\begin{abstract}
Available to the public from the National Technical Information Service, U.S. Department of Commerce, 5285 Port Royal Rd., Springfield, VA 22161 ph: (800) 553-6847 fax: (703) 605-6900

email: orders@ntis.fedworld.gov

online ordering: http://www.ntis.gov/ordering.htm
\end{abstract}

Ty This document was printed on recycled paper. 


\title{
Test Plan to Assess Fire Effects on the Function of an Engineered Surface Barrier
}

\author{
AL Ward \\ GT Berlin ${ }^{1}$ \\ JW Cammann ${ }^{2}$ \\ KD Leary ${ }^{3}$ \\ SO Link ${ }^{4}$ \\ ${ }^{1}$ Fluor Hanford, Richland, WA \\ 2 Fluor Government Group, Richland, WA \\ ${ }^{3}$ US DOE, Richland Operations Office, Richland, WA \\ ${ }^{4}$ Washington State University, Richland, WA
}

September 2008

Prepared for

the U.S. Department of Energy

under Contract DE-AC05-76RL01830

Pacific Northwest National Laboratory

Richland, Washington 99352 


\section{Executive Summary}

Wildfire is a frequent perturbation in shrub steppe ecosystems, altering the flora, fauna, atmosphere, and soil of these systems. Research on fire effects has focused mostly on natural ecosystems with essentially no attention on engineered systems like surface barriers. The scope of this project is to use a simulated wildfire to induce changes in an engineered surface barrier and document the effects on barrier performance. The main objective is to quantify the effects of burning and the resulting post-fire conditions on alterations in soil physical properties, hydrologic response, particularly the water balance, geochemical properties, and biological properties. A secondary objective is to use the lessons learned to maximize fire protection in the design of long-term monitoring systems based on electronic sensors.

A simulated wildfire will be initiated, controlled, and monitored at the prototype Hanford barrier in collaboration with the Hanford Fire Department during the fall of 2008. The north half of the barrier will be divided into nine $12 \times 12$ m plots, each of which will be randomly assigned a fuel load of $2 \mathrm{~kg} / \mathrm{m}^{2}$ or $4 \mathrm{~kg} / \mathrm{m}^{2}$. Each plot will be ignited around the perimeter and flames allowed to carry to the center. Any remaining unburned vegetation will be manually burned off using a drip torch. Progress of the fire and its effects will be monitored using point measurements of thermal, hydrologic, and biotic variables. Three measures of fire intensity will be used to characterize fire behavior, 1) flame height, 2) maximum temperature at three vertical profile levels, and 3) total duration of elevated temperature at these levels. Pre-burn plant information, including species diversity, plant height, and canopy diameter, will be measured on shrubs from the plots to be burned and from control plots at the McGee ranch. General assessments of shrub survival, recovery, and recruitment will be made after the fire. Near-surface soil samples will be collected pre- and post-burn to determine changes in the gravel content of the surface layer so as to quantify inflationary or deflationary responses to fire and to reveal the ability of the surface to resist post-fire erosive stresses. Measures of bulk density, water repellency, water retention, and hydraulic conductivity will be used to characterize changes in infiltration rates and water storage capacity following the fire. Samples will also be analyzed to quantify geochemical changes including changes in soil $\mathrm{pH}$, cation exchange capacity, specific surface area, and the concentration of macro nutrients (e.g., $\mathrm{N}$, $\mathrm{P}$, and $\mathrm{K}$ ), and other elements, such as $\mathrm{Na}, \mathrm{Mg}$, and $\mathrm{Ca}$, that are critical to the post-fire recovery revegetation. Soil $\mathrm{CO}_{2}$ emissions will be measured monthly for one year following the burn to document post-fire stimulation of carbon turnover and soil biogenic emissions. Surface and subsurface temperature measurements at and near monitoring installations will be used to document fire effects on electronic equipment.

The results of this study will be used to bridge the gaps in knowledge on the effects of fire on engineered ecosystems (e.g., surface barriers), particularly the hydrologic and biotic characteristics that govern the water and energy balance. These results will also support the development of practical fire management techniques for barriers that are compatible with wildfire suppression strategies.

Furthermore, lessons learned will be used to develop installation strategies needed to protect electronic monitoring equipment from the intense heat of fire and the potential damaging effects of smoke and fire extinguishing agents. Such information is needed to better understand long-term barrier performance under extreme conditions, especially if site maintenance and operational funding is lost for activities such as barrier revegetation. Given the unique performance baseline data collected to date at the Hanford Prototype Barrier site, DOE representation for this project will continue to seek appropriate funding to continue post-burn monitoring for at least the next five years. Available funding will be identified in budget guidance provided by DOE to the Plateau Remediation Contractor. 


\section{Pacific Northwest National Laboratory Approvals}

U.S. Department of Energy

Richland Operations Office:

Environmental Protection Agency:

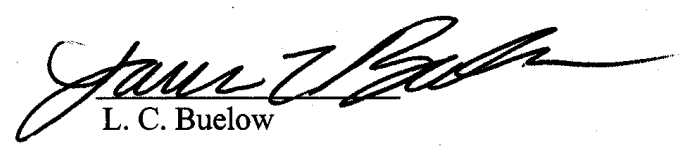

$\frac{\text { MalkD. Fresluly }}{\text { M. D. Freshley }}$

PNNL Manager for FH Projects:

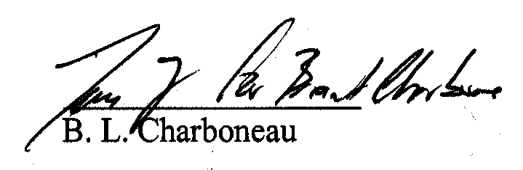

L. C. Buelow

\section{PNNL Manager for EH Projects:}

$\frac{9 / 25 / 08}{\text { Date }}$

$\frac{9 / 25 / 08}{\text { Date }}$

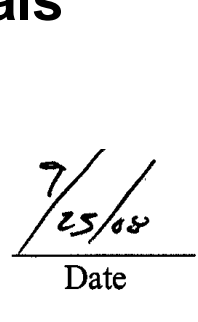




\title{
Acronyms and Abbreviations
}

\author{
CX Categorical Exclusion \\ CFR Code of Federal Regulations \\ CERCLA Comprehensive Environmental Response, Compensation, and Liability Act of 1980 \\ CRR Cultural Resource Review \\ DOE-RL U.S. Department of Energy/Richland Operations Office \\ DOE U.S. Department of Energy \\ ERT Electrical Resistance Tomography \\ ER Electrical Resistivity \\ ESA Endangered Species Act \\ ET Evapotranspiration \\ FGG Fluor Government Group \\ FH Fluor Hanford \\ FIRB Firing Boss \\ FLTF Field Lysimeter Test Facility \\ GPR Ground Penetrating Radar \\ HDU Heat Dissipation Units \\ HFD Hanford Fire Department \\ HMS Hanford Meteorological Station \\ RXI2 Ignition Specialist \\ IC Incident Commander \\ LAI Leaf Area Index \\ LCES Lookouts, Communications, Escape Routes, and Safety Zones \\ MOU Memorandum of Understanding \\ OU Operable Unit \\ PNNL Pacific Northwest National Laboratory \\ QA Quality Assurance \\ RAV Remote Aerial Vehicle \\ SBMS Standards-Based Management System \\ SOM Soil Organic Matter \\ TDR Time Domain Reflectometry \\ URMA Underground Radioactive Materials Area \\ USDA United States Department of Agriculture \\ WSU Washington State University \\ WDPT Water Drop Penetration Time
}




\section{Contents}

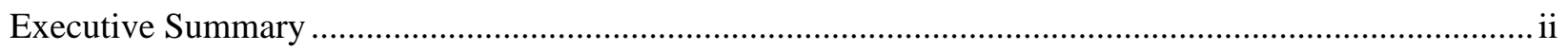

Pacific Northwest National Laboratory Approvals.............................................................................ii

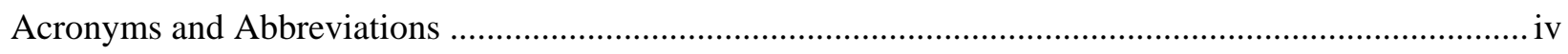

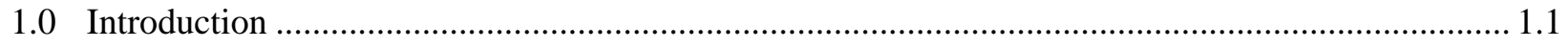

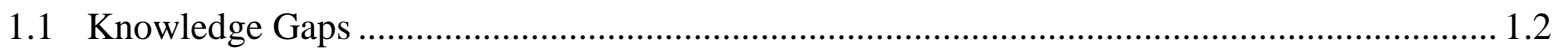

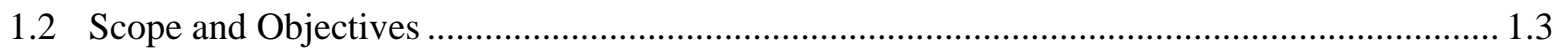

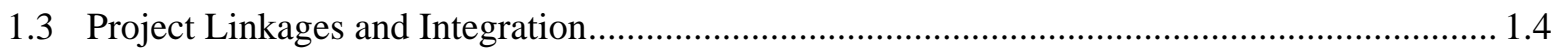

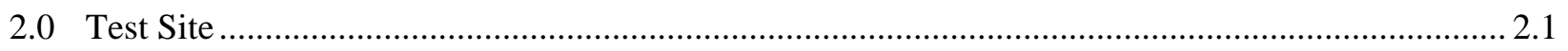

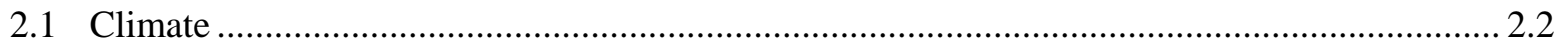

2.2 Soils and Vegetation................................................................................................... 2.2

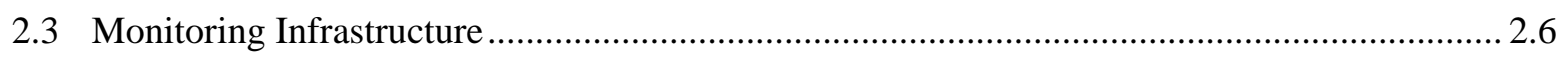

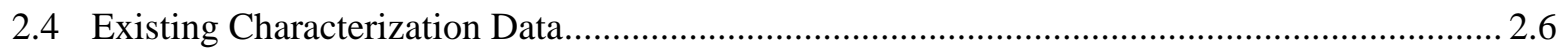

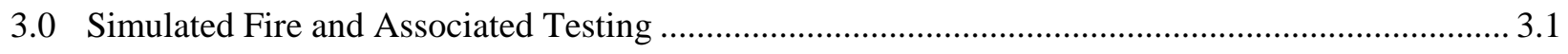

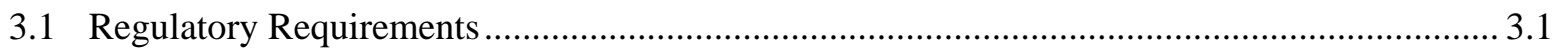

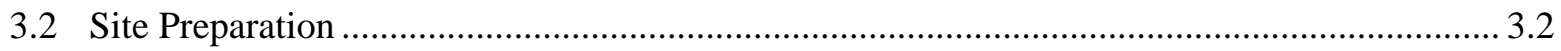

3.3 Pre- and Post-Fire Biological Monitoring .......................................................................... 3.5

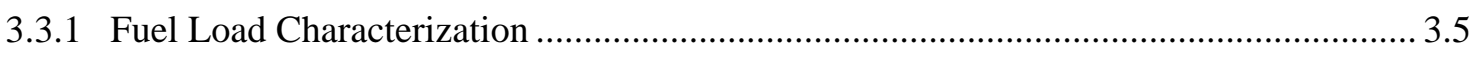

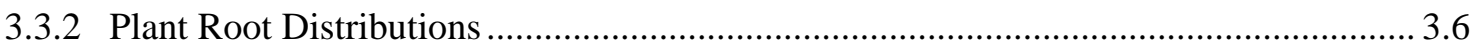

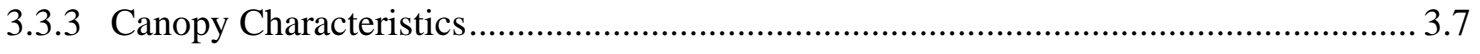

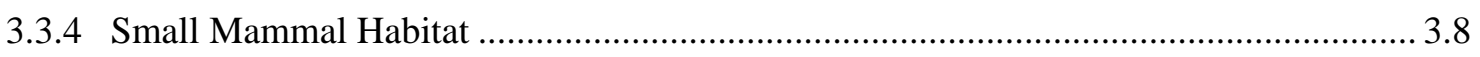

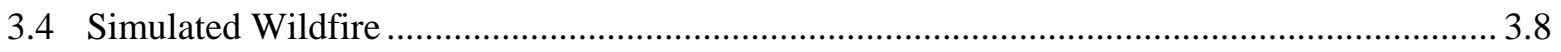

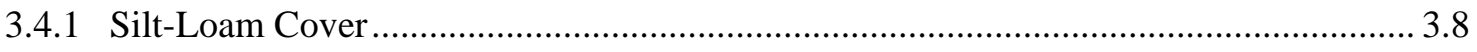

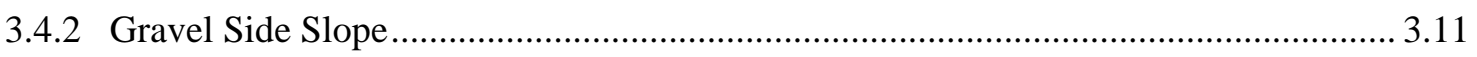

3.5 Fire Effects on Hydrophysical Properties ........................................................................ 3.11

3.5.1 Surface Layer Composition and Inflation/Deflation .................................................. 3.11

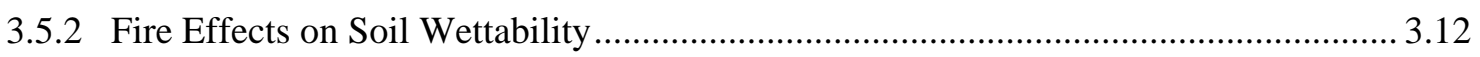

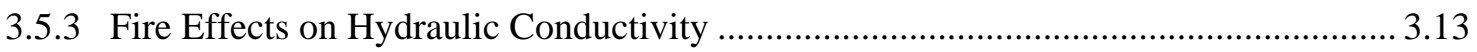

3.5.4 Fire Effects on Infiltration Rates and Runoff ........................................................... 3.13

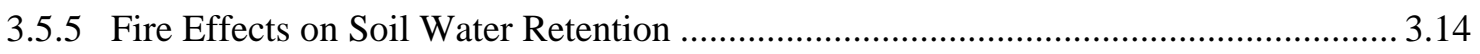

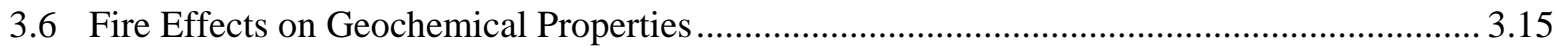

3.6.1 Fire Effects on Chemical Properties of Soil Extracts ................................................... 3.15

3.6.2 Fire Effects on Mineralogy and Soil Genesis............................................................. 3.16

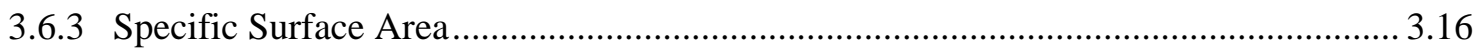

3.7 Post-fire Stimulation of Biogenic $\mathrm{CO}_{2}$ Emissions............................................................... 3.17

4.0 Data Collection, Management, Analysis, and Interpretation ....................................................... 4.1

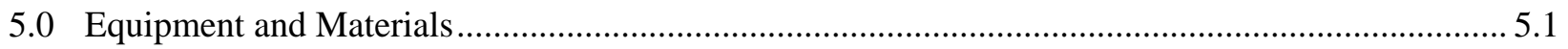




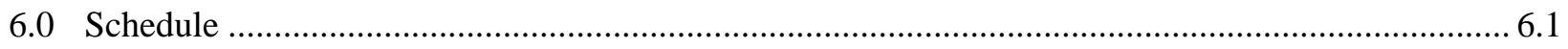

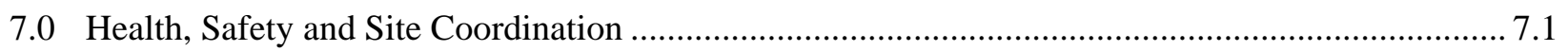

7.1.1 Prescribed Fire Organization................................................................................... 7.1

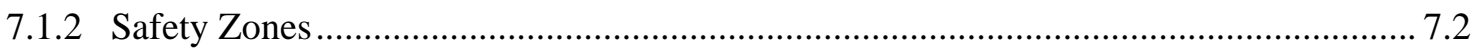

7.1.3 Contingency Plan for Escaped Fire ........................................................................ 7.2

7.1.4 Barrier Burn Control and Tactics ........................................................................... 7.2

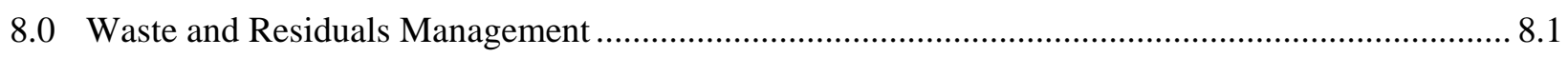

8.1 Management Activity A - Solid Waste Management Plan for Soil Analysis.......................... 8.1

8.2 Management Activity A - Solid Waste Management Plan for Plant Samples ........................ 8.1

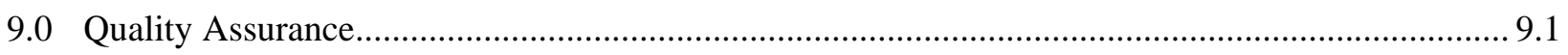

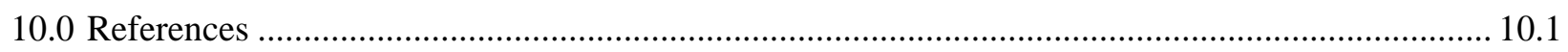

Appendix A 2008 Prescribed Burn Permit .......................................................................................... A.1

Appendix B Biological Resource Review ……..................................................................................

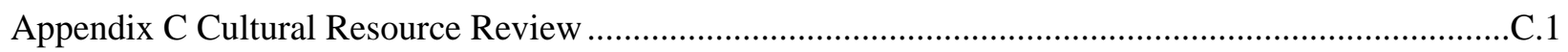

Appendix D Site Access and Conduct Requirements for the Barrier ................................................... D.1 


\section{Figures}

Figure 2.1. Aerial View of the Prototype Hanford Barrier and Surrounding Facilities Looking Southwest from the Northeast Corner of the Site

Figure 2.2. Schematic of the Vegetated, Multilayered Capillary Barrier Showing the Layer Sequence. This cross section includes the rip rap side slope on the eastern side.

Figure 2.3. South Facing Aerial View of the Barrier Showing Distribution of Plants on the Surface and Side slopes. Note the relatively sparse vegetation in the northwest (lower right) quadrant of the surface.

Figure 2.4. Photograph of the Barrier's Surface Showing the Dominant Sagebrush (Artemisia tridentate) in 2007. Note the tumbleweed lodged between the Sagebrush plants.

Figure 2.5. Mean Cover on Formerly Irrigated (North) Half of the Barrier. Error bars of one standard error of the mean. Different letters indicate significant differences.

Figure 2.6. Temporal Variation in the Number of Annual/Biennials and Perennial Species Including Total Species on the Barrier.

Figure 2.7. Plan View of the Barrier Showing the Layout of the 12 Surface Soil Plots (1W to $6 \mathrm{~W}$ and $1 \mathrm{E}$ to 6E) and Horizontal Neutron Access Tubes (AA-Above Asphalt; BA-Below Asphalt) 2.7

Figure 3.1. Schematic Plan View of the Barrier's Surface Showing Monitoring Stations, the Runoff Plot, the $3 \times 3 \mathrm{M}$ Grid, and the Nine $12 \times 12 \mathrm{M}$ Plots to Be Used for Comparing Fuel Loads on Fire Intensity.

Figure 3.2. Photographs of the Barrier Surface and Gravel Side Slope Showing Examples of Monitoring Infrastructure on the Surface That Will Need Protection From the Simulated Fire.

Figure 3.3. Photograph of Thermocouple Towers to Be Used for Monitoring Temperature at Different Elevations During the Simulated Fire. A tower with one thermocouple is shown in the foreground.

Figure 3.4. Photographs of the Barrier's Surface (a) Sparse Vegetation on the Surface Suggesting Need for Increased Fuel Load to Ensure Realistic Fire Characteristics, Some Salsola Kali (Tumbleweed) is Already Logged Among Sagebrush Plants, and (b) The Rip Rap Side Slope of the Barrier Showing an Accumulation of Tumbleweed. Dead sagebrush and tumbleweed will be imported to the barrier surface to increase the fuel load.

Figure 3.5. Schematic Plan View of the Barrier's Surface Showing Proposed Burn Area on the Gravel Side Slope and Silt-loam Surface. A $3 \mathrm{~m}$ wide line of fire retardant foam will be used to protect the south portion of the barrier during the burn.

Figure 7.1. Prescribed Fire Organization

\section{Tables}

Table 4.1. Summary of Tasks, Responsibilities, Data Types, and Data Collection Methods

Table 5.1. Required Equipment and Materials and Estimated Costs for the Fire-effects Field Test

Table 6.1. Schedule for Major Barrier Burn Activities Through End of FY 2008

Table 6.2. Schedule for Major Barrier Burn Activities Through End of FY 2008 (2 pages) 



\subsection{Introduction}

As one of the last remedial alternatives to remove, treat and dispose for waste sites, many DOE sites are increasing their reliance on engineered surface barriers for long-term isolation of wastes left in place. At Hanford alone, upwards of 300 barriers covering over 1000 acres are being considered. The placement of engineered surface barriers over waste sites is anticipated to control infiltration and reduce the leaching of mobile vadose zone contaminants of concern into groundwater (DOE 2005a). Over 10 years of data from the prototype Hanford barrier (known as the barrier from here on), constructed in 1994, show that store and release barriers can exceed established performance criteria when adequately designed and constructed (DOE 1999, Ward et al. 2005a, 2006, 2007). Nonetheless, some uncertainties remain about barrier technology in relation to long-term performance, particularly in relation to the effects of wildfire on short- and long-term hydrologic function. Much of the uncertainty could be reduced through a controlled burn of an engineered barrier with a fire designed to simulate the temperature and duration of a large-scale range fire.

A considerable amount of research has been conducted on fire effects on the flora, fauna, atmosphere, and soil in natural ecosystems (Doerr and Cerdà, 2005). The effects of fire on ecosystems are complex and range from the reduction, or even elimination, of above-ground biomass to impacts on soil physical, chemical, and microbial mediated processes (FEIS 2007). In general, these studies show that burning and the resulting post-fire conditions can alter the soil physically (e.g., aggregate stability, pore size distribution, water repellency, and runoff response), geochemically (e.g., mineralogy, $\mathrm{pH}$, nutrient availability, and C:N ratios), and biological (e.g., biomass productivity, vegetative re-sprouting, plant species recruitment, microbial composition, carbon sequestration, and animal habitat) properties.

Most of these studies show that the degree of damage sustained by plants is proportional to the intensity and duration of the fire that affects the growing points. Some positive effects have been reported. For example, communities dominated by big sagebrush often show a rapid increase in forbs compared to pre-burn production with three years post-fire (FEIS, 2007). However, there can also be significant negative effects. The destruction of surface litter and vegetation by fire removes the protection of the surface soil from the impact of raindrops that promotes sealing and increases runoff (Powers et al. 1990, Neary et al. 1999). In most soils, primary soil particles (e.g., sand, silt, and clay) are aggregated together into structural units by soil organic matter (SOM). Loss of SOM and the breakdown of structure results in a collapse of macropores (i.e., pores $>600 \mu \mathrm{m}$ diameter) that function to promote water infiltration, consequently surface runoff increases.

Another cause of increased runoff is fire-induced water repellency (DeBano 1981). Water repellency typically develops in a discreet layer of soil parallel to the surface where hydrophobic organic compounds coat soil aggregates or minerals. This condition is often associated with high-intensity fires $\left(>176^{\circ} \mathrm{C}\right)$ and certain litter types but tend to disappear at soil temperatures above $288^{\circ} \mathrm{C}$ (DeBano et al. 1976, DeBano, 1981). In water-repellant soils, water is prevented from wetting aggregates causing a decrease in infiltration. The net effect of increased runoff is the erosion of nutrient-rich ash, the lost of fine-textured sediments, and the reduction in soil-moisture that may ultimately lead to desiccation of the root zone. Reduced moisture may restrict the activities of microbes involved in biogeochemical cycling and may prevent their recovery. Reduced moisture can also create a negative feedback on nutrient cycling by inhibiting recolonization of plants that stabilize soils, resulting in increased erosion of nutrient-rich sediments from the near surface. In ecosystems where nutrients are already limiting, soil and nutrient loss 
could limit the re-establishment of desirable plant communities that in turn could impact the hydrologic function of the soil-plant system. At arid sites, runoff and sediment loss are compounded by the occurrence of high intensity rainfall events; not through seed loss or reduced germination and emergence, but from seedlings being buried by sediment that is partially unearthed due to litter losses (Rinne 1996, Luís et al. 2005).

Soil geochemical properties may also be altered by fire, depending on the fire intensity. Fires with high fuel loads typically result in complete combustion of vegetation whereas the low loads result in only partial combustion (De Marco et al. 2005). Both high and low fuel load fires have been shown to lead to an increases in SOM, although only part of the accumulated SOM is mineralized in the short term ( $\leq$ 3 months). De Marco et al. (2005) observed an increase in the total and available elements (K, Mg, $\mathrm{Na}$, $\mathrm{Mn}, \mathrm{Fe}, \mathrm{Cu}, \mathrm{Pb}$, and $\mathrm{Cd}$ ), trace elements, microbial biomass, and $q \mathrm{CO}_{2}$ on burned soils. Increases in soil $\mathrm{pH}$ and cation nutrients immediately following burning have been reported with the effects persisting for several years (Covington et al. 1991, Marion et al. 1991, Bauhus et al. 1993).

Clay minerals are typically not altered during fire because of their low content in surface soil horizons, the high temperatures $\left(>460^{\circ} \mathrm{C}\right)$ needed to produce a loss of $\mathrm{OH}^{-}$groups (Giovannini et al. 1988), or those temperatures $\left(>980^{\circ} \mathrm{C}\right)$ needed to cause irreversible changes in water of hydration (DeBano et al. 1977). However, other minerals have been shown to undergo alteration during highintensity fires. Goforth et al. (2005) observed significant differences in soil properties due to thermal alteration that were correlated with fuel densities in forest fires. White ash, composed almost entirely of calcite, covered about $25 \%$ of the soil surface, especially in locations where large fuel sources (e.g., logs, branches, and exfoliated oak bark) had thoroughly combusted. Combustion of coarse fuel (e.g., logs and large branches) also reddened the underlying yellow-brown soil to depths of $60 \mathrm{~mm}$ (average $8 \mathrm{~mm}$ ) over approximately $1 \%-12 \%$ of the land surface. The reddened soils showed magnetic susceptibilities that were three to seven times greater than surrounding soils, within the burn area, that didn't undergo a color change indicating a thermal production of maghemite $\left(\mathrm{Fe}_{2} \mathrm{O}_{3}, \gamma-\mathrm{Fe}_{2} \mathrm{O}_{3}\right)$.

All of the effects described above depend on fire severity and intensity, which in turn are controlled by a variety of other factors. Fire produces a spectrum of severities that depends on the interactions of burning, intensity, duration, fuel loading (i.e., live and dead materials), combustion type and degree of oxidation, vegetation type, fire climate, slope, topography, soil texture and moisture, SOM content, burn history of the site (time since it last burned), and the area burned. Thus, the effects of fire on a mixed shrub/grass ecosystem can cover a wide range of severity. The combination of fire and high intensity rainfall events typical of desert environments may have a persistent effect on vegetation recovery, and may cause further degradation, which may eventually become irreversible. Such an occurrence on engineered barriers could have a negative impact on long-term performance. Essentially all of our estimates of long-term performance are based on model predictions using short-term data. None of these models is capable of simulating the effects of fire. A controlled burn of the barrier with a fire that simulates the temperature and duration of a large-scale range fire would provide the necessary data.

\subsection{Knowledge Gaps}

A large number of studies has been published on the effects of wild and prescribed fire in forest ecosystems (Goforth et al. 2005, Hubbert and Oriol, 2005), shrublands (Luís et al. 2005), and grasslands (Úbeda et al. 2005). Many of these studies have documented fire characteristics under different fuel 
loadings and environmental conditions. They have investigated the consequences of differing fire frequencies, fire intensities, and fire severities in natural ecosystems. Despite the strong coupling of the physical, chemical, and biotic effects, many of the fire-induced alterations have been studied in isolation by researchers in separate disciplines. Information was usually obtained over a limited range of fire severities and/or ecosystem types making it difficult to extrapolate to other systems. It is therefore important that data on the key physical, chemical, and biological processes controlling barrier ecosystem performance and sustainability be documented. Another large source of uncertainty relates to long-term monitoring and design of monitoring systems. Essentially all of the automated monitoring systems rely on electronic sensors, mostly powered by deep cycle batteries and solar cells, but little consideration has been given to fire protection systems or mechanisms in their selection or installation. Installation strategies are needed to protect electronic equipment from the intense heat of fire and the potential damaging effects of smoke and fire extinguishing agents.

The literature suggests that fire produces a spectrum of severities depending on intensity, duration, fuel loading, vegetation type, fire climate, soil type, antecedent soil moisture conditions, and the area burned. Prescribed burns typically attempt to leave sites with the surface condition of a low severity burn. The prototype barrier is an engineered system that was artificially revegetated at a density atypical of natural shrub steppe ecosystems and the response of such a system to fire remains largely unknown. It is known that most fires, independent of severity and intensity, can cause top kill in most plant species. However, a number of species can survive fire and initiate post-fire re-growth from subsurface tissue making them attractive for revegetation of engineered barriers. Such species need to be identified for the type of barriers being considered for Hanford conditions. Information regarding fire impacts on engineered barriers is important because information regarding plant invasion/succession on a post-fire barrier coupled with post closure institutional control is critical to barrier acceptance by stakeholders and regulators.

The preceding review has identified a number of knowledge gaps related to barrier response to fire. Even in ecosystems that have been studied extensively, the ability to describe or predict impacts of fire appears limited due to inconsistent data. The proposed study is intended to bridge the gaps in knowledge on the effects of fire in engineered ecosystems (e.g., barriers), particularly the impacts on barrier performance in mitigating or eliminating percolation into underlying waste.

\subsection{Scope and Objectives}

The scope of the project is to use a simulated wildfire to induce changes in the ecology, hydrophysical, and geochemical properties of the barrier, document the response, and draw inferences about fire behavior under different fuel loadings, fire intensities, and post-fire conditions. This scope represents the first of three phases being considered for the development of a robust, long-term monitoring strategy for engineered barriers. The proposed phases are:

- Phase I - characterize barrier condition and performance before and after a simulated fire.

- Phase II - following reestablishment of vegetation, investigate the feasibility of using airborne (e.g., helicopter or remote aerial vehicle) monitoring technologies (e.g., Light Detection and Ranging, hyperspectral imaging, synthetic aperture radar, electromagnetic induction) to characterize the surface

- Phase III - investigate the feasibility of using remote sensing for monitoring barrier performance. 
The overall objective of Phase I (the focus of this test plan) is to evaluate the short- and long-term impacts of fire on barrier performance and the infrastructure currently being used for monitoring performance. More specifically, this study will investigate and quantify the effects of fire and the resulting post-fire conditions on:

- Alterations in soil physical (e.g., aggregate stability, pore size distribution, water repellency, wind and water erosion, infiltration capacity, water storage capacity, and macroporosity) properties.

- Alterations in geochemical (e.g., mineralogy, pH, nutrient availability, and C:N ratios) properties.

- Alterations in biological properties (e.g., evapotranspiration, biomass productivity, microbial composition, carbon sequestration, and plant and animal habitat) properties and post-fire colonization by plants and animals.

- The design, installation, and function of long-term monitoring systems that rely on electronic sensors so as to maximize fire protection.

It is anticipated that the results of this study will contribute to bridging the gaps in knowledge of the effects of fire in engineered barriers that are being considered for use in environmental remediation. Such information is needed to better understand long-term barrier performance under extreme conditions, especially if site maintenance and operational funding is lost for activities such as barrier revegetation. These data will also support the development of installation strategies needed to protect electronic equipment from the intense heat of fire and the potential damaging effects of smoke and fire extinguishing agents. This study may also prove useful to other resource managers and other researchers interested in the use of prescribed fire as a management tool. More importantly, the results will also support the development of workable fire management techniques for barriers that are compatible with wildfire suppression strategies, especially if prescribed fire is needed to control undesirable invasive species.

\subsection{Project Linkages and Integration}

Remedial actions are being planned for waste sites in the 200-UW-1 Operable Unit (OU) to identify preferred remedial alternatives for 33 waste sites in the OU (DOE 2005a). Three engineered surface barriers have been proposed to cover 5 of the waste sites including the 216-U-8, 216-U-12, 216-U-1, and 216-U-2 Cribs, and the 214-U-361 Settling Tank. The placement of engineered surface barriers over waste sites will control the amount of precipitation that can infiltrate thereby reducing remobilization of vadose zone contaminants of concern into groundwater (DOE 2005a). The preferred surface barrier technology for the site is the evapotranspiration (ET) type barrier that relies on the water-holding capacity of a fine-textured top soil to store water during the winter followed by the release of this water by evaporation from the near-surface, and plant transpiration from within the root zone (DOE 2005b). Precipitation is allowed to infiltrate at the surface, where it is retained in the soil until ET processes remove the water back to the atmosphere. Such store and release designs are particularly suitable for areas with semiarid and arid climates, such as the Hanford Site, but depend heavily on a robust and sustained plant community on the surface to function properly.

The barrier design process is based almost entirely on numerical modeling (Ward et al. 2005, White and Ward, 2005, Ward 2007). Numerical models are used to simulate water balance mechanisms and provide estimates of moisture movement through representative full-scale surface barriers. Numerical 
modeling can address the volume of different soil materials needed, based on optimized thickness of the soil layer, and the ideal plant density, based on simulated ET rates. These results have been validated using short-term data collected at test facilities like the barrier and the field lysimeter test facility. However, these models cannot predict the effects of long-term changes induced by fire beyond the assumption of a bare surface. This is because fire affects the entire ecosystem and the extent of fireinduced alterations in engineered ecosystems, especially on the soil properties controlling the water balance, are essentially unknown. Such data are needed to support defensible engineering barrier designs and to aid in the development of workable fire management strategies (e.g., fire protection for monitoring equipment) for long-lived barriers.

The simulated burn will involve multiple organizations including Hanford Fire Department (HFD), the Pacific Northwest National Laboratory (PNNL), Fluor Hanford (FH), Fluor Government Group (FGG), and Washington State University (WSU) personnel on foot and in vehicles. A memorandum of understanding (MOU) has been established between Fluor Hanford (FH) organizations supporting the Barrier Burn Project (i.e., Soil \& Groundwater Remediation Project and Central Plateau Surveillance \& Maintenance). The MOU speaks to interfaces with others (i.e., PNNL, WSU, and the Hanford Fire Department) in terms of roles and responsibilities. The FH interfaces with PNNL and WSU are governed by Contract Release 27647-168, Amendment 4, in accordance with the approved Test Plan. These organizations will work closely to confirm the suitability of barrier burn conditions (i.e., fuel load, wind speed/direction, fire-breaks, safety precautions, viewing/staging areas, etc.), to initiate and control the burn on the northern half of the barrier, and to ensure that the burn objectives are met in a safe manner. 



\subsection{Test Site}

The prototype Hanford barrier was constructed in 1994 over and to the north of the 216-B-57 waste crib in the former 200-BP-1 (now known as the 200-PW-5) Operable Unit (DOE 1997). This OU is located in the 200 East Area of the Hanford Site in the B-BX-BY complex, northwest of the BY tank farm, north of the B-trenches and southwest of the BY cribs. Figure 2.1 shows a northeasterly to southwesterly aerial view of the barrier and surrounding facilities. The 216-B-57 Crib within the 200-PW-5 operable unit received storage condensate waste from the 241-BY Tank Farm between February, 1968 and June, 1973. An in-tank solidification process created waste by heating, collecting, and condensing the evaporants within the 241-BY Tank Farm, and discharging the waste underground in the 216-B-57 Crib.

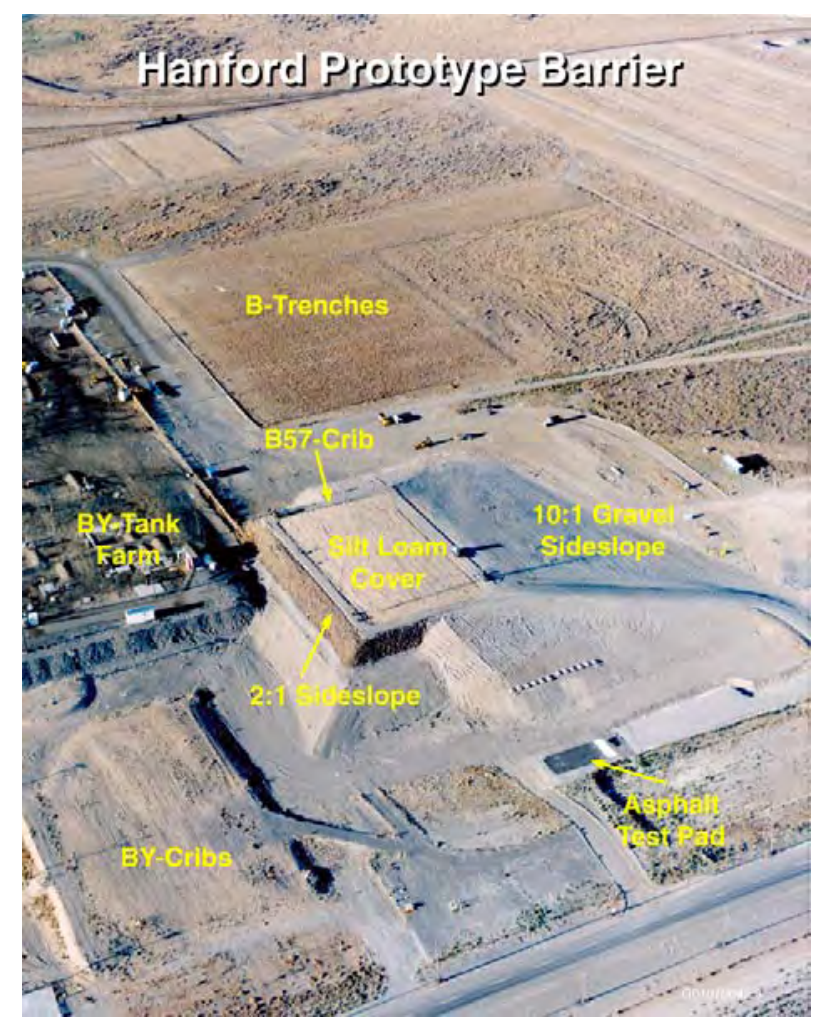

Figure 2.1. Aerial View of the Prototype Hanford Barrier and Surrounding Facilities Looking Southwest from the Northeast Corner of the Site

The BY and BX tank farms are located immediately to the east and southeast of the prototype barrier. Staff should be aware that radiological hazards potentially exist at the test site. The prototype barrier is designated as an Underground Radioactive Materials Area (URMA). An URMA is established to indicate the presence of underground items that contain radioactive materials, such as the underlying contaminated crib (B-57) at the barrier. The current posting includes a special instruction to consult with the radiological control organization before digging. Since more than $5 \mathrm{~m}$ of clean material was placed to construct the surface barrier, the general requirement applies only to digging below a 2-m depth within the perimeter of the designated area. For any excavation 2 meters in depth at the designated area, the Site Operations Manager must be contacted at least 72 hours ahead of the planned activity date. The site is also subject to the transport of radiological materials via wind or biological vectors. Under the current 
posting, the site is exempt from the general entry and exit requirements provided individual doses do not exceed 100 mrem in a year. Observations of radiological exposure over the past decade years show no exposure above background in workers that routinely work at the barrier site.

\subsection{Climate}

The climate is typical of the Hanford Site, which is arid with cool, wet winters and hot, dry summers. Precipitation at the Hanford Meteorological Station (HMS), located about $5 \mathrm{~km}$ west of the test site, has averaged $174 \mathrm{~mm}$ (6.85 in.) yr since 1946. Nearly half of the precipitation normally comes in the winter (November through February). Average monthly temperature ranges from $-1.5^{\circ} \mathrm{C}$ in January to $25^{\circ} \mathrm{C}$ in July. Humidity ranges from $75 \%$ in winter to $35 \%$ or less in the summer.

\subsection{Soils and Vegetation}

The barrier is a vegetated, multilayered barrier based on the capillary break concept (Figure 2.2). A layer of coarse material is placed directly below finer-textured soil. The fine-soil layer acts as a medium in which moisture is stored until the processes of evaporation (E) and plant transpiration (T) can recycle any excess water back to the atmosphere. In other words, the top $2 \mathrm{~m}$ of silt loam functions as an ET barrier. The fine-soil layer also provides a rooting medium to support plants that are necessary for transpiration to take place.

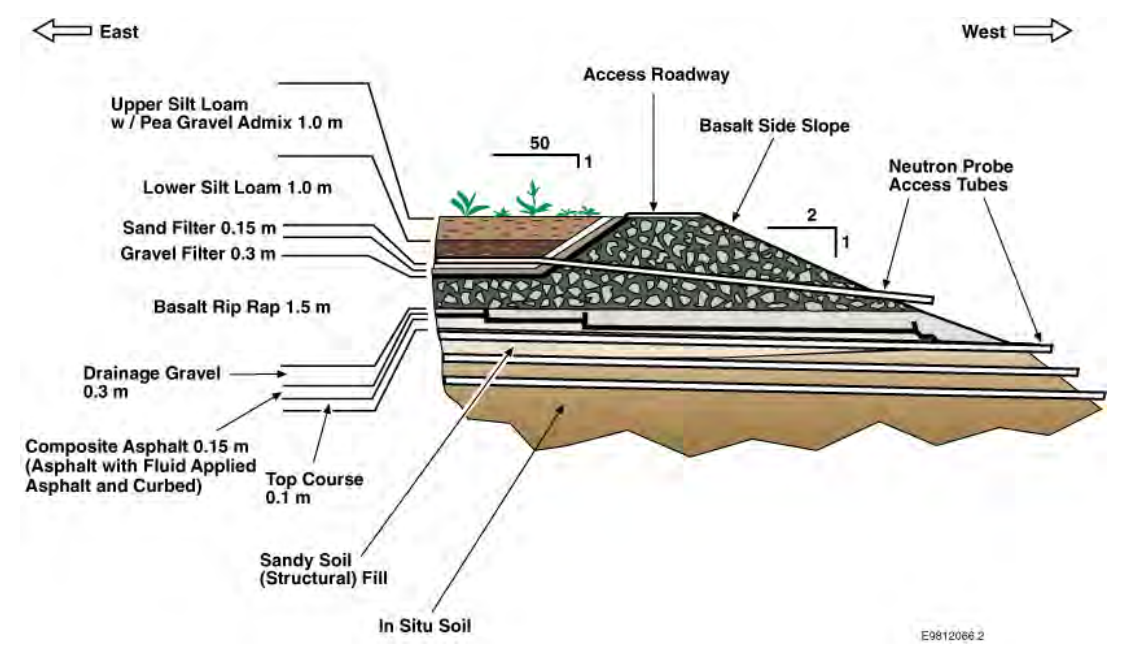

Figure 2.2. Schematic of the Vegetated, Multilayered Capillary Barrier Showing the Layer Sequence. This cross section includes the rip rap side slope on the eastern side.

The gravel admix comprising the surface reduces erosion due to wind and water. The coarser materials that are placed directly below the fine soil layers prevent the finer soils from filtering into the coarser materials and create a capillary break that inhibits the downward percolation of water through the barrier.

The basalt riprap sequence controls bio-intrusion by discouraging burrowing animals and creating a low moisture layer to mitigate or prevent root penetration. A low-permeability asphalt layer, placed in the barrier profile below the capillary break and the bio-intrusion layers, diverts any water that passes the capillary break away from the waste zone, and limits the upward movement of noxious gases from the waste zone. 
The native vegetation at the site was originally a mixture of sagebrush, tumble mustard (Sisymbrium altissimum), cheatgrass (Bromus tectorum), Sandberg's bluegrass (Poa secunda), and bulbous bluegrass (Poa bulbosa). Tumble mustard is a summer annual species with a rooting depth of $1 \mathrm{~m}$ or greater. Cheatgrass is a winter annual species with roots to a depth of around $0.75 \mathrm{~m}$. Sandberg's bluegrass is a native perennial bunchgrass with roots to $0.45 \mathrm{~m}$, while bulbous bluegrass is a non-native biennial grass with roots to $0.25 \mathrm{~m}$. Surveys of vegetation on the barrier and side slopes have been conducted in the spring and summer months for the last several years (Ward et al. 2007). Variables typically measured include shrub height and canopy dimensions as well as cover of 'grass, shrubs, forbs, litter, soil, and soil cryptogams. The most recent survey was conducted between June, 14 and August 18, 2007 (Ward et al. 2007).

Figure 2.3 is a south-facing aerial view of the barrier showing the current distribution of plants on the surface and side slopes. Note the relatively sparse vegetation in the northeast (lower right) quadrant of the surface. Sagebrush dominates the shrub cover of the barrier (Figure 2.4). In contrast, Rabbitbrush is quite sparse on the barrier surface, with relatively few plants in either treatment (formerly-irrigated, and non-irrigated) area. These were found mostly near the edges of the surface. A cryptogamic crust is well developed and now covers about $33.1 \%$ in the formerly irrigated (north) portion and $37.3 \%$ in the nonirrigated (south) portion. Comparisons of cover types within each half of the barrier were made in FY 2007 using midpoints of cover classes to compute means. The mean cover classes for the formerly irrigated (north) portion of the silt-loam plots to be burned is shown in Figure 2.5. On the north side of the barrier, grass cover was not zero but significantly less than shrub and other cover classes (Figure 2.5). Soil cryptogam cover was the same as soil cover.

Figure 2.6 compares the total number of annual and perennial species on the barrier surface from 1995 to 2007. The species richness of the surface has decreased from a high of 35 species in 1997, the third year after planting, to only 12 in 2007. Only seven of 14 species present in 2004 were present in 2007. Of the five new species on the surface in 2007, Centaurea diffusa has never been present while the other four have been observed in the past (Ward et al. 2007). The dominance of $A$. tridentata on the surface may likely contribute to continued reductions in species richness on the surface. Many of the species in 2007 were represented by only a few individuals and some of these were only found on the edges of the surface where there is less competition from $A$. tridentata. The reduction in the number of species on the surface is partly caused by the very high cover of A. tridentata. Artemisia tridentata was by far the most common plant on the surface and comprises almost a monoculture. Ward et al. (2007) suggested that there is some risk in this condition. If the shrubs were to die in a pathological event or if the area were to burn, then it does not seem like other vegetation would immediately occupy new available space on the surface and it is possible that the function of the barrier could be compromised. With few plants it is possible that water 


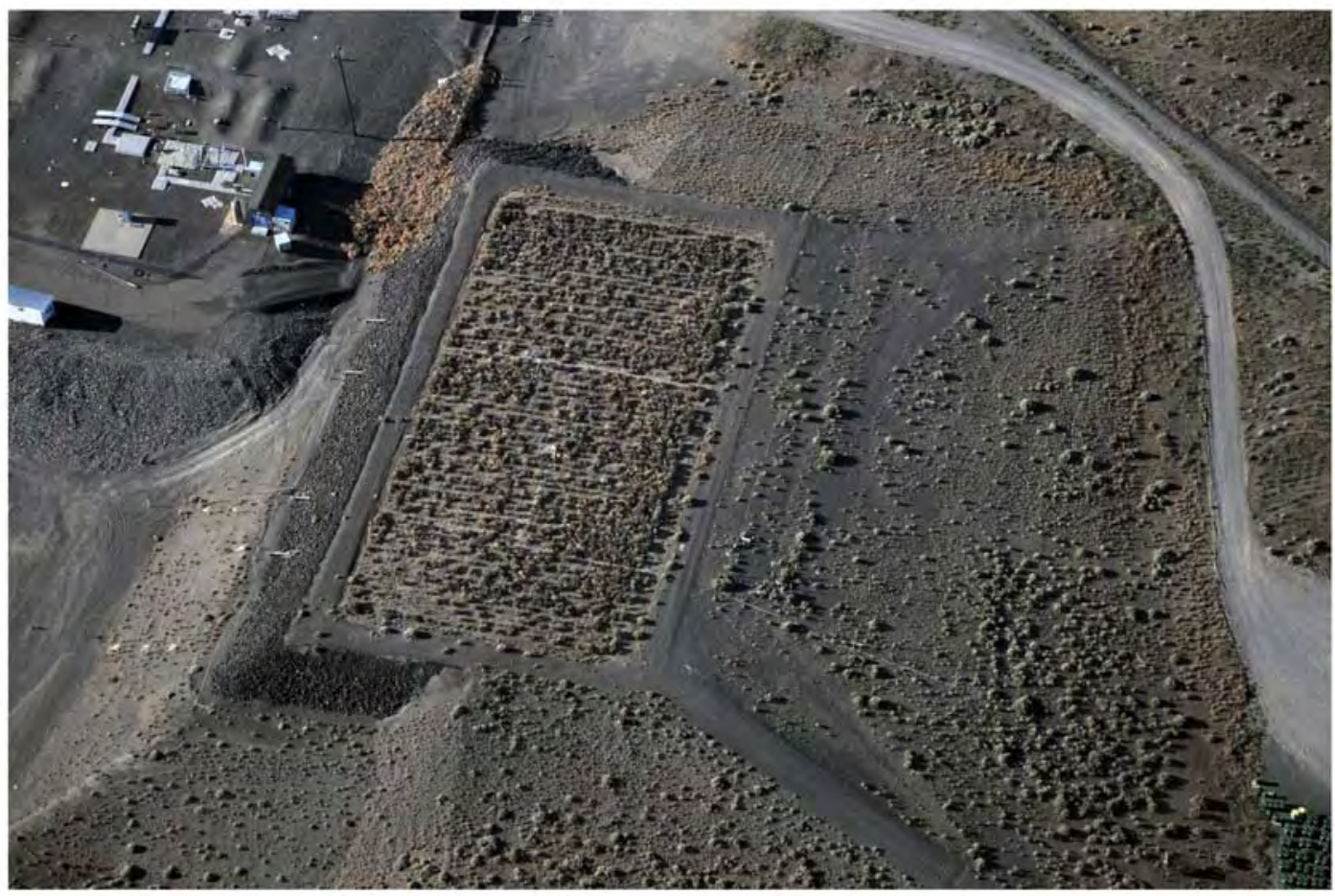

Figure 2.3. South Facing Aerial View of the Barrier Showing Distribution of Plants on the Surface and Side slopes. Note the relatively sparse vegetation in the northwest (lower right) quadrant of the surface.

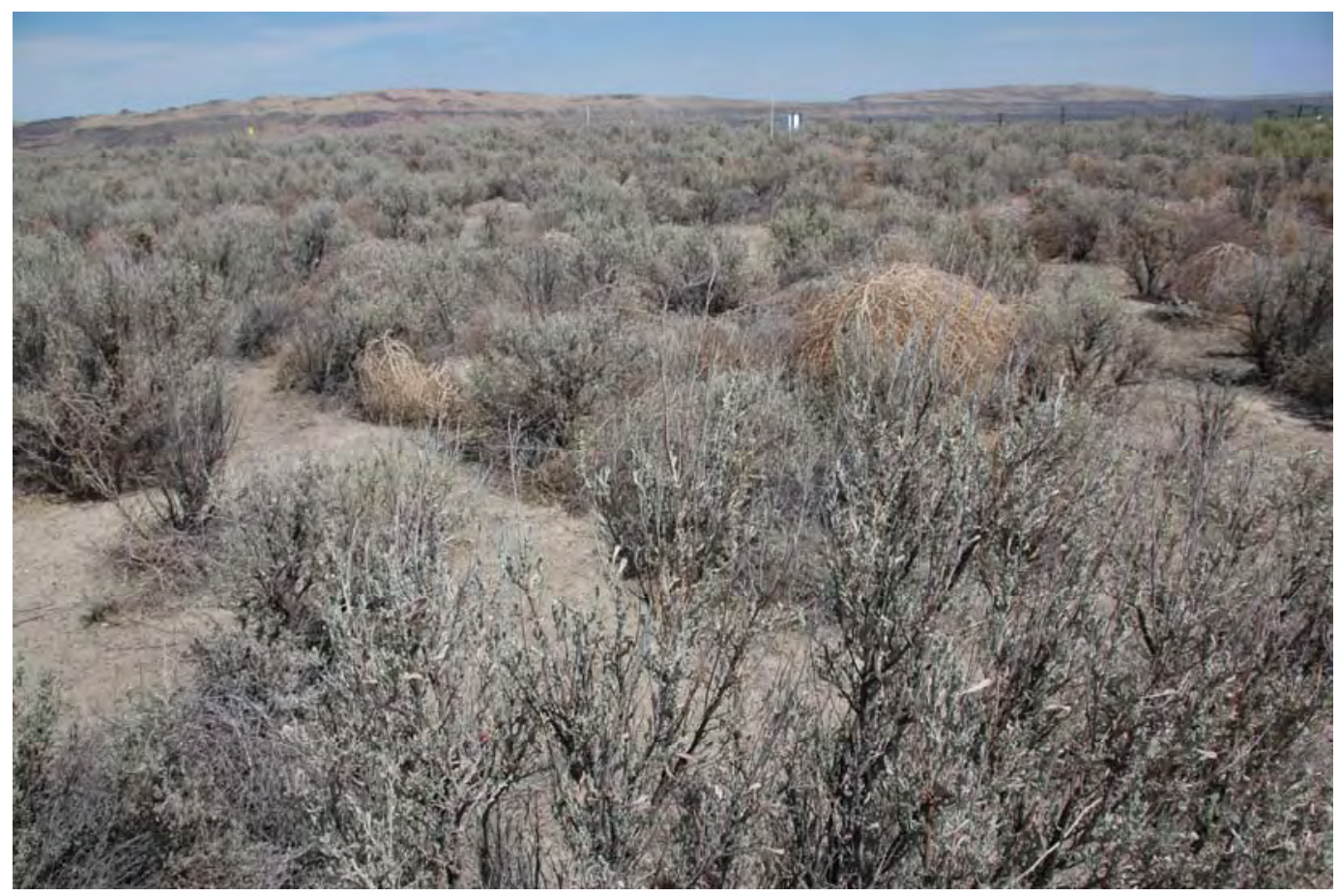

Figure 2.4. Photograph of the Barrier's Surface Showing the Dominant Sagebrush (Artemisia tridentate) in 2007. Note the tumbleweed lodged between the Sagebrush plants. 


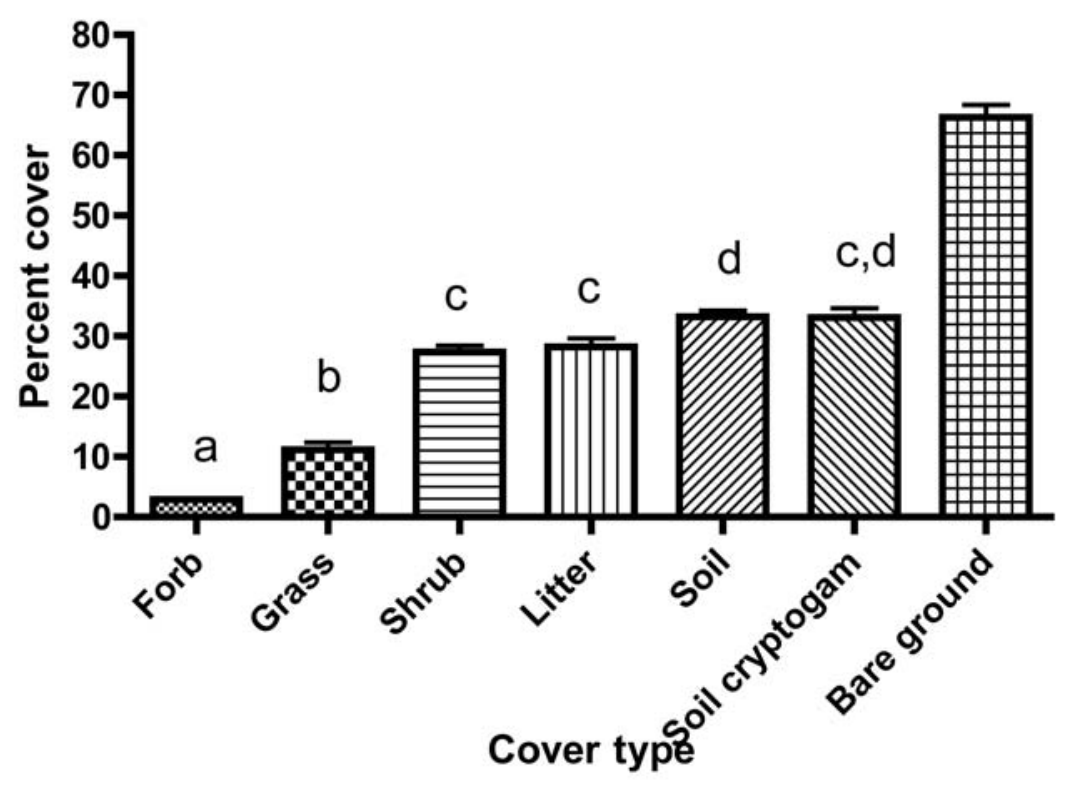

Figure 2.5. Mean Cover on Formerly Irrigated (North) Half of the Barrier. Error bars of one standard error of the mean. Different letters indicate significant differences.

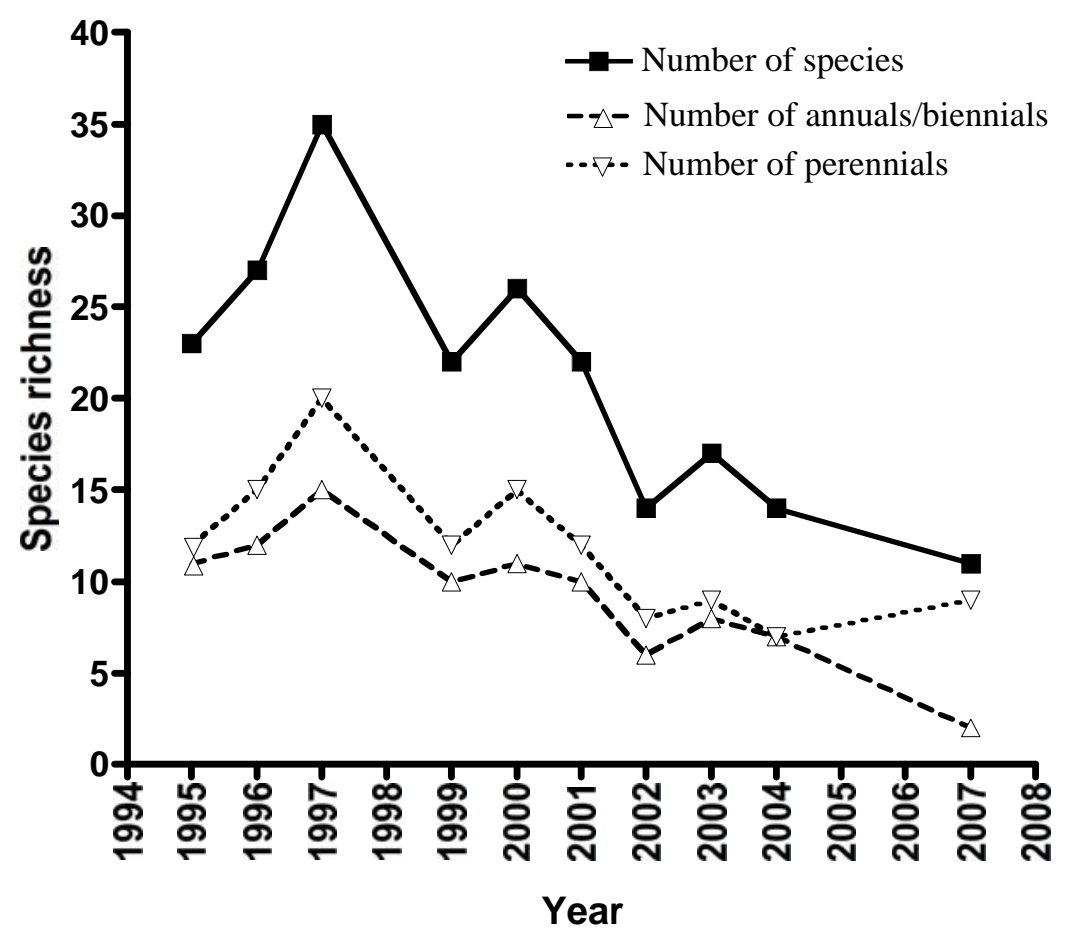

Figure 2.6. Temporal Variation in the Number of Annual/Biennials and Perennial Species Including Total Species on the Barrier. 


\subsection{Monitoring Infrastructure}

The barrier is instrumented for monitoring components of the water balance (i.e., precipitation, surface runoff, water storage, and percolation out of the root zone). Surface runoff is monitored with a $6.1 \mathrm{~m}$ wide by $15.2 \mathrm{~m}$ long erosion flume located in the northwest section of the barrier. The erosion flume is designed to capture and convey runoff to an automated water and sediment sampler. Water storage is monitored using vertical water content measurements taken by a neutron hydroprobe and by time domain reflectometry (TDR). Matric potential and soil temperature are measured by heat dissipation units (HDUs).

Percolation is monitored using a system of 12 concrete vaults located to the north and down-gradient from the asphalt layer to allow the movement of water by gravity (DOE-RL 1999). A series of curbs divide the asphalt surface into 12 water-collection zones, the boundaries of which align vertically with the 12 surface plots shown in Figure 2.7. Water reaching the curbed asphalt from the upper layers is piped to the drainage vaults. Under low flows into the vault, water flows through a datalogger-controlled tippingbucket rain gauge which monitors the flow rate. At higher flows, the system is designed for water to bypass the tipping buckets. Flow rate is then determined from the rate of change in hydrostatic pressure in the vault. Hydrostatic pressure is a function of water level in the vault and is automatically measured and recorded using pressure transducers. The combination of hourly tipping bucket and pressure transducer measurements provides good temporal resolution of the range of flow rates into the vaults.

Monitoring of deep percolation is facilitated by a $6.5 \mathrm{~m}$ by $6.5 \mathrm{~m}$ pan lysimeter installed under the northeast section (centered on plot 4E) of the asphalt layer (DOE-RL 1999). Any water siphoned from the lysimeter tube is routed to a tipping bucket and monitored by a datalogger. The lysimeter is monitored once every 24 hours. Horizontal access tubes are monitored by neutron probe to determine soil moisture content at the capillary break and beneath the asphalt pad. At the west side of the prototype surface barrier, two pairs of U-shaped, horizontal access tubes were installed at $1.95 \mathrm{~m}$ below the surface, near the capillary break (silt loam-sand filter interface) (Figure 2.7, AA1, AA2, AA3, AA4). A similar set of tubes (Figure 2.7, AA5, AA6, AA7, AA8) was installed at $1.95 \mathrm{~m}$ on the east side. Three additional sets of tubes were installed under the northeast section of the barrier below the asphalt layer. Tubes BA1 and BA2 were installed at a depth of $1 \mathrm{~m}$ below the asphalt, tubes BA3 and BA4 at $2 \mathrm{~m}$, and tubes BA5 and BA6 at $3 \mathrm{~m}$ below the asphalt layer. The northeast corner of the asphalt layer (under the north buffer zone) was left uncurbed to assess the amount of underflow at the edge of the asphalt.

\subsection{Existing Characterization Data}

The barrier was routinely monitored between November, 1994, and September, 1998, as part of a Comprehensive Environmental Response, Compensation, and Liability Act of 1980 (CERCLA) (42 USC 9601) treatability test of barrier performance for the 200-PW-5 (formerly the 200-BP-1) Operable Unit. Since FY 1998, monitoring has focused on a more limited set of key water balance, stability, and biotic parameters. However, no soil characterization data beyond bulk density and pea gravel content of the near surface soils have ever been collected. 


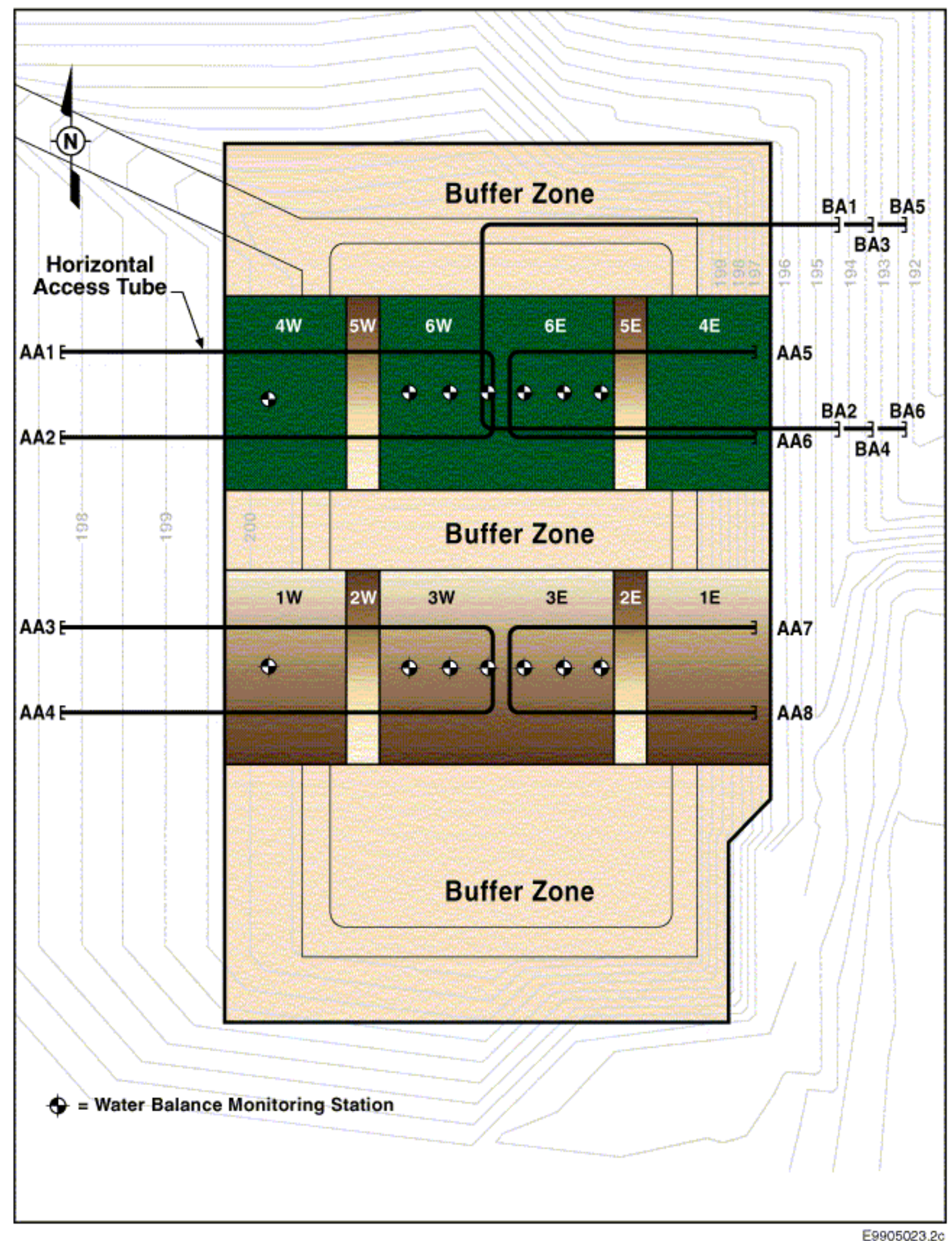

Figure 2.7. Plan View of the Barrier Showing the Layout of the 12 Surface Soil Plots (1W to $6 \mathrm{~W}$ and $1 \mathrm{E}$ to 6E) and Horizontal Neutron Access Tubes (AA-Above Asphalt; BA-Below Asphalt) 
During construction in 1994, the top $1 \mathrm{~m}$ of silt loam was amended with the addition of $15 \%$ by weight of pea gravel. The gravel was added to minimize wind and water erosion of the silt loam soil immediately after construction, when the surface was bare, and during periods of drought, wildfire, or any other period of increased eolian or aqueous stresses. Gravel samples collected in 1996 and 1997 from 24 locations on the silt-admix surface from depths of $0 \mathrm{~cm}-2 \mathrm{~cm}$ and $2 \mathrm{~cm}-10 \mathrm{~cm}$. The average bulk pea gravel concentration in September, 1996, was $13.8 \pm 2.3 \%$ compared to $14.1 \pm 1.5 \%$ in September 1995 . Differences in pea gravel content between the north and south halves of the barriers have also been reported (Ward et al. 1997). Measurements in September, 1996, showed a bulk pea gravel averaged 16.1 $\pm 2.8 \%$ in the north half and $11.6 \pm 1.9 \%$ in the south half. Earlier measurements in April, 1995, showed a mean of $14.3 \pm 1.6 \%$ in the north half and $13.9 \pm 1.4 \%$ in the south half. The difference between the two sections of the barrier was attributed to deflation due to the simulated 1,000 year return precipitation events on the north. The north half was expected to show larger gravel contents than the south half because the north was exposed to more water initially from irrigation which apparently removed or compacted surface silt to result in a higher gravel content in the near surface.

Hydraulic properties are limited to core samples measured in the laboratory prior to construction. There is no record of in situ hydraulic conductivity measurements made at the site. Specific surface area and cation exchange capacity have been measured for Warden silt loam and the pea-gravel (Ward et al. 2008). X-ray diffraction for mineralogy, elemental analyses, and gamma spectrometry has also been conducted on silt loam and pea-gravel fractions.

To date, runoff has been recorded at the barrier on only two occasions. One event occurred during the first simulated 1000 year storm event in March, 1995, designed to simulate the application of $68 \mathrm{~mm}$ of water over an $8 \mathrm{hr}$ period $(8.5 \mathrm{~mm} / \mathrm{hr})$. This was shortly after barrier construction at a time when vegetative cover was minimal. During that event, about $2 \mathrm{~mm}$ ( $2 \%$ of applied precipitation) of runoff was recorded. The second event occurred during the winter of 1997 when $36.3 \mathrm{~mm}$ of runoff was measured. This amount was attributed to a rapid snowmelt on frozen ground. No erosion was observed. In May, 2004, after severe thunderstorms, water collecting near the BY Farm eroded a berm and flowed down the north-western slope of the tank farm, eroding gravel armor in its path (Ward et al. 2004). The runoff water from the elevated BY-BX Tank Farm surface flowed down-gradient to the region between the tank farm and the prototype barrier damaging the west fence and eroding a channel over 40 inches deep at the base of the barrier side slope (Ward et al. 2004). Best management practices are being evaluated to mitigate the future occurrence of such events. 


\subsection{Simulated Fire and Associated Testing}

Simulated wildfire and associated testing will be conducted to quantify the effects of the fire. The fire will be treated as a prescribed fire and initiated and managed by the Hanford Fire Department. Prescribed burns are typically conducted under controlled settings to prevent escape, using fuel breaks and ignition patterns as control measures. The north section of the barrier will be divided into nine $12 \times 12 \mathrm{~m}$ plots separated for the simulated fire. Prior to the experimental burn, the plots will be characterized to establish initial conditions. Each plot will be randomly assigned one of two fuel load treatments for the test.

Monitoring of the fire and its effects will be based on the integration of point measurements of hydrologic and biotic variables with intermediate scale, non-invasive geophysical measurements techniques. These data will be collected in a fashion to provide ground truth data to remote sensing techniques in later phases of the project. Field monitoring will make use of existing surface and borehole geophysical techniques including TDR for moisture, neutron probe (moisture), neutron density gauge (surface moisture and density), ground penetrating radar (moisture, roots, root channels), and electrical resistivity (moisture, roots, root channels). A variety of laboratory techniques will be used to characterize changes in soil physical and chemical properties in response to the fire.

\subsection{Regulatory Requirements}

Work at the barrier is conducted under a Categorical Exclusion (CX) for accelerated remedial action of the operable unit, No. 8800-93-072 Rev. 1. The CX is listed in the DOE National Environmental Policy Act (NEPA) Implementing Procedures, 10 Code of Federal Regulations (CFR) 1021, Subpart D, which was published in the Friday, April 24, 1992, 57 Federal Register 15151:

B6.1 "Removal actions under CERCLA (including those taken as final response actions and those taken before remedial action) and removal type actions similar in scope under RCRA and other authorities (including those taken as partial closure actions and those taken before corrective action), including treatment (e.g., incineration), recovery, storage, or disposal of wastes at existing facilities currently handling the type of waste involved in the removal action. These actions will meet the CERCLA regulatory cost and time limits or satisfy either of the two regulatory exemptions from those cost and time limits (National Contingency Plan, 40 CFR part 300)...

(e) Capping or other containment of contaminated soils or sludges if the capping or containment would not affect future groundwater remediation and if needed to reduce migration of hazardous substances, pollutants, contaminants, or CERCLA excluded petroleum and natural gas products into soil, groundwater, surface water, or air..."

This CX is considered appropriate because the action would not have a significant effect on the human environment and meets the conditions for the CX. The CX, however, calls for a cultural resource review (CRR) and a biological survey. As part of site preparations, a biological survey was conducted to (1 determine the occurrence in the project area of plant and animal species protected under the Endangered Species Act (ESA), candidates for such protection, and species listed as threatened, endangered, candidate, sensitive, or monitor by the state of Washington, and species protected under the Migratory Bird Treaty Act), and (2 to evaluate and quantify the potential impacts of disturbance on priority habitats and protected plant and animal species identified in the survey. The survey found no 
plant or animal species protected under the ESA, candidates for such protection, or species listed by the Washington state government as threatened or endangered were observed in the vicinity of the proposed site. The complete biological review and its findings are presented in Appendix A.

A cultural resource review (NPCE\# 2008-200-024) was also undertaken as part of site preparations per 36 CFR Part 800, Subpart B, 800.3.a, the DOE-RL Cultural Resources Program. The cultural review determined that the simulated fire test is not the type of undertaking with potential to cause effects to historic properties and no further actions were required. Details of the cultural resource review are presented in Appendix B.

The fire test will be conducted under Prescribed Fire Permit No. 20080007 (Appendix A). This permit constitutes the authority to burn pending approval of this plan by the U.S. Department of Energy, Richland Operations Office. No one has the authority to burn without an approved plan or in a manner not in compliance with the approved plan. Actions taken in compliance with the approved Prescribed Fire Proposal will be fully supported.

\subsection{Site Preparation}

The surface of the barrier is currently demarcated on a $3 \times 3 \mathrm{~m}$ grid. This grid has been used as the basis documenting spatial changes in parameters of interest for the duration of monitoring and will be used for the fire effects test. Figure 3.1 shows a schematic of the barrier surface with the existing grid. There are 6 monitoring stations on the north side on the barrier (S1 through S6) and one on the north side of the gravel side slope (S7, not shown). The surface will be first divided into nine $12 \times 12 \mathrm{~m}$ plots to be used in the simulated fire test during which time any missing grid markers will be replaced. A surface topographic survey will also be completed at this time.

Although one of the original objectives of the testing program at the prototype barrier was to investigate monitoring technologies and establish a cost basis for long-term monitoring, not much consideration was given to fire protection during the installation of instruments. Thus, a necessary task will be to prepare these installations for the proposed tests, which will involve providing some means of fire protection. Instruments from the monitoring stations are connected to data loggers housed in two large polyethylene boxes, as shown in Figure 3.2. A number of cables also run over the surface in PVC conduit (Figure 3.2). None of the instrument boxes were mounted flush with the surface so as to minimize the potential for water or snowmelt running into the boxes. Consequently, most of the cables and conduits used for the cables are exposed near the entry point to the boxes. None of the conduits on the side slope are buried. Preparation for the simulated fire will therefore require that conduits and cables be buried or otherwise protected. This may require that the instrument boxes be buried such that they are flush with the surface or that they be protected with thermal blankets. All cables will be run through conduit and buried in a shallow hand-dug trench running along the stone pathway that is used to access the barrier's surface. Thermal blankets will be used to cover the instrument boxes, solar panels and other infrastructure for the duration of fire test. 


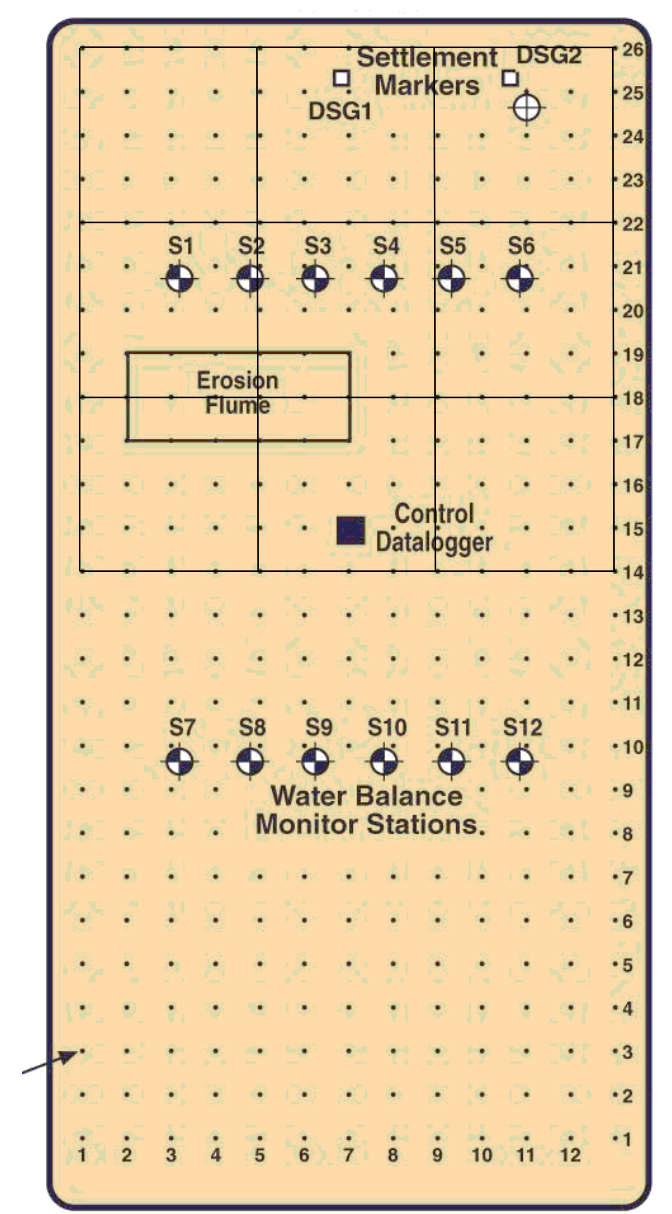

Figure 3.1. Schematic Plan View of the Barrier's Surface Showing Monitoring Stations, the Runoff Plot, the $3 \times 3 \mathrm{M}$ Grid, and the Nine $12 \times 12 \mathrm{M}$ Plots to Be Used for Comparing Fuel Loads on Fire Intensity.
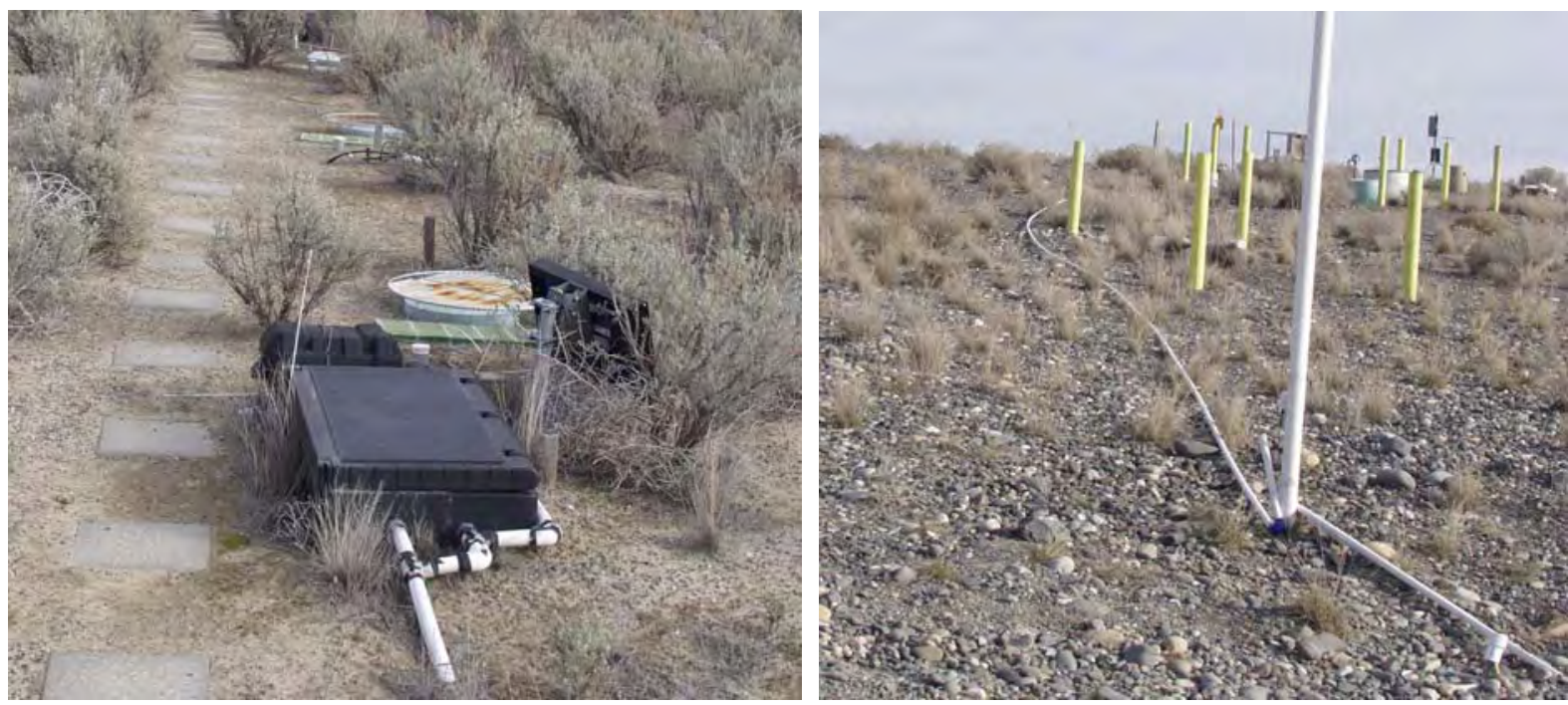

Figure 3.2. Photographs of the Barrier Surface and Gravel Side Slope Showing Examples of Monitoring Infrastructure on the Surface That Will Need Protection From the Simulated Fire. 
Six minirhizotrons, constructed of clear acrylic tube, were installed on the barrier to measure root distributions as part of the CERCLA treatability test (DOE 1998). These tubes will be used for root length density measurements but have not been used in over 10 years. The tubes will first be assessed to determine their condition, cleaned, and replaced, if necessary.

For the simulated fire, it will be necessary to import fuel onto the barrier to increase the fuel load. This material will have to be weighed and the moisture content determined. An electronic balance will be temporarily installed to weigh the imported fuel, which is expected to consist of dead sagebrush and tumbleweed. To minimize the migration of tumbleweed and other fuel to the east into the BY tank farm, a $4 \mathrm{ft}$ high safety fence (orange plastic netting) will be installed along the east side of the barrier. Some of the planned measurements, for example, hydraulic conductivity using the tension infiltrometer, and nondestructive surface moisture and density measurements require that the soil undergo some preparation to remove rough surfaces prior to measurement. Small voids, cracks, or holes will be filled with silt loam from the storage pile to accomplish this.

Progress of the fire will be documented using a video camera configured to view the entire burn area. Prior to the burn, a tower for installation of the video camera will be installed and the camera system mounted and tested. During the fire, flame height will be measured by recording elevation of the flame on flame-height rods mounted within each plot. Flame height rods will be constructed of galvanized pipe and painted in alternating black and white $10 \mathrm{~cm}$ sections to permit easy determination of flame height. Each unit will be self supporting to allow installation without the need to core into the barrier surface.

Fire intensity will be determined from temperature measurements made in each of the 12 plots using thermocouples. These thermocouples will be installed at different elevations above the surface by mounting on metal towers. These self-supporting towers will also be constructed of galvanized pipe with branches at appropriate heights for installation of the thermocouples. A photograph of several prototype towers is shown in Figure 3.3. A similar design will be used to monitor flame height.

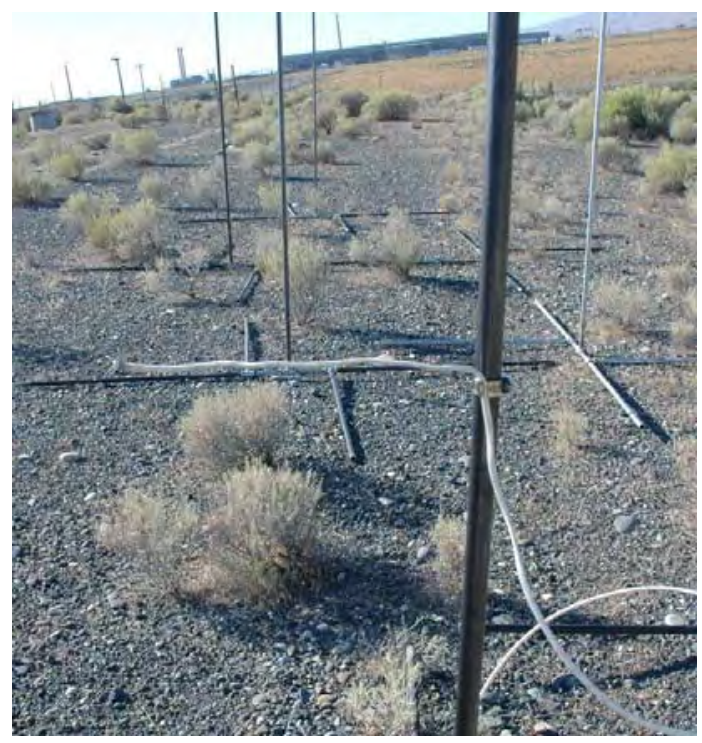

Figure 3.3. Photograph of Thermocouple Towers to Be Used for Monitoring Temperature at Different Elevations During the Simulated Fire. A tower with one thermocouple is shown in the foreground. 


\subsection{Pre- and Post-Fire Biological Monitoring}

Wildfire can strongly affect plant community composition and structure. Thus, both plant and small mammal information will be collected pre- and post burn. Plant information to be collected includes a species list for the formerly irrigated (north) section and formerly non-irrigated (south) section of the barrier and for the north and west side-slopes. Shrub height, greatest canopy diameter, and the diameter at the center of the plant perpendicular to the greatest diameter will be measured on a minimum of 25 shrubs each from sections of the barrier. General assessments of shrub survival, re-sprouting, and recruitment will be made. A similar type of assessment will be made on an undisturbed site located on representative silt-loam surface (e.g., McGee ranch) to serve as a control.

\subsubsection{Fuel Load Characterization}

In a recent study, De Macro et al. (2005) compared two different fuel loads, $4 \mathrm{~kg} / \mathrm{m}^{2}$ and $2 \mathrm{~kg} / \mathrm{m}^{2}$. The $4 \mathrm{~kg} / \mathrm{m}^{2}$ load resulted in complete combustion of the vegetation whereas $2 \mathrm{~kg} / \mathrm{m}^{2}$ resulted in only partial combustion. Nevertheless, both fires induced long-lasting decreases in soil organic matter and in the total and available fractions of nutrients and trace elements. Thus, before the fire is initiated a number of site properties will be characterized to determine fuel load and need for additional fuel. As shown in Figure 2.3, there are significant differences in plant density and fuel load on the surface. Fuel characteristics will be measured with a geostatistical sampling scheme (Robichaud, 1996, Robichaud and Miller, 2000).

In addition to fuel characteristics, the biomass of the cover will be estimated. This will be done by measuring the canopy characteristics of height, greatest width, and greatest diameter at right angles to the greatest width on Artemisia tridentata (sagebrush). These measurements will be made on ten individual plants off the barrier surface that cover the range of plant sizes on the barrier surface. These ten plants will then be harvested, weighed, dried, and weighed again. This will allow us to compute fuel moisture content. These canopy characters will then be measured on at least 30 individual A. tridentata plants on the barrier surface to estimate shrub fuel density.

Biomass of other fuel components on the surface will also be estimated. Some areas of the barrier surface are quite sparse in vegetative cover and will require an increase in biomass in order to reach representative fire intensities and severities (e.g., Figure 3.4a). Other fuel components are primarily Salsola kali (tumbleweed). Tumbleweed is already lodged among the A. tridentata plants on the surface (Figure 3.2, Figure 3.4) and more may be brought in to ensure a complete burn of the surface. Ample amounts are typically available near to the barrier. Figure 2.3 shows a large accumulation of dry tumble weed at the southeast corner of the barrier. A similar accumulation is shown at the northeastern base of the eastern riprap slope (Figure 3.4b). 


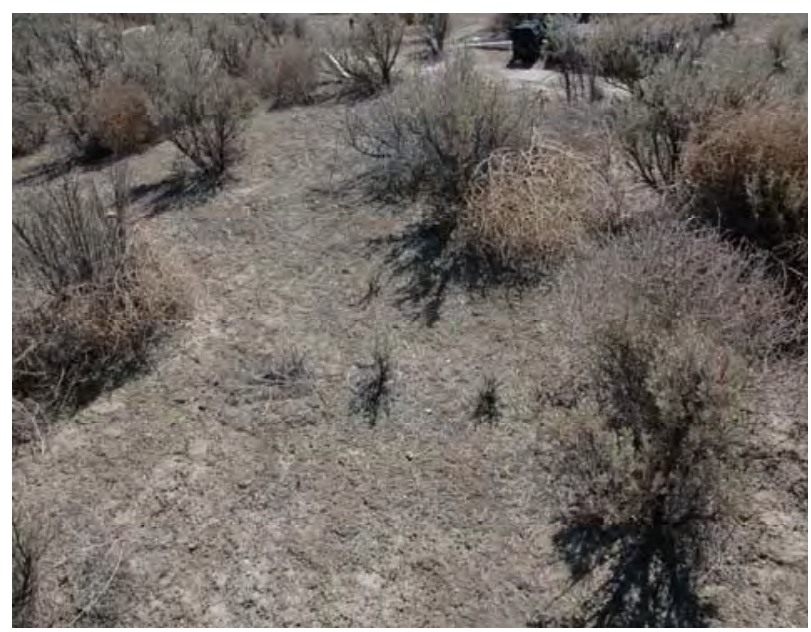

(a)

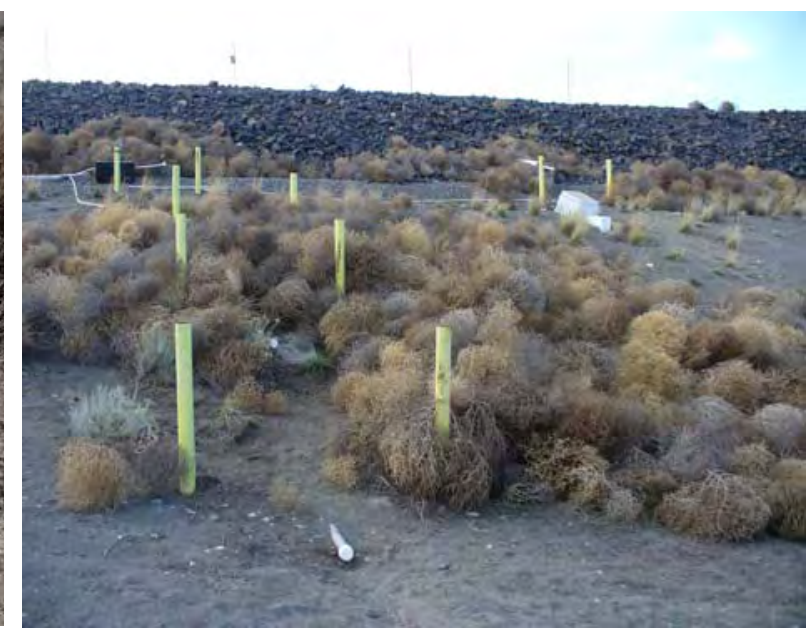

(b)

Figure 3.4. Photographs of the Barrier's Surface (a) Sparse Vegetation on the Surface Suggesting Need for Increased Fuel Load to Ensure Realistic Fire Characteristics, Some Salsola Kali (Tumbleweed) is Already Logged Among Sagebrush Plants, and (b) The Rip Rap Side Slope of the Barrier Showing an Accumulation of Tumbleweed. Dead sagebrush and tumbleweed will be imported to the barrier surface to increase the fuel load.

Given that ground cover will be estimated before the fire in each of the sample quadrants on the surface, relations between tumbleweed biomass cover will be developed. This will be done by estimating tumbleweed cover in a quadrant and then collecting the biomass and weighing it. A sample of collected biomass will then be weighed separately and oven dried so biomass can be expressed as oven dried biomass. This estimation will be done on 5 to 10 plots covering the range of tumbleweed cover on the surface. Additional tumbleweed biomass will be brought onto the surface to be loaded into plots that are lacking in sufficient fuel to carry the fire. However, the amount of $S$. kali needs to be estimated and the precedent for this is currently lacking. For the actual test, each $12 \times 12 \mathrm{~m}$ plot will be randomly assigned one of two different fuel loads, $2 \mathrm{~kg} / \mathrm{m}^{2}$ or $4 \mathrm{~kg} / \mathrm{m}^{2}$.

\subsubsection{Plant Root Distributions}

The traditional approach to evaluate root biomass is to harvest roots using soil cores and trenches, but this is destructive, labor intensive, and interrogates only limited soil volumes. Root or minirhizotron cameras are nondestructive and relatively fast. Transparent plastic tubes are typically buried to a depth of $1 \mathrm{~m}$ (at an angle of $45^{\circ}$ ) in the soil to allow a digital camera to be periodically lowered for photographing roots through the wall of the tube. These photographs can be used to monitor the growth of roots over time. By comparing the lengths of roots in digital images taken at different times, a quantitative estimate of a plant's allocation to root biomass over the corresponding time period can be determined.

A Circon Agricultural Camera minirhizotron system will be used to map root length densities at the barrier. Six minirhizotrons, constructed of clear acrylic tubes (51 mm id.) were installed in the north and south portions of the surface at an angle of $45^{\circ}$ to the surface at the start of the treatability test (DOE 1998). Root observations will be made through the minirhizotrons on the north side of the barrier. Videos of each root tube will be examined to compute root length density. This will be done by counting each root that intersects with the tube surface and each intersecting branching root from a root already in contact with the tube. Roots will be counted separately for live and dead roots. Post-fire monitoring will 
continue to track the ratio of live to dead roots and the time to complete root death and the formation of preferential flow paths, if any. Live roots are white to brown and turgid with some roots having root hairs. Dead roots are dark in color and contracted within root channels in the soil. However, differentiating live from dead roots is subjective. Counts will be taken in an area the width of the viewing area $(1.55 \mathrm{~cm})$ and $10 \mathrm{~cm}$ long. The count data are then divided by the observation area to yield a root length density value (Upchurch and Ritchie 1983, 1984).

In addition to root camera measurements, geophysical methods will be used to investigate the shape and behavior of the roots in the subsoil. Two techniques that have been finding increased application for indirect estimates of root volume are ground penetrating radar (GPR), and electrical resistivity (ER) (Butnor et al. 2001, Hruska et al. 1999, Wielopolski et al. 2000, Stokes et al. 2002). GPR is a portable, non-invasive technique and has perhaps the highest resolution of any subsurface imaging method. GPR is capable of detecting the distribution of the roots in the subsoil with fairly high resolution compared to other noninvasive methods. The ER technique measures the subsurface distribution of the volumetric resistivity from a large number of current and potential measurements using electrodes installed at the surface. Three dimensional ER can be useful in correlating the recovered resistivity distribution with root volumes. By accurately calculating the soil resistivity it is possible to detect soil water, fine-textured soil layers, and soil voids. It is also possible to reconstruct sections of the ground that can be used to choose and calibrate the parameters for GPR surveys.

High-resolution 3-D GPR, broad-band electrical conductivity, and electrical resistivity surveys will be conducted on perpendicular lines at a high enough density to allow detection of roots and other features. The frequency of the GPR will be chosen such that depth of penetration is between $1.5 \mathrm{~m}$ and $2 \mathrm{~m}$. Conductivity and resistivity surveys will be performed with a fine enough resolution to permit construction of a 3-D model of the subsurface and to allow the mapping of the complex root systems.

\subsubsection{Canopy Characteristics}

Vegetation surveys will be conducted to characterize density, ground cover, and leaf area index (LAI) in three communities in silt loam soils to cover the range of common density and cover (low, medium, and high) before the fire. This will also be done to determine if a thinning treatment is needed on the unburned portion of the barrier surface. Three study areas will be chosen in McGee Ranch soils or very similar soils. The three communities chosen will then be sampled to estimate plant density, cover distribution, and leaf area index. This sampling will be performed on the barrier with measurements at McGee ranch to serve as controls for this type of ecosystem.

On the barrier cover surface, sagebrush density will be determined by counting the number of individual rooted shrubs in each of the nine $12 \times 12$ plots on the north half of the barrier and a similar number on the south. In each plot the number of shrubs in at least three age classes will be counted. These age classes are 14 years old, 3 years old, and new seedlings. The density of gray rabbitbrush will also be determined on the surface. Measurements will be made at the McGee Ranch to serve as a control. There, an area of similar size to the barrier surface will be located and a $12 \times 12 \mathrm{~m}$ grid also established for sampling to determine shrub density by age class. Ground cover will be determined in the same plots as those used for density determination at the three field sites. These measurements will be made by visual inspection for each species, litter, and bare soil. Soil cryptogam type will be determined and ground cover will also be estimated. In addition, soil cryptogams will be monitored for species and cover 
before and after the fire. Ground cover will also be determined on the north and west side slopes of the barrier. LAI will be estimated, using a LiCor Plant Canopy Analyzer, on each plot at the three sites to determine density.

When considering the impact of wildfire, the ability of a plant species to re-sprout after fire and the ability to recruit from persistent seed banks are two of the desirable attributes of an ideal species for revegetation. In terms of understanding wildfire effects on post-fire regeneration, relationships between measures of fire intensity, such as maximum temperature or heating duration ,on the survival of seed banks will be evaluated. The seed bank on the barrier will be assessed in each of the $12 \times 12 \mathrm{~m}$ plots by collecting surface soils and germinating seed in the greenhouse. Plant water potential will be assessed before and after the fire (as possible on re-sprouts) and in the unburned half before and after the fire.

\subsubsection{Small Mammal Habitat}

The important ecological role of small mammals, along with their ubiquitous nature, makes them important tools in clarifying and comparing the effects of fire on habitat change (Larsen et al. 2007).

In order to understand the pattern of small mammal communities within engineered ecosystems altered by fire, the composition, demography, and variation of small mammals and insects on the north half of the barrier will be examined. Measurements will be made pre- and post burn with the south, unburned half acting as the control. The barrier surface will be examined for evidence of use and intrusion (burrowing) by insects and small mammals. Indications of animal use include direct observation and presence of droppings, tracks, nests, burrows, holes, or resting spots. Small mammal traps will be used to positively identify vertebrates on the surface before and after the fire to the extent possible.

\subsection{Simulated Wildfire}

The fire will be initiated and managed by the Hanford Fire Department in accordance with the HFD 2008 Annual Prescribed Fire Proposal (Appendix A). If available, spot weather forecast should be obtained at least one-hour before initiating the burn. The Hanford Meteorological Service's weather stations at http://etd.pnl.gov:2080/HMS/ will be used to monitor conditions during the burn. Site-specific information will also be used. Burning prescriptions for air temperatures of $80^{\circ} \mathrm{F}$ to $90^{\circ} \mathrm{F}$, relative humidity between $15 \%$ and $60 \%$, and wind speeds between $0 \mathrm{~m} / \mathrm{s}$ and $3 \mathrm{~m} / \mathrm{s}$ at the lower humidity and up to $8 \mathrm{~m} / \mathrm{s}(18 \mathrm{mph})$ at the higher humidity. Spot weather forecast information will be solicited from the National Weather Service in Pendleton, Oregon. HFD units at the test site will have foam lines used as breaks, minimal impact suppression tactics will be enforced in these areas. The simulated fire test will be conducted on the north half of the barrier and will include both the silt loam cover and the gravel side slope (Figure 3.5). A 3-m wide line of fire retardant foam will be used to protect the south portion of the barrier during the burn.

\subsubsection{Silt-Loam Cover}

Each $12 \times 12 \mathrm{~m}$ plot will be ignited around the perimeter with a drip torch and the flames allowed to carry to the center. Ignition will be performed at a rate to meet prescription objectives. Any plots with 


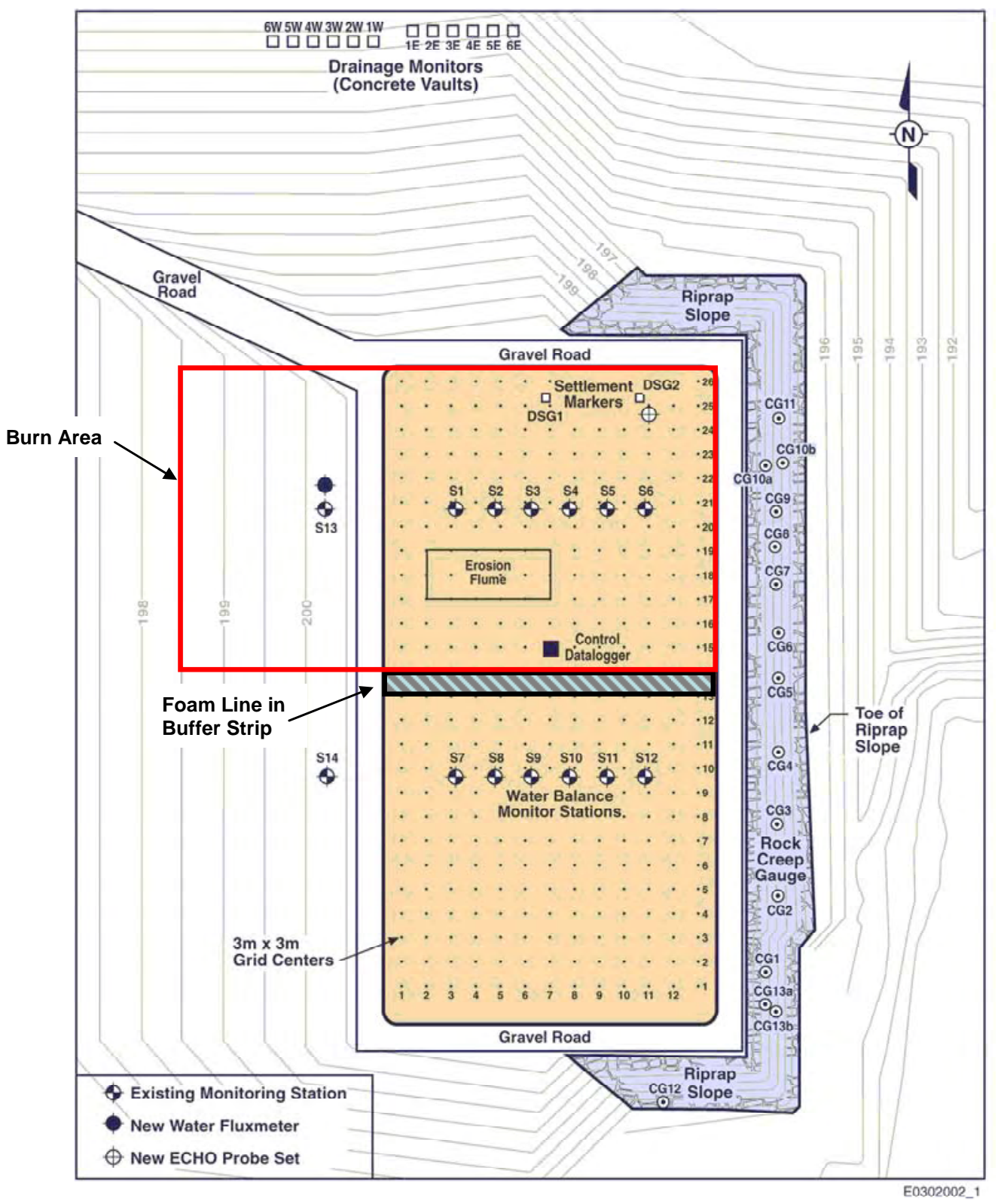

Figure 3.5. Schematic Plan View of the Barrier's Surface Showing Proposed Burn Area on the Gravel Side Slope and Silt-loam Surface. A 3 m wide line of fire retardant foam will be used to protect the south portion of the barrier during the burn. 
incomplete combustion after the simulated fire will be burned off using a drip torch. All areas will be monitored until threat of spotting has ceased. The fire will be documented from ignition through completion using a variety of methods. Progress of the fire will be documented using a tower-mounted video camera configured to view the entire burn area. After the burn, the surface will be examined and recorded to identify any mosaic patterns that are indicative of variable fire severity. Additional still photographs will be recorded using digital cameras. Digital time-lapse photography will also be used to monitor ecological succession after the burn. Flame height will be determined using decimeter scale flame height rods (black and white metal rods) installed outside at the edge of plots. Flame height will be measured by peering through the flames to the meter stick and recording elevation of the flame.

Photographs will also be taken as the fire passes each rod. Flame speed will be determined by measuring the time to travel from the ignition line to the thermocouples, which will be located $3 \mathrm{~m}$ from the edge of the plot.

Fire intensity will be determined from temperature measurements made at the center of each of the nine $12 \times 12$ plots (Figure 3.1). Measurements will be made using fast-response J-type thermocouples (e.g., diachromel-alumel) with fire-resistant insulation mounted on a metal tower. Thermocouples wires will be wrapped in aluminum foil to provide additional protection if necessary. Temperatures will be measured at, (1 the surface, $(25 \mathrm{~cm}$ and $10 \mathrm{~cm}$ below the surface, and ( 3 above the surface at elevations of $15 \mathrm{~cm}, 50 \mathrm{~cm}, 100 \mathrm{~cm}$, and $200 \mathrm{~cm}$. Above-ground thermocouples will be mounted on a metal tower located at the middle of each plot. Temperatures will be scanned continuously and the maximum temperature recorded every 15 seconds, before, during, and after the fire until the surface cools back to ambient conditions. Each thermocouple will be connected to a Hobo datalogger, which will be housed in a fire-poof box at the base of each tower. In addition to the thermocouples, the existing array of HDUs will be reprogrammed to measure soil temperature as the fire proceeds. Heat dissipation units are currently installed at depths of $175.05 \mathrm{~cm}, 125.05 \mathrm{~cm}, 80.05 \mathrm{~cm}, 45.05 \mathrm{~cm}, 23.05 \mathrm{~cm}$, and $7.5 \mathrm{~cm}$ below the surface.

Fire intensity is a good indicator of above-ground fire effects such as scorching height and other biological impacts (Albini 1976, Borchert and Odion 1995). Three measures of fire intensity will be used to characterize fire behavior, 1) the maximum temperature at three vertical profile levels, 2) total duration of elevated temperature at these three levels, and 3) fire line intensity. Elevated temperature duration will be determined by summing the areas under the curves above pre-ignition ambient temperature at each thermocouple. Fire line intensity represents the active front of a fire or the rate of energy release per unit time per unit length of the fire front due to flaming combustion. Fire line intensity will be calculated according to Byram (1959) as

$$
I=H W R
$$

where $H$ is the heat of combustion ( $\mathrm{kJ} / \mathrm{kg}$ of fuel), $W$ is the consumed fuel, and $R$ is the rate of fire spread $(\mathrm{m} / \mathrm{s})$, giving a fire line intensity, $I$, in $\mathrm{k} / \mathrm{Wm}$. The average value for the total heat of combustion for a wide range of plant fuels is $18,700 \mathrm{~kJ} / \mathrm{kg}$ (Johnson, 1992). Other measures of fire intensity, such as the maximum temperature and duration of heating, will also be measured because they sometimes have greater effects on ecological components such as seed banks (Beadle 1940, Armour et al. 1984, Bradstock and Auld 1995, Brooks 2002). Least-squares regression will be used to evaluate relationships between different measures of intensity. 


\subsubsection{Gravel Side Slope}

In addition to testing the performance of a capillary barrier design with an ET barrier top-soil component, the Hanford Prototype Barrier was constructed using two different side-slope designs: (1) a relatively flat apron (10:1) of pit-run sand and gravel on the west side and (2) a relatively steep (2:1) embankment of fractured basalt riprap on the east side. These side-slope designs were constructed to evaluate water infiltration and material stability. Both side-slope designs have remained stable. The riprap side-slope remains barren for the most-part while there has been a slow, but persistent increase in vegetation on the pit-run sand and gravel side-slope. The vegetation on the pit-run sand and gravel sideslope is sparse, and comprised primarily of rabbit-brush and some perennial grasses.

A portion of the west gravel side-slope of the barrier will also be burned. Due to the sparse vegetation and lack of fuel, each plant will be individually burned using a drip torch after the surface portion of the barrier has been burned and fire crews are in a "hot-spot" monitoring mode. The primary objective of burning the west side-slope is to evaluate natural revegetation on a portion of the barrier that has a different soil composition than the main surface of the barrier (i.e., pit-run sand and gravel versus fine-grained silt loam). Moisture monitoring can be conducted using three horizontal neutron probe access tubes that are within the confines of the pit-run sand and gravel side-slope area. In addition, runoff will be evaluated.

Approximately 40 meters to the northwest of the pit-run sand and gravel side-slope is a drum storage area for investigation derived waste (IDW) collected during 200-BP-5 Groundwater Operable Unit well drilling activities. The drill cuttings may contain low levels of Technetium-99 as a result of a regional groundwater plume underlying the area; however, laboratory results for volatile and semi-volatile organics are below detection limits. The " $F$ " codes listed on the drums are based on information provided in WAC 173-303-9904, "Dangerous Waste Source List,” and are a result of a past decision regarding the application of listed waste codes to secondary solid wastes related to well construction, maintenance, and sampling. This decision is documented in an August 1, 2000 Environmental Restoration Contractor (Bechtel Hanford, Inc.) interoffice memorandum (\#081034, J. Borghese to Distribution). However, the IDW drums and their contents should not be a concern from the barrier burn perspective as laboratory analyses for volatile and semi-volatile organics were below detection limits. Furthermore, the Hanford Fire Department has the option to put down a "foam line" to prevent the fire from encroaching upon the IDW drums, if needed.

\subsection{Fire Effects on Hydrophysical Properties}

Soil properties will be characterized pre- and post burn to quantify any changes in hydrophysical properties resulting from the fire. A suite of standard tests will be conducted to characterize these properties. Soil texture will be determined using a combination of wet sieving and hydrometer. In addition, a number of specific tests, described below, will be conducted.

\subsubsection{Surface Layer Composition and Inflation/Deflation}

During construction, the top $1 \mathrm{~m}$ fine-soil surface layer of the barrier was amended with the addition of 15 wt.\% pea gravel as a means of protecting soil erosion (Ligotke 1994, Ward et al. 1997, DOE 1998). Long-term changes in the surface layer composition may be expected as the surface ages under both 
deflationary and inflationary influences of soil loss or gain. Changes in surface layer composition may also be expected following a fire that removes the vegetation and surface litter that protects the soil surface from raindrop impact and erosion by water and wind.

Measurements of surface composition will be conducted on soil samples collected from the barrier's surface. Four core samples will be collected from the four $3 \times 3 \mathrm{~m}$ quadrants of each plot. Samples will be collected by coring the soil column in two increments, one from $0 \mathrm{~cm}-2 \mathrm{~cm}$ to collect a "surface" sample and the other from $2 \mathrm{~cm}-10 \mathrm{~cm}$ to collect a "bulk" sample. Each sample will be analyzed to determine the particle size distribution. Soil samples will separated into four grain-size fractions, namely, gravel, sand, silt, and clay and sub classes (very coarse, coarse, medium, fine, and very fine) based on the logarithmic Udden-Wentworth grade scale (Wentworth 1922). In this scale, the boundaries between successive size classes differ by a factor of two. Dry sieving will be used to separate gravel and other particles greater than $2 \mathrm{~mm}$ in diameter. The wet sieving/hydrometer method will be used to determine particle size distributions of the $<2 \mathrm{~mm}$ fraction and will be performed according to the methods of ASTM (2007) and Gee and Bauder (1986).

Sample-size fractions by weight will be converted into percent-by-weight passing each sieve and plotted as a curve on a semi-logarithmic scale to give the grain size distribution. The percentage of each size fraction will be used to determine texture according to the USDA classification and the Unified Soil Classification System specified by ASTM D2487-00 (ASTM 2000). Grain-size statistics will be calculated from the grain-size distributions using the methods described by Ward et al. (2006). The particle size moments of the distributions and the related coefficients, e.g., coefficient of uniformity, $\mathrm{C}_{\mathrm{u}}$, and coefficient of curvature, $C_{c}, d$-values of the gradation curve $\left(d_{16}, d_{50}, d_{85}\right)$ will be calculated from the grain-size distributions using the methods described by Folk (1980).

Samples will be collected prior to the burn to establish the initial condition and to quantify the amount of inflation or deflation that has occurred over the last decade of the barrier's life. Sampling and analysis will continue after the simulated fire to document deflationary and/or inflationary periods and the conditions under which they occur. During deflationary periods, the visible exposed concentration of pea gravel at and near the surface is expected to increase and form armor as soil particles are removed by wind. During inflationary periods, a layer of soil that is largely free of pea gravel is expected to form on the surface. These data should reveal the ability of the surface to resist erosive stresses after fire and provide insight into changes in surface composition relative to the bulk composition of the top $1 \mathrm{~m}$ of admix.

\subsubsection{Fire Effects on Soil Wettability}

Wettability of soils has a considerable impact on water movement, particularly on infiltration and, therefore, surface runoff. An important phenomenon affecting infiltration or water movement in soils is the hydrophobization of originally wettable mineral particles by coatings of organic substances of different origin (Wallis and Horne 1992). Fires are known to lead to hydrophobization, inducing water repellency, and changing the mechanical properties of surface soils to impact soil erosion and hydrological response to precipitation events. Plant residual wax and lignin components are often residuals from combustion and the extent of hydrophobization is dependent on several factors including soil texture and soil moisture content during the fire. The severity of water repellency measured on dried soil samples, the so-called "potential” water repellency, can be used as a parameter for comparing soils 
with respect to their sensitivity to water repellency. To quantify the importance of this phenomenon at the barrier, measures of water repellency will be made on soil samples prior to the burn and at different times after the burn.

Measurements of water repellency will be made using the water drop penetration time (WDPT) test (Dekker and Ritsema 1994, Dekker 1998). The WDPT test is conducted by placing a water drop on the soil surface and recording the time required for the water to infiltrate. Soil cores of $1.9 \mathrm{~cm}(3 / 4 \mathrm{inch})$ diameter will be taken to a depth of $20 \mathrm{~cm}$. The water droplet penetration test will be conducted on cores from $0 \mathrm{~cm}$ to $20 \mathrm{~cm}$ in $5 \mathrm{~cm}$ increments. The soil $(<2 \mathrm{~mm})$ will be placed on a Petri dish and the surface smoothed. Three drops of distilled, de-ionized water, each containing $36 \mu \mathrm{L}$ will then be randomly placed on the air-dry sample and the penetration time measured. The median value of the infiltration time of the three drops is considered as the drop penetration time at the analyzed depth and the soil is considered hydrophobic if the WDPT is greater than 5 seconds (DeBano, 1981). The maximum time allowed for water droplet penetration is 600 seconds. Any water droplet remaining after 600 seconds will be recorded as 600 seconds. Measurements will be made on the whole (unsieved) soil and on narrowly sieved particle-size fractions (e.g., <62 $\mu \mathrm{m}, 62 \mu \mathrm{m}$ - $125 \mu \mathrm{m}, 125 \mu \mathrm{m}$ - $250 \mu \mathrm{m}, 250 \mu \mathrm{m}$ - 500, and $500 \mu \mathrm{m}$ $1000 \mu \mathrm{m}$ ) to identify the size increment that is most susceptible to hydrophobization. Depending on the fire intensity and severity, a decrease in wettability can be expected.

\subsubsection{Fire Effects on Hydraulic Conductivity}

Saturated hydraulic conductivity will be measured at different locations on each plot using a Guelph permeameter (Reynolds et al. 1984). With the Guelph permeameter method, water flux into the soil is measured until a saturated bulb is formed around the borehole and the outflow of water from the storage cylinder reaches a constant value. The saturated hydraulic conductivity is then calculated using the constant head permeameter method, based on the Reynolds and Elrick (1985) solution of Richards' equation for steady flow out of a well.

Water movement in the surface soils of engineered barriers frequently occurs as unsaturated flow, and is primarily controlled by the unsaturated hydraulic conductivity of the soil. Field measurements of unsaturated hydraulic conductivity $(\mathrm{K}(\psi))$ is therefore necessary for characterizing many aspects of unsaturated water flow including infiltration and runoff. Unsaturated hydraulic conductivity will be measured at different locations on each plot using a Guelph tension infiltrometer (Reynolds 1993) The tension infiltrometer is also capable of giving estimates of several parameters useful for characterizing soil structure.

Since the Guelph permeameter/tensiometer methods yield only point measurements, four measurements will be made inside each $12 \times 12 \mathrm{~m}$ plot (one in each $3 \times 3 \mathrm{~m}$ quadrant) to provide representative values of the hydraulic conductivity before and after the burn. Relationship to fire intensity, severity, and fuel load will be established using geostatistical methods.

\subsubsection{Fire Effects on Infiltration Rates and Runoff}

Robichaud (2000) suggested that under fire-induced water repellent conditions, runoff rates should quickly peak and then begin declining as the hydrophobic substances of the soil are broken down, thus increasing infiltration over time. He also showed that before a severe burn occurs, little water repellency 
should exist within the soil. Thus, rainfall simulation tests will be conducted to characterize infiltration rates and surface runoff. There is a paucity of runoff data for the Hanford site collected under well defined or controlled conditions and this complicates model calibration for predicting barrier performance.

Simulated rainfall tests will be conducted on $1 \mathrm{~m}^{2}$ plots with an overhead oscillating nozzle rainfall simulator. The simulator is capable of applying variable rates but will be used to apply water at a mean rate of $8.5 \mathrm{~mm} / \mathrm{hr}$, the equivalent rate for the 1000 -yr return storm in which $68 \mathrm{~mm}$ of water was applied over 8 hrs. Each plot will be bordered by a $15 \mathrm{~cm}$ wide metal sheet inserted vertically $5 \mathrm{~cm}$ into the soil. Each plot will be exposed to three 30 minute rainfall campaigns, RF1, RF2, and RF3. The first simulated rainfall event, RF1, will be applied under existing soil moisture conditions immediately after the fire. After RF1, the plots will be covered overnight with plastic sheeting to protect from natural rainfall events and the RF2 test will be conducted the next day. Test RF3 will be conducted within 30 minutes of the completion of test RF2. This protocol is intended to provide three distinct antecedent moisture conditions, dry (RF1), wet (RF2) and very wet (RF3). A covered trough at the lower end of each plot will carry runoff (water and sediment) through an outlet tube to an automated ISCO water/sediment sampler where timed volume samples will be collected in $500 \mathrm{ml}$ bottles.

The resulting data will be used to develop runoff hydrographs, total runoff volumes and sediment yields and to quantify the effects of hydrophobicity. Hydrographs will show the temporal variation in runoff rate $(\mathrm{mm} / \mathrm{h})$ for three different rainfall rates and antecedent moisture contents. Runoff amounts will be calculated by the integration of the hydrograph. The resulting hydrographs will then be used to calculate hydraulic conductivity according to the methods of Luce and Cundy (1994) that can be used to determine parameter values for kinematic wave-Philip's infiltration overland flow equation from runoff hydrographs. This approach minimizes the error between the observed and predicted hydrographs by adjusting the values for the sorptivity, hydraulic conductivity, time to ponding under constant rainfall rate and duration, plot slope and size, and moisture contents. Required inputs are saturated hydraulic conductivity, which will come from the Guelph permeameter measurements.

\subsubsection{Fire Effects on Soil Water Retention}

Changes in wettability can also be expected to impact the water retention behavior of soils that could potentially impact the water storage capacity and ultimately the components of the water balance. To evaluate these effects, water retention properties will be measured on 6 samples collected in the $0 \mathrm{~cm}$ $5 \mathrm{~cm}$ depth and 6 from the $5 \mathrm{~cm}-10 \mathrm{~cm}$ depth. Water-retention measurements will be made using a controlled volume technique (Winfield and Nimmo 2005). This method is relatively fast for large, undisturbed samples where repacking is undesirable in order to preserve natural structure. Pressure equilibration is faster than with other techniques, since approximately half of the sample de-saturates during a given step. The method is limited to pressures in the range of $0 \mathrm{~cm}$ to $-1000 \mathrm{~cm}$ water. The controlled volume method allows determination of points on the water retention curve by extracting or adding water to a sample in fixed-volume increments and allowing the matrix potential, $\psi$, to equilibrate. During each time step, a known volume of water is extracted (for drying curve) or added (for wetting curve) to bring the sample to a known average water content, $\theta$, and the volumetric water contents and matrix pressure determined. We will use a vapor equilibrium method to obtain the water retention down to around $2.5 \times 10^{6} \mathrm{~cm}$ of suction according to ASTM D6836-02 (ASTM 2000). Porosity measurements will be made on the samples used for water retention by measuring the water content at saturation with 
time domain electrometric techniques. Porosities will also be calculated for the samples using measured values of particle and dry bulk densities. Bulk density will be calculated as the ratio of the dry weight to the volume of the core.

\subsection{Fire Effects on Geochemical Properties}

In addition to hydrophysical properties, burning and resulting post-fire conditions can alter the functioning of soils chemically through the effect on nutrient availability, mineralogy, $\mathrm{pH}$, and $\mathrm{C}: \mathrm{N}$ ratios. In a recent study of temporal patterns of solute loss following wildfires, Ferreira et al. (2005) investigated the hydrological implications of forest fire and the associated export of nutrients as solutes immediately after fire. They reported a rapid and widespread export of nutrients during the first 4 months following the wildfire. The amount of nutrients lost decreased gradually over those 4 months in response to the exhaustion of the ash source. After this period, nutrient peak losses occurred only in response to extreme rainfall events. One the tasks of this test will therefore be to quantify the changes in soil chemical properties following the fire.

\subsubsection{Fire Effects on Chemical Properties of Soil Extracts}

Wildfires can impact the availability and leaching of soil chemicals during the rainy season. Published reports suggest that high temperatures generated can remove virtually all near-surface soil organic matter thereby altering the cation exchange capacity of the soils with this type of alteration extending as deep as $80 \mathrm{~mm}$ (Graham et al. 2007). The availability of many nutrients is also very sensitive to changes in $\mathrm{pH}$, which has been shown to change following wildfire. In fact, soil $\mathrm{pH}$ and cation nutrients have been reported to increase immediately following burning (Covington et al. 1991, Marion et al. 1991, Bauhus et al. 1993) and the effect typically remains for one to several years. Soil samples will be collected pre- and post-burn for chemical characterization using a suite of standard tests. Measurements of $\mathrm{pH}$ will be made on 1:1 extracts of soil and distilled water incubated overnight at room temperature. In addition, electrical conductivity and total hardness will be measured. In order to investigate fire effects on nutrients, samples will be collected at the $0 \mathrm{~cm}-5 \mathrm{~cm}$ and $5 \mathrm{~cm}-10 \mathrm{~cm}$ depths immediately before and after the fire. Soil nutrient status will be characterized by determining ammonium and nitrate in $2 \mathrm{M}$ potassium chloride extractions, whereas soil exchangeable potassium will be determined from $1 \mathrm{~N}$ ammonium acetate extractions. The concentrations of macro nutrients, like $\mathrm{P}$ and $\mathrm{N}$, as total phosphorus, and $\mathrm{NH}_{4}{ }^{+}, \mathrm{NO}_{3}{ }^{-}$, as well as various elements, such as $\mathrm{Na}, \mathrm{K}, \mathrm{Mg}$, and $\mathrm{Ca}$, will be measured in the extracts.

Water extracts will be analyzed for anions using an ion chromatograph while cations will be determined by an inductively coupled plasma techniques. Fluoride, chloride, nitrite, nitrate phosphate, sulfate, and oxalate will be separated on a Dionex AS4A column with an eluent of $1.75 \mathrm{mM} \mathrm{NaHCO}_{3} /$ $1.85 \mathrm{mM} \mathrm{Na}_{2} \mathrm{CO}_{3}$ and measured using a conductivity detector following PNL-ALO-212, Rev. 1, which is based on U.S. Environmental Protection Agency (EPA) Method 9056, "Determination of Inorganic Anions by Ion Chromatography,” found in SW-846, "Test Methods for Evaluating Solid Waste, Physical/ Chemical Methods,” that can be accessed online at http://www.epa.gov/epaoswer/hazwaste/test/sw846.htm (EPA 1994). Cation analysis will be performed using an inductively coupled plasma unit. High-purity calibration standards will be used to generate calibration curves and to verify continuing calibration during the analysis run. If necessary, dilutions will be made of each to ensure that the analysis falls within the linear calibration range of the instrument. Details are found in EPA Method 6010B, "Inductively Coupled 
Plasma-Atomic Emission Spectrometry," in the aforementioned online version of SW-846 (EPA 1996). Samples will be analyzed for $\mathrm{Na}^{+}, \mathrm{K}^{+}, \mathrm{Ca}^{2+}, \mathrm{Mg}^{2+}$, and $\mathrm{Sr}^{2+}$. We anticipate differences in the concentrations of the various elements as well as in the physical properties $(\mathrm{pH}$, conductivity, and hardness) of the extracts due to the fire.

\subsubsection{Fire Effects on Mineralogy and Soil Genesis}

Surveys of mixed forests after severe burn have shown that spatial variations in thermally altered soil correlate well with differences in plant density. Deposits of white ash, composed largely of calcite, have been observed covering as much as $25 \%$ of the land surface in places where coarse fuel items were fully combusted (Goforth et al. 2005). A common and visually obvious alteration is the change in soil color from the yellow brown characteristic of goethite to reddish colors imparted by maghemite or hematite. These changes have been observed as deep as $60 \mathrm{~mm}$ (average $8 \mathrm{~mm}$ ). Concomitant increases in magnetic susceptibility indicate that maghemite is an iron oxide phase produced by this thermal process (Graham et al. 2007). The reddened soils had magnetic susceptibilities that were three to seven times greater than surrounding soils, within the burned area, that didn't exhibit a color change. Changes in silicate mineralogy have also been observed and include the decomposition of kaolin and the dehydroxylation and collapse of vermiculite and chlorite.

To determine the effects of fire on mineralogy and soil genesis in engineered ecosystems like barriers, the mineralogy of the whole soil and narrow sieve fractions will be determined by XRD techniques. Each sample will be ground into a fine powder using a mortar and pestle. These powders will then be side packed into aluminum sample holders for analysis. Samples will be analyzed using a Scintag XRD unit, equipped with a Pelter thermoelectrically cooled detector and a copper X-ray tube. X-ray patterns were recorded from $2^{\circ}$ to $65^{\circ} 2 \theta$ increments with a dwell time of 2 seconds. Patterns will be stored electronically and processed using the JADE ${ }^{\circledR}$ XRD pattern processing software. The mineral phases will be identified based on mineral powder diffraction files published by the JCPDS International Center for Diffraction Data. A semi quantification of mineral phases in the whole rock sediment samples will be obtained by the whole pattern-fitting technique provided by JADE $®$ XRD pattern processing software. The software uses a non-linear least-square optimization to fit a diffraction model to the data.

\subsubsection{Specific Surface Area}

The specific surface area is a measure of the exposed surface of a solid sample on the molecular scale and is important for the calculation of sorption properties. Changes in specific surface area have been reported following exposure of soils to elevated temperatures. Specific surface area will be measured on 12 samples using a Quantachrome Autosorb 6-B gas sorption surface area analyzer. The Monosorb is a direct-reading dynamic-flow surface-area analyzer that uses a single-point Brunauer-Emmett-Teller method to determine the surface area (Brunauer et al. 1938). Standard surface area reference materials will be used to calibrate the instrument over the anticipated range of surface areas. Representative samples will be weighed (to an accuracy of $0.001 \mathrm{~g}$ ) and dried overnight using a heating mantle. The Autosorb measures the quantity of a gas adsorbed on a solid surface when it is cooled, with liquid nitrogen, by sensing the change in thermal conductivity of a flowing mixture of an adsorbate (nitrogen) and an inert (helium) carrier gas. With nitrogen and helium, the surface area can be determined down to $0.1 \mathrm{~m}^{2}$. 


\subsection{Post-fire Stimulation of Biogenic $\mathrm{CO}_{2}$ Emissions}

In addition to the impacts on hydraulic properties, fire could become an important factor in barrier function by altering soil organic matter turnover. For example, Fierro et al. (2007) measured soil $\mathrm{CO}_{2}$ emissions over an annual cycle on burned and unburned sites in a Mediterranean shrub land subjected to experimental fire. They observed high spatial variability in $\mathrm{CO}_{2}$ effluxes in both control and burnt plots with control plot "hot spots' contributing 33\% to annual soil $\mathrm{CO}_{2}$ emission and those in burnt plots contributing 54.1\%. There was no relationship between temperature and $\mathrm{CO}_{2}$ effluxes, but soil water availability appeared to be the main factor affecting field $\mathrm{CO}_{2}$ effluxes from the burned plots. Thus, the long-term conservation of carbon may be important to the function of barriers. To quantify this potential, measurements of the impact of fire on the efficiency of soil microflora to conserve carbon will be assessed.

The efflux of soil $\mathrm{CO}_{2}$ will commence two days after the experimental fire and will continue for one year after the fire with measurements to be taken twice per month. Measurements will be made using the static chamber technique (Rolston 1994, Fierro et al. 2007). The chamber consists of a $20 \mathrm{~cm}$ id. PVC tube with a screw cap equipped with a gas sampling port that is plugged with a rubber septum. The rubber septum allows convenient sampling of any gas collecting in the headspace after the tube is inserted into the soil. The tube will be inserted to a depth of about $3 \mathrm{~cm}$, sealed, and allowed to collect gas over a 30 minute period. Four chambers will be placed on each plot and measurements will be made at the same time of the day during sampling events, around 12:00 noon, when the thermal gradient is near zero. Soil temperatures at a depth of $5 \mathrm{~cm}$ will be measured at the time of gas sampling, before closing the static chamber, and water content will be measured by TDR. During each sampling event, a gas sample will be taken at time zero and again after 30 minutes. Gas samples will be injected under pressure into vacuutainers (evacuated airtight tubes) that are self-sealing once the needles are removed from the rubber cap. Gas samples will be analyzed in the laboratory using a gas chromatograph within a few hours of collection.

Soil samples will be collected at the time of gas sampling from a point adjacent to the chamber for analysis of carbon and nitrogen content. Mineral nitrogen as ammonium and nitrate will be determined on soil water extracts using ion specific electrodes for $\mathrm{NH}_{4}{ }^{+}$and $\mathrm{NO}_{3}{ }^{-}$. The soil samples will be extracted with $0.5 \mathrm{M} \mathrm{K}_{2} \mathrm{SO}_{4}$ using a soil to extractant ratio of one to four. Organic carbon content will be determined using the loss on ignition method (Nelson and Sommers 1982). A subsample of 0.5 gm passed through a 100 - 140 -mesh sieve will be heated to $500^{\circ} \mathrm{C}$ for two hours in a muffle furnace. The organic carbon content, $\mathrm{C}_{\text {org }}$, is assumed to be $58 \%$ of total organic matter. The fumigation-incubation method will be used to determine the microbial carbon, $\mathrm{C}_{\text {mic }}$ (Jenkinson and Powlson 1976). The soil potential respiration will be measured in the laboratory at $55 \%$ of the soil water holding capacity at a temperature of $25^{\circ} \mathrm{C}$ using $\mathrm{NaOH}$ absorption followed by titration with $\mathrm{HCl}$ (Froment 1972). The activity of microorganisms for the control and burnt plots will be expressed as a metabolic quotient $\left(q \mathrm{CO}_{2}, \mathrm{mg} \mathrm{CO}_{2^{-}}\right.$ $\mathrm{C} \mathrm{mg}^{-1} \mathrm{C}_{\text {mic }} \mathrm{d}^{-1}$ ), whereas the rate of organic carbon mineralization will be expressed as the coefficient of endogenous mineralization (CEM; mg $\mathrm{CO}_{2}-\mathrm{C} \mathrm{mg}^{-1} \mathrm{C}_{\text {org }} \mathrm{d}^{-1}$ ). Geostatistical methods will be used to analyze the data and develop relationships to fire characteristics, soil properties, and plant distributions. 



\subsection{Data Collection, Management, Analysis, and Interpretation}

Data collection will commence prior to the burn to characterize the initial conditions and will continue during and after the burn. Data collection after the burn will become part of the annual work scope that covers barrier monitoring. The current scope includes an annual topographic survey to document changes in elevation, including the effects of wind and water erosion, a stability survey, to document changes in the rip rap side slope, water balance monitoring, to quantify the components of the water balance, including runoff and soil loss, and a plant and animal survey to document changes in plant and animal habitat and use on the barrier. All of the post-fire data collection activities planned for the current test will be incorporated into the annual monitoring plan.

The existing barrier monitoring database will be extended to permit storage, analysis, and management of data collected during the fire-effects test. All data will be stored as the original raw data in separate files from the processed and interpreted data. All field and lab data will be entered as ASCII (text) files that are software and operating system independent. Data processing and analysis will be performed using Microsoft ${ }^{\circledR}$ Excel ${ }^{\circledR}$ and files will be electronically in the existing database. Subtask leads will provide hard copies of data collection sheets and field/laboratory notebooks to the project manager for storage in the project files. The following sample identifier information must be included, as a minimum, in the database:

- Sample spatial location

- Sampling time

- Sampling date

- Analysis date

- Laboratory name

- Procedure name/number

- Variable measured, value, and standard error

- Measurement unit.

The experimental design is such that geostatistical methods can be applied to the analysis of spatial and temporal changes in soil properties and vegetation status following the fire. Geostatistical methods will be used to identify correlation length scales based on the theory of regionalized variables.

A Memorandum of Understanding has been established to identify the organizational roles and responsibilities for work supporting the controlled burn of the northern half of the Hanford Prototype Barrier located in 200 East Area and for the collection, analysis, and interpretation of data. PNNL is responsible for the overall data collection effort and will focus on physical, hydrologic, and geochemical data. Some data collection and interpretation activities have been subcontracted to WSU. WSU is responsible for the collection of data related to plants and animals and the progression of the fire. Table 4.1 provides a summary of the project tasks, responsibilities, data types and collection methods. A report documenting the pre-burn conditions, the actual burn, and proposed plans for post-burn monitoring of the barrier will be integrated with the annual barrier monitoring report to be issued by the end of October, 2008. 
Table 4.1. Summary of Tasks, Responsibilities, Data Types, and Data Collection Methods

\begin{tabular}{|c|c|c|c|c|c|c|c|}
\hline $\begin{array}{c}\text { Task } \\
\text { Description }\end{array}$ & $\begin{array}{l}\text { Who is Task } \\
\text { Lead }\end{array}$ & $\begin{array}{l}\text { What Type of Data/Number of } \\
\text { Measurements/Action Required }\end{array}$ & $\begin{array}{l}\text { When } \\
\text { Will } \\
\text { Data Be } \\
\text { Collected }\end{array}$ & $\begin{array}{l}\text { Where Will Data Be } \\
\text { Collected/Activity } \\
\text { Will Be Conducted }\end{array}$ & $\begin{array}{l}\text { Why is Data Being } \\
\text { Collected/Activity } \\
\text { Being Performed }\end{array}$ & $\begin{array}{l}\text { How Will Data Be Collected/Activity } \\
\text { Will Be Completed }\end{array}$ & $\begin{array}{l}\text { Test } \\
\text { Plan } \\
\text { Section }\end{array}$ \\
\hline \multicolumn{8}{|c|}{ GENERAL } \\
\hline $\begin{array}{l}\text { Issue Test } \\
\text { Plan }\end{array}$ & $\begin{array}{l}\text { A. Ward - PNNL } \\
\text { S. Link - WSU }\end{array}$ & $\begin{array}{l}\text { Types of data and number of measurements } \\
\text { summarized below }\end{array}$ & $\begin{array}{l}\text { Pre- } \\
\text { Burn }\end{array}$ & $\begin{array}{l}\text { Locations } \\
\text { summarized below }\end{array}$ & $\begin{array}{l}\text { Determine } \\
\text { impacts of fire on } \\
\text { barrier } \\
\text { performance }\end{array}$ & $\begin{array}{l}\text { Types of instrumentation and methods } \\
\text { summarized below }\end{array}$ & $N A$ \\
\hline $\begin{array}{l}\text { Issue project } \\
M O U\end{array}$ & $\begin{array}{l}\text { G. Berlin - FH } \\
\text { J. Cammann - } \\
\text { FGG }\end{array}$ & $\begin{array}{l}\text { Establish MOU between supporting FH } \\
\text { organizations (D\&D, S\&GRP, Fire } \\
\text { Department) and PNNL, WSU, and CH2M } \\
\text { HILL (BY Tank Farm Operations) }\end{array}$ & $\begin{array}{l}\text { Pre- } \\
\text { Burn }\end{array}$ & $\begin{array}{l}\text { Issued as a separate } \\
\text { document from the } \\
\text { test plan }\end{array}$ & $\begin{array}{l}\text { Establish project } \\
\text { responsibilities; } \\
\text { ensure proper } \\
\text { coordination and } \\
\text { interfaces }\end{array}$ & $\begin{array}{l}\text { Responsibilities of each of the supporting } \\
\text { organizations will be delineated and written } \\
\text { concurrence will be obtained via the MOU }\end{array}$ & 1.3 \\
\hline $\begin{array}{l}\text { Conduct } \\
\text { NEPA }\end{array}$ & $\begin{array}{l}\text { J. Downs - } \\
\text { PNNL }\end{array}$ & $\begin{array}{l}\text { Cultural and biological review in accordance } \\
\text { with the provisions of Categorical Exclusion } \\
\text { (CX) B3.11 }\end{array}$ & $\begin{array}{l}\text { Pre- } \\
\text { Burn }\end{array}$ & $\begin{array}{l}\text { On barrier surface } \\
\text { and vicinity }\end{array}$ & $\begin{array}{l}\text { Comply with } \\
\text { NEPA } \\
\text { requirements and } \\
\text { conditions of } C X \\
\text { B3.11 }\end{array}$ & $\begin{array}{l}\text { Per } 36 \text { CFR Part 800, Subpart B, 800.3.a, the } \\
\text { DOE-RL Cultural Resources Program has } \\
\text { determined that this project is not the type of } \\
\text { undertaking with potential to cause effects to } \\
\text { historic properties and no further actions are } \\
\text { required }\end{array}$ & 3.1 \\
\hline $\begin{array}{l}\text { Site } \\
\text { Preparation }\end{array}$ & $\begin{array}{l}\text { A. Ward - PNNL } \\
\text { S. Link - WSU } \\
\text { B. Atkinson - FH } \\
\text { D. Hughes - FH }\end{array}$ & $\begin{array}{l}\text { Tumbleweed removal and loading on barrier } \\
\text { surface; instrument cable and instrument } \\
\text { protection; install fabric fence along east side } \\
\text { of barrier (post-burn); pre-burn notification } \\
\text { site-wide }\end{array}$ & $\begin{array}{l}\text { Pre- } \\
\text { Burn } \\
\text { Post- } \\
\text { Burn }\end{array}$ & $\begin{array}{l}\text { Tumbleweed } \\
\text { removal on east } \\
\text { side of barrier } \\
\text { along BY Tank } \\
\text { Farm fence and } \\
\text { placement on } \\
\text { barrier surface; } \\
\text { instrument cables } \\
\text { running from data } \\
\text { loggers, solar } \\
\text { panels, and other } \\
\text { equipment }\end{array}$ & $\begin{array}{l}\text { Fuel for fire; } \\
\text { protect existing } \\
\text { instruments and } \\
\text { cables; install new } \\
\text { instruments; keep } \\
\text { post-burn } \\
\text { tumbleweeds from } \\
\text { BY Tank Farm }\end{array}$ & $\begin{array}{l}\text { Coordinate with FH Site Services organization for } \\
\text { tumbleweed removal and placement; instrument } \\
\text { cables to be hand-buried along stepping stone } \\
\text { walkways on barrier surface; PNNL to arrange for } \\
\text { fabric fence (post-burn); site-wide notifications } \\
\text { and press releases by FH and DOE-RL }\end{array}$ & 3.2 \\
\hline $\begin{array}{l}\text { Conduct } \\
\text { Controlled } \\
\text { Burn }\end{array}$ & $\begin{array}{l}\text { L. Click - HFD } \\
\text { J. Keelin - HFD }\end{array}$ & $\begin{array}{l}\text { Issue site-wide notification of barrier burn } \\
\text { activity; conduct controlled burn of northern } \\
\text { portion of barrier surface; maintain fire watch } \\
\text { after burn, as needed }\end{array}$ & $\begin{array}{l}\text { Actual } \\
\text { burn }\end{array}$ & On barrier surface & $\begin{array}{l}\text { Determine } \\
\text { impacts of fire on } \\
\text { barrier } \\
\text { performance }\end{array}$ & $\begin{array}{l}\text { In accordance with Hanford Fire Department } \\
\text { procedures, protocols, permits, and other applicable } \\
\text { requirements }\end{array}$ & 3.4 \\
\hline $\begin{array}{l}\text { Issue Annual } \\
\text { Report }\end{array}$ & $\begin{array}{l}\text { A. Ward - PNNL } \\
\text { S. Link - WSU }\end{array}$ & $\begin{array}{l}\text { Issue report documenting pre-burn conditions } \\
\text { and proposed plans for post-burn monitoring } \\
\text { of the barrier }\end{array}$ & $\begin{array}{l}\text { Post- } \\
\text { Burn }\end{array}$ & $\begin{array}{l}\text { Issue as a separate } \\
\text { PNNL document }\end{array}$ & $\begin{array}{l}\text { Establish a pre- } \\
\text { burn baseline for } \\
\text { post-burn } \\
\text { comparisons to } \\
\text { determine impacts } \\
\text { on barrier } \\
\text { performance }\end{array}$ & $\begin{array}{l}\text { Pre-burn activities funded as part of FH Hanford } \\
\text { Prototype Barrier cost account; post-burn } \\
\text { monitoring to be conducted as funding permits in } \\
\text { accordance with CHPRC priorities }\end{array}$ & 4.0 \\
\hline
\end{tabular}


Table 4.1. (contd)

\begin{tabular}{|c|c|c|c|c|c|c|c|}
\hline $\begin{array}{c}\text { Task } \\
\text { Description }\end{array}$ & $\begin{array}{l}\text { Who is Task } \\
\text { Lead }\end{array}$ & $\begin{array}{l}\text { What Type of Data/Number of } \\
\text { Measurements/Action Required }\end{array}$ & $\begin{array}{l}\text { When } \\
\text { Will } \\
\text { Data Be } \\
\text { Collected }\end{array}$ & $\begin{array}{l}\text { Where Will Data Be } \\
\text { Collected/Activity } \\
\text { Will Be Conducted }\end{array}$ & $\begin{array}{l}\text { Why is Data Being } \\
\text { Collected/Activity } \\
\text { Being Performed }\end{array}$ & $\begin{array}{l}\text { How Will Data Be Collected/Activity Will Be } \\
\text { Completed }\end{array}$ & $\begin{array}{l}\text { Test } \\
\text { Plan } \\
\text { Section }\end{array}$ \\
\hline \multicolumn{8}{|c|}{ BARRIER MONITORING } \\
\hline $\begin{array}{l}\text { Physical } \\
\text { Properties }\end{array}$ & $\begin{array}{l}\text { Andy Ward - } \\
\text { PNNL }\end{array}$ & $\begin{array}{l}36 \text { measurements (soil cores) for the } \\
\text { following properties: structure, porosity, } \\
\text { color, water repellency, wind/water erosion } \\
\text { (runoff, sediment yields), inflation/deflation, } \\
\text { water retention, thermal conductivity, soil } \\
\text { temperature, moisture, matric potential, } \\
\text { evaporation, bulk density, electrical } \\
\text { conductivity, specific surface area, hydraulic } \\
\text { conductivity, soil texture, particle size, soil } \\
\text { mineralogy }\end{array}$ & $\begin{array}{l}\text { Pre- } \\
\text { Burn } \\
\text { Post- } \\
\text { Burn }\end{array}$ & $\begin{array}{l}\text { At mid-point of } \\
\text { each } 6 \mathrm{~m} X \mathrm{Xm} \text { plot; } \\
\text { north side of } \\
\text { barrier }\end{array}$ & $\begin{array}{l}\text { Determine } \\
\text { impacts of fire on } \\
\text { soil physical } \\
\text { properties and } \\
\text { resultant barrier } \\
\text { performance }\end{array}$ & $\begin{array}{l}\text { Structure by visual observation; porosity by lab } \\
\text { procedure; color by Munsell book; water } \\
\text { repellency by Water Drop Penetration Time Test; } \\
\text { wind/water erosion by runoff flumes, erosion pins, } \\
\text { and turbidity measurements; inflation/deflation by } \\
\text { gravel content samples; water retention by ASTM } \\
\text { pressure plate method; thermal conductivity by } \\
\text { thermal TDR; soil temperature by thermistors and } \\
\text { HDU; moisture by TDR, neutron hydroprobe, and } \\
\text { gravimetric; matric potential by HDU; evaporation } \\
\text { by water balance calculations; bulk density by } \\
\text { Troxler probe; electrical conductivity by saturated } \\
\text { paste extract; specific surface area by BET } \\
\text { nitrogen absorption; hydraulic conductivity by } \\
\text { Guelph tension infiltrometer; soil texture by } \\
\text { hydrometer; particle size by wet/dry sieving and } \\
\text { hydrometer; soil mineralogy by XRD }\end{array}$ & 3.5 \\
\hline $\begin{array}{l}\text { Geochemical } \\
\text { Properties }\end{array}$ & $\begin{array}{l}\text { Andy Ward - } \\
\text { PNNL }\end{array}$ & $\begin{array}{l}36 \text { measurements (soil cores) for the } \\
\text { following properties: pH; nitrogen, } \\
\text { phosphorus, potassium, carbon, organic } \\
\text { matter, soil water extract hardness, exchange } \\
\text { capacity (anion/cation) }\end{array}$ & $\begin{array}{l}\text { Pre- } \\
\text { Burn } \\
\text { Post- } \\
\text { Burn }\end{array}$ & $\begin{array}{l}\text { At mid-point of } \\
\text { each } 6 \mathrm{~m} X \mathrm{Xm} \text { plot; } \\
\text { north side of } \\
\text { barrier }\end{array}$ & $\begin{array}{l}\text { Determine } \\
\text { impacts of fire on } \\
\text { soil geochemical } \\
\text { properties and } \\
\text { resultant barrier } \\
\text { performance }\end{array}$ & $\begin{array}{l}\text { pH by lab procedure and pH meter; nitrogen, } \\
\text { phosphorus, potassium, and carbon by ICP-MS; } \\
\text { organic matter by lab muffle furnace (loss on } \\
\text { ignition); soil water extract hardness by lab } \\
\text { method measuring carbonate; exchange capacity } \\
\text { by lab method (ammonium acetate) }\end{array}$ & 3.6 \\
\hline $\begin{array}{l}\text { Biological } \\
\text { Properties }\end{array}$ & $\begin{array}{l}\text { Andy Ward - } \\
\text { PNNL }\end{array}$ & $\begin{array}{l}36 \text { measurements (soil cores) for the } \\
\text { following properties: microbes, microbial } \\
\text { composition, microbial carbon, microbial } \\
\text { carbon dioxide generation, coefficient of } \\
\text { endogenous mineralization, soil cryptogam } \\
\text { (density/type), }\end{array}$ & $\begin{array}{l}\text { Pre- } \\
\text { Burn } \\
\text { Post- } \\
\text { Burn }\end{array}$ & $\begin{array}{l}\text { At mid-point of } \\
\text { each } 6 \mathrm{~m} X 6 \mathrm{~m} \text { plot; } \\
\text { north side of } \\
\text { barrier }\end{array}$ & $\begin{array}{l}\text { Determine } \\
\text { impacts of fire on } \\
\text { soil biological } \\
\text { properties and } \\
\text { resultant barrier } \\
\text { performance }\end{array}$ & $\begin{array}{l}\text { Microbes by lab culture; microbial composition by } \\
\text { lab culture; microbial carbon by static chamber } \\
\text { and GC; microbial carbon dioxide generation by } \\
\text { static chamber and GC; coefficient of endogenous } \\
\text { mineralization by lab method; soil cryptogam by } \\
\text { lab method }\end{array}$ & 3.7 \\
\hline $\begin{array}{l}\text { Rainfall } \\
\text { Simulation } \\
\text { Test }\end{array}$ & $\begin{array}{l}\text { Andy Ward - } \\
\text { PNNL }\end{array}$ & Soil moisture content and runoff erosion rates & $\begin{array}{l}\text { Post- } \\
\text { Burn }\end{array}$ & $\begin{array}{l}\text { Runoff erosion } \\
\text { flume on barrier } \\
\text { surface }\end{array}$ & $\begin{array}{l}\text { Determine impact } \\
\text { of fire and } \\
\text { vegetation removal } \\
\text { on water } \\
\text { infiltration and } \\
\text { runoff erosion }\end{array}$ & $\begin{array}{l}\text { Follow } 1000 \text {-year storm protocol using overhead } \\
\text { irrigation system; soil moisture by neutron } \\
\text { hydroprobe, TDR, and gravimetric; runoff erosion } \\
\text { by flumes, pins, and turbidity }\end{array}$ & 3.5 \\
\hline
\end{tabular}


Table 4.1. (contd)

\begin{tabular}{|c|c|c|c|c|c|c|c|}
\hline $\begin{array}{c}\text { Task } \\
\text { Description }\end{array}$ & $\begin{array}{l}\text { Who is Task } \\
\text { Lead }\end{array}$ & $\begin{array}{l}\text { What Type of Data/Number of } \\
\text { Measurements/Action Required }\end{array}$ & $\begin{array}{l}\text { When } \\
\text { Will } \\
\text { Data Be } \\
\text { Collected }\end{array}$ & $\begin{array}{l}\text { Where Will Data Be } \\
\text { Collected/Activity } \\
\text { Will Be Conducted }\end{array}$ & $\begin{array}{l}\text { Why is Data Being } \\
\text { Collected/Activity } \\
\text { Being Performed }\end{array}$ & $\begin{array}{l}\text { How Will Data Be Collected/Activity Will Be } \\
\text { Completed }\end{array}$ & $\begin{array}{l}\text { Test } \\
\text { Plan } \\
\text { Section }\end{array}$ \\
\hline & & & \multicolumn{5}{|c|}{ VEGETATION MONITORING } \\
\hline $\begin{array}{l}\text { Fuel Load } \\
\text { and Plant } \\
\text { Water } \\
\text { Content }\end{array}$ & $\begin{array}{l}\text { Steve Link - } \\
\text { WSU }\end{array}$ & $\begin{array}{l}\text { Wet biomass (15 sagebrush plants), oven } \\
\text { dried biomass (15 sagebrush plants), canopy } \\
\text { height (45 sagebrush plants), canopy greatest } \\
\text { diameter (45 sagebrush plants), canopy } \\
\text { diameter } 90 \text { degrees to greatest (45 sagebrush } \\
\text { plants), sagebrush density (144 cells @ } 3 m X \\
\text { 3m), Russian thistle cover (144 cells @ 3m X } \\
\text { 3m), Russian thistle wet biomass (15 cells @ } \\
3 m X 3 m), \text { Russian thistle oven dried biomass } \\
\text { (15 cells @ 3m X 3m; } 5 \text { subsamples) }\end{array}$ & $\begin{array}{l}\text { Pre- } \\
\text { Burn } \\
\text { Post- } \\
\text { Burn }\end{array}$ & $\begin{array}{l}\text { Oven dried biomass } \\
\text { determined at WSU } \\
\text { labs; all other } \\
\text { measurements on } \\
\text { barrier surface }\end{array}$ & $\begin{array}{l}\text { Determine fuel } \\
\text { load and plant } \\
\text { water content in } \\
\text { support of fire and } \\
\text { subsequent } \\
\text { analyses }\end{array}$ & $\begin{array}{l}\text { Biomass by calibrated scale; canopy height and } \\
\text { diameter by measuring tape; plant density by } \\
\text { count; plant cover by visual observation }\end{array}$ & 3.3 \\
\hline $\begin{array}{l}\text { Characterize } \\
\text { Natural Area }\end{array}$ & $\begin{array}{l}\text { Steve Link - } \\
\text { WSU }\end{array}$ & $\begin{array}{l}\text { Sagebrush density (3 sites; } 30 \text { cells @ 3m X } \\
\text { 3m), cover ( } 3 \text { sites; } 30 \text { cells @ 3m X 3m), soil } \\
\text { cryptogam ( } 3 \text { sites; } 30 \text { cells @ } 3 m X 3 m) \text {, seed } \\
\text { bank ( } 3 \text { sites; } 30 \text { cells @ } 3 m X 3 m) \text {, and leaf } \\
\text { area index ( } 3 \text { sites; } 30 \text { cells @ 3m X 3m) } \\
\text { measurements in low, medium, and high } \\
\text { density plant stands }\end{array}$ & $\begin{array}{l}\text { Pre- } \\
\text { Burn } \\
\text { Post- } \\
\text { Burn }\end{array}$ & $\begin{array}{l}\text { McGee Ranch and } \\
\text { other nearby silt } \\
\text { loam soil sites }\end{array}$ & $\begin{array}{l}\text { Verify that plant } \\
\text { density on barrier } \\
\text { is representative } \\
\text { of surrounding } \\
\text { natural plant } \\
\text { communities; } \\
\text { support thinning, } \\
\text { as required }\end{array}$ & $\begin{array}{l}\text { Sagebrush density by count; cover by visual } \\
\text { observation; cryptogams by WSU herbarium } \\
\text { dissecting scope; seed bank by WSU greenhouse; } \\
\text { leaf area index by Decagon plant canopy analyzer }\end{array}$ & 3.3 \\
\hline $\begin{array}{l}\text { Characterize } \\
\text { Barrier } \\
\text { Surface }\end{array}$ & $\begin{array}{l}\text { Steve Link - } \\
\text { WSU }\end{array}$ & $\begin{array}{l}\text { Plant, soil, cryptogam species (complete } \\
\text { inspection); canopy height ( } 25 \text { sagebrush } \\
\text { plants); canopy greatest diameter ( } 25 \\
\text { sagebrush plants); canopy diameter } 90 \\
\text { degrees to greatest ( } 25 \text { sagebrush plants); } \\
\text { shrub survival and age class ( } 30 \text { cells @ } 3 m \text { X } \\
3 m \text { on each half of barrier); mammals, birds, } \\
\text { insects, and arachnids (10 traps on each half } \\
\text { of barrier); animal sign ( } 30 \text { cells @ } 3 m X \\
3 m) ; \text { root density (6 root tubes in each half of } \\
\text { barrier); seed bank ( } 30 \text { samples from each } \\
\text { half of barrier); wind erosion ( } 30 \text { erosion } \\
\text { pins); plant water relations (6 shrubs from } \\
\text { each half of barrier) }\end{array}$ & $\begin{array}{l}\text { Pre- } \\
\text { Burn } \\
\text { Post- } \\
\text { Burn }\end{array}$ & $\begin{array}{l}\text { Plant and soil } \\
\text { cryptogam species } \\
\text { determined on } \\
\text { barrier north and } \\
\text { south halves, and } \\
\text { north and west side } \\
\text { slopes; canopy } \\
\text { determined on } \\
\text { barrier south } \\
\text { surface; shrub } \\
\text { survival on barrier } \\
\text { north and south } \\
\text { halves; animals, } \\
\text { root density, seed } \\
\text { bank, and plant } \\
\text { water relations on } \\
\text { barrier north and } \\
\text { south halves; wind } \\
\text { erosion on barrier } \\
\text { north half }\end{array}$ & $\begin{array}{l}\text { Determine } \\
\text { presence and } \\
\text { impact of insects } \\
\text { and small } \\
\text { burrowing } \\
\text { mammals on } \\
\text { water infiltration; } \\
\text { establish plant } \\
\text { baseline prior to } \\
\text { burn }\end{array}$ & $\begin{array}{l}\text { Plant and soil cryptogam species by visual } \\
\text { observation and WSU herbarium; plant canopy } \\
\text { height and diameter by measuring tape; shrub } \\
\text { survival and age class by visual observation; } \\
\text { animal species by Sherman live traps, pitfall traps, } \\
\text { and collections; animal sign by visual observation; } \\
\text { root density by root camera; seed bank by WSU } \\
\text { greenhouse; wind erosion by erosion pins; plant } \\
\text { water relations by pressure bomb }\end{array}$ & 3.3 \\
\hline
\end{tabular}


Table 4.1. (contd)

\begin{tabular}{|c|c|c|c|c|c|c|c|}
\hline $\begin{array}{c}\text { Task } \\
\text { Description }\end{array}$ & $\begin{array}{l}\text { Who is Task } \\
\text { Lead }\end{array}$ & $\begin{array}{l}\text { What Type of Data/Number of } \\
\text { Measurements/Action Required }\end{array}$ & $\begin{array}{l}\text { When } \\
\text { Will } \\
\text { Data Be } \\
\text { Collected }\end{array}$ & $\begin{array}{l}\text { Where Will Data Be } \\
\text { Collected/Activity } \\
\text { Will Be Conducted }\end{array}$ & $\begin{array}{c}\text { Why is Data Being } \\
\text { Collected/Activity } \\
\text { Being Performed }\end{array}$ & $\begin{array}{l}\text { How Will Data Be Collected/Activity Will Be } \\
\text { Completed }\end{array}$ & $\begin{array}{l}\text { Test } \\
\text { Plan } \\
\text { Section }\end{array}$ \\
\hline $\begin{array}{l}\text { Fire } \\
\text { Documentati } \\
\text { on }\end{array}$ & $\begin{array}{l}\text { Steve Link - } \\
\text { WSU }\end{array}$ & $\begin{array}{l}\text { Flame height ( } 5 \text { locations); temperatures }(63 \\
\text { sensors every } 2 \text { seconds for } 24 \text { hours at }-1 \mathrm{~cm} \\
\text { to }-2 \mathrm{~cm} \text {, surface, }+1 \mathrm{~cm},+10 \mathrm{~cm},+30 \mathrm{~cm}, \\
+100 \mathrm{~cm} \text {, and }+200 \mathrm{~cm} \text {, timing (duration of } \\
\text { burn) }\end{array}$ & $\begin{array}{l}\text { During } \\
\text { burn }\end{array}$ & $\begin{array}{l}\text { Flame height at } 5 \\
\text { locations of surface; } \\
\text { temperatures } \\
\text { measured via } 4 \\
\text { towers in sagebrush, } \\
4 \text { towers in Russian } \\
\text { thistle, and } 1 \text { control } \\
\text { tower in unburned } \\
\text { area; tower } \\
\text { locations are at grids } \\
(2,18),(5,18) \text {, } \\
(8,18),(11,18) \text {, } \\
(2,23),(5,23) \text {, } \\
(8,23),(11,23) \text {, and } \\
(7,4)\end{array}$ & $\begin{array}{l}\text { Verify fire } \\
\text { simulation against } \\
\text { actual range fire } \\
\text { characteristics }\end{array}$ & $\begin{array}{l}\text { Flame height will be measured with } 2.5 \mathrm{~m} \text { metal } \\
\text { poles (marked in decimeters), visual observation, } \\
\text { and video camera; temperatures will be measured } \\
\text { with Type K thermocouples; timing will be the total } \\
\text { duration of the burn }\end{array}$ & 3.4 \\
\hline
\end{tabular}





\subsection{Equipment and Materials}

A variety of equipment and consumables will be required to prepare the site, characterize the pre-burn condition, conduct the test, and characterize post-fire conditions. Table 5.1 provides a summary of these items and the estimated cost. This list is by no means all inclusive but serves as a check list for the major items.

Table 5.1. Required Equipment and Materials and Estimated Costs for the Fire-effects Field Test

\begin{tabular}{|c|c|c|c|c|}
\hline $\begin{array}{c}\text { Activity } \\
\text { ID }\end{array}$ & Activity Description & Materials & Quantity & $\begin{array}{l}\text { Estimated } \\
\text { Cost }\end{array}$ \\
\hline \multirow[t]{4}{*}{2} & Site Preparation & Field Electronic Balance & 1 & $\$ 500.00$ \\
\hline & & Tenax 4 Ft. x 100 Ft. Orange Warning Barrier & 1 & $\$ 40.00$ \\
\hline & & Wooden Stakes & 25 & $\$ 30.00$ \\
\hline & & Pin Flags & 50 & $\$ 40.00$ \\
\hline \multirow[t]{7}{*}{3} & Initial Hydrophysical & & & \\
\hline & Conditions & Guelph Tension Infiltrometer & 25 & $\$ 1,200.00$ \\
\hline & & Soil Cores (for Sample Collection) & 200 & $\$ 500.00$ \\
\hline & & Ziploc Bags & 200 & $\$ 10.00$ \\
\hline & & Duct tape (seal samples) & 2 & $\$ 10.00$ \\
\hline & & GEMS2 Conductivity meter & 1 & $\$ 18,000.00$ \\
\hline & & Miscellaneous Chemicals & & $\$ 700.00$ \\
\hline \multirow[t]{2}{*}{5} & $\begin{array}{l}\text { Collect Plant Samples } \\
\text { for Lab Analysis }\end{array}$ & Plastic Bags & 200 & $\$ 25.00$ \\
\hline & & Meter Stick & 5 & $\$ 25.00$ \\
\hline 7 & Aerial Photos & Photographic Services & & $\$ 500.00$ \\
\hline \multirow[t]{8}{*}{9} & Site Instrumentation for & & & \\
\hline & Fire monitoring & Themocouple/Flame-height Towers (10 ft tall) & 9 & $\$ 800.00$ \\
\hline & & Themocouples & 64 & $\$ 13,400.00$ \\
\hline & & Themocouple Connectors & 64 & $\$ 371.00$ \\
\hline & & Themocouples Wire & 64 & $\$ 3,840.00$ \\
\hline & & HOBO Dataloggers & 64 & $\$ 4,050.00$ \\
\hline & & Digital Video Camera & 1 & $\$ 400.00$ \\
\hline & & Camera Tower & 1 & $\$ 500.00$ \\
\hline \multirow[t]{5}{*}{11} & Post-fire Characterization & Soil Cores (for Sample Collection) & 200 & $\$ 500.00$ \\
\hline & & Poly bottle for runoff sampling & 100 & $\$ 300.00$ \\
\hline & & ISCO Automatic Water/Sediment Sampler & 1 & $\$ 3,000.00$ \\
\hline & & Gas sampling Chambers and Syringes & 9 & $\$ 500.00$ \\
\hline & & Licor LI-840 Gas Analyzer & 1 & $\$ 6,000.00$ \\
\hline
\end{tabular}





\subsection{Schedule}

The schedule of activities through the end of FY 2008 is shown in Table 6.1. The schedule addresses major activities planned in FY 2008 to complete the barrier burn with post-burn monitoring activities to be conducted in FY 2009 and beyond. The planned work will include a number of pre-burn activities, including site preparation and documentation of initial hydrophysical conditions and vegetation status. The first activity, not shown on the schedule, was the development of this test plan, which provides the rationale for the test and describes the protocol and procedures by which the tests will be governed. Prior to the start of field work, the Hanford Cultural Resources Project (HCRP) will conduct a cultural resources review of the subject project and barrier site to determine whether project activities will adversely affect the site and/or adjacent historic properties. Site preparation will focus on protecting the existing monitoring infrastructure and may require the removal of some pieces of equipment, burying of cables/conduits, and the installation of thermal blankets where necessary. A number of field campaigns are planned to characterize the initial hydrophysical conditions. Lessons learned from this activity will be applied to the design of monitoring programs for future barriers.

A vegetation survey will be conducted to define sagebrush density, cover, and leaf area index in three communities in silt loam soils to cover the range of common density and cover (low, medium, and high) before the fire. Measurements will be conducted to determine soil moisture distributions and near-surface bulk density using a nuclear density gauge. Soil samples will be collected on a $3 \times 3 \mathrm{~m}$ grid to determine the particle size distribution, particularly gravel content and soil organic matter. Laboratory analysis of soils samples to determine nutrient status, elemental composition, and mineralogy will commence during the first week of September. Instrumentation of the site to facilitate fire monitoring will commence during the week of September 15, 2008, and should take 10-12 days to complete the installation and testing. The simulated fire will be conducted by the Hanford Fire Department and is scheduled to occur the weekend of September 26, 2008. A burn dry-run will be conducted to ensure all pre-burn activities have been completed. This will include a site walk-down to ensure coordination and integration of burn activities prior to placement of imported fuel. Post-fire sampling and characterization will commence on, or shortly after, September 29, 2008, and continue through FY 2009. Given the unique performance baseline data collected to date at the Hanford Prototype Barrier site, DOE representation for this project will continue to seek appropriate funding to continue post-burn monitoring for at least the next five years. Available funding will be identified in budget guidance provided by DOE to the Plateau Remediation Contractor. The proposed schedule for FY 2009 is shown in Table 6.2. Apart from the tasks associated with post-fire monitoring, primarily Post-Fire Soil Sampling and Analysis, these tasks are essentially identical to those performed for the last several 13 years. Activities beyond FY 2009 would likely follow the same format. 
Table 6.1. Schedule for Major Barrier Burn Activities Through End of FY 2008

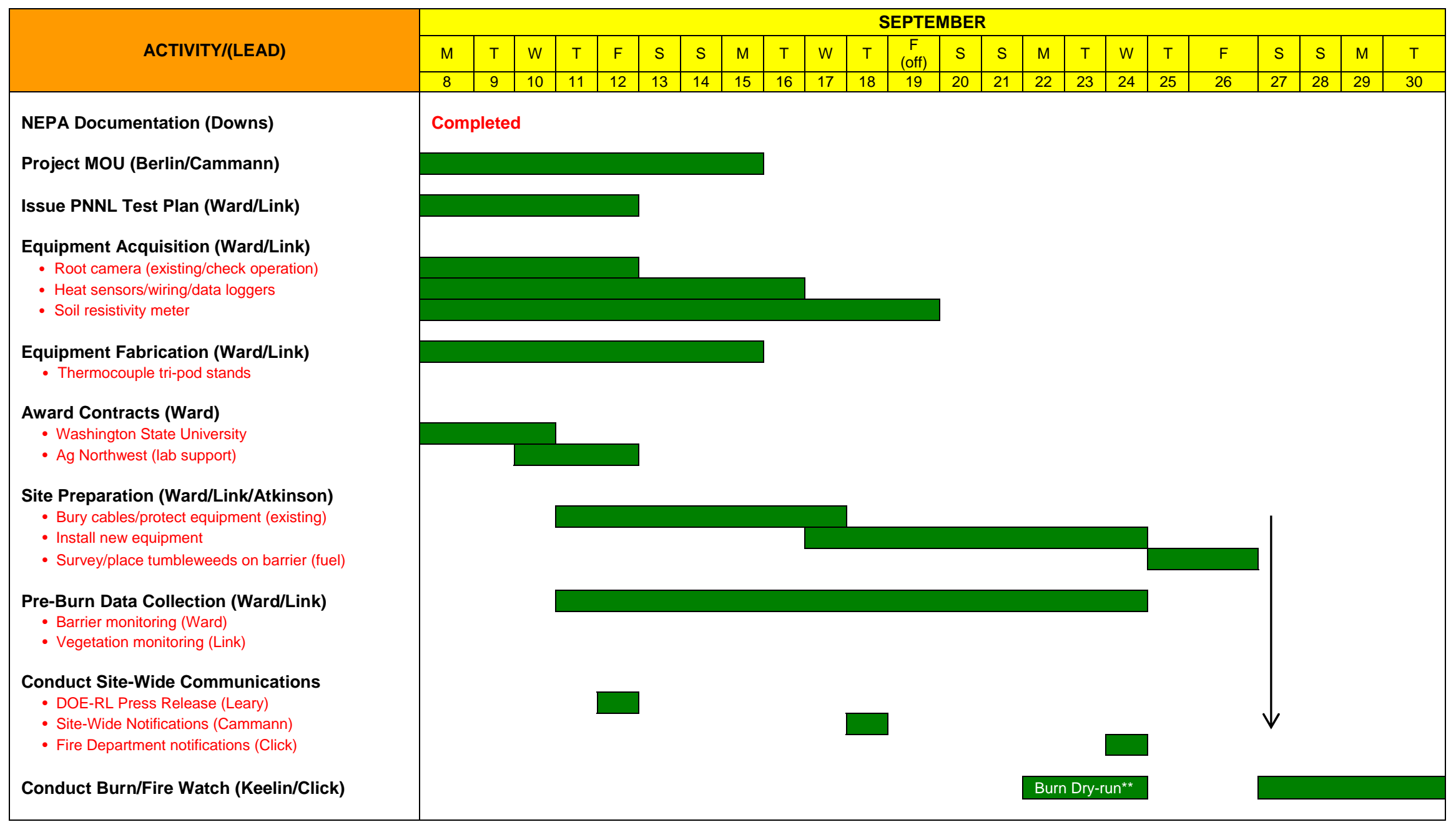

* Schedule addresses major activities planned in FY 2008 to complete barrier burn; post-burn monitoring activities will be conducted in FY 2009 , as funding permits.

** Burn dry-run to ensure all pre-burn activities have been completed; site walk-down to ensure coordination and integration of burn activities prior to placement of imported fuel 
Table 6.2. Schedule for Major Barrier Burn Activities Through End of FY 2008 (2 pages)

\begin{tabular}{|c|c|c|c|c|c|c|c|c|c|c|c|c|c|c|c|c|c|c|c|c|c|}
\hline SCHEDULE FOR & G ACTII & VIT & IE & 7 & $\mathrm{H}$ & C & $\mathrm{J}$ & $\mathrm{H}$ & El & L & $\mathrm{O}$ & $\mathrm{F}$ & Y & 0 & & & & & & & \\
\hline АСTIVITYIL EAD & October & & & ver & ibe & & & :er & & & & nu & & & & br & Iary & & & & \\
\hline ACIIVIIYI(LEAD) & \begin{tabular}{l|l|l|}
1 & 2 & 3 \\
\end{tabular} & 4 & 1 & 2 & 3 & 4 & 1 & 2 & 3 & & 1 & & 3 & & 1 & 2 & 3 & 4 & 1 & 2 & \begin{tabular}{|l|l|}
3 & 4 \\
\end{tabular} \\
\hline Post Fire Soil Sampling/Analysis & & & & & & & & & & & & & & & & & & & & & \\
\hline - Post-burn runoff Simulations & & & & & & & & & & & & & & & & & & & & & \\
\hline - Post-burn Infiltration Rates & & & & & & & & & & & & & & & & & & & & & \\
\hline - Hydrophysical Properties/Wettability Tests & & & & & & & & & & & & & & & & & & & & & \\
\hline - Biogenic $\mathrm{CO}_{2}$ Emission & & & & & & & & & & & & & & & & & & & & & \\
\hline - Geophysical Surveys (GPR/ERT) & & & & & & & & & & & & & & & & & & & & & \\
\hline Plant \& Animal Use Surveys & & & & & & & & & & & & & & & & & & & & & \\
\hline - Floristics (Species Identification and cover) & & & & & & & & & & & & & & & & & & & & & \\
\hline - Canopy Characteristics \& Leaf Area Index & & & & & & & & & & & & & & & & & & & & & \\
\hline - Root Distrubutions & & & & & & & & & & & & & & & & & & & & & \\
\hline - Animal Intrusion & & & & & & & & & & & & & & & & & & & & & \\
\hline Water Balance Measurements & & & & & & & & & & & & & & & & & & & & & \\
\hline - TDR Maintenance/Repair & & & & & & & & & & & & & & & & & & & & & \\
\hline - Water Storage (Vertical Neutron probe) & & & & & & & & & & & & & & & & & & & & & \\
\hline - Horizontal Neutron Probe & & & & & & & & & & & & & & & & & & & & & \\
\hline - Drainage & & & & & & & & & & & & & & & & & & & & & \\
\hline - Runoff & & & & & & & & & & & & & & & & & & & & & \\
\hline Barrier Stability & & & & & & & & & & & & & & & & & & & & & \\
\hline - Elevation Survey & & & & & & & & & & & & & & & & & & & & & \\
\hline - Settlement Gauges & & & & & & & & & & & & & & & & & & & & & \\
\hline - Side Slope Creep gauges & & & & & & & & & & & & & & & & & & & & & \\
\hline Annual Status Report & & & & & & & & & & & & & & & & & & & & & \\
\hline - Draft report to FH & & & & & & & & & & & & & & & & & & & & & \\
\hline - Review and Comments & & & & & & & & & & & & & & & & & & & & & \\
\hline - Final Report to FH & & & & & & & & & & & & & & & & & & & & & \\
\hline
\end{tabular}




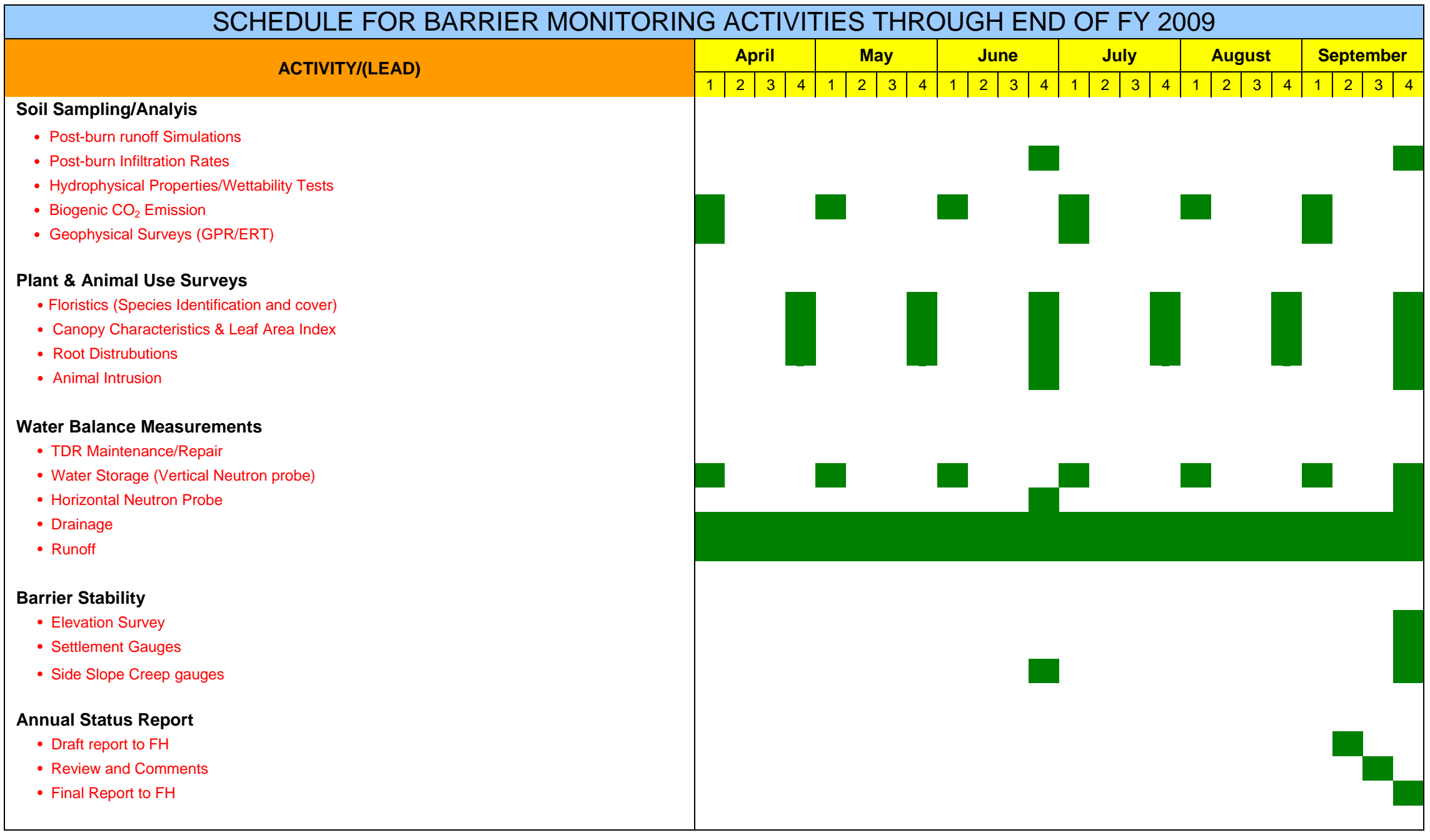




\subsection{Health, Safety and Site Coordination}

Safety and health issues relating to the barrier burn test are addressed in site-specific safety documents (Appendix D) that identify radiological and industrial safety health hazards as well as approved measures to protect against these hazards. Safety documents include specific training requirements that must be met by all site workers and visitors. Job-specific Health and Safety Plans for drilling, instrument installation activities, and sampling activities are also specified in Appendix D. Briefings will be conducted with all site visitors to verify that health and safety issues are understood and that safe practices will be followed during the course of the experiments. All fire effects test participants are required to read and sign the Health and Safety Plan before entering the field site.

\subsubsection{Prescribed Fire Organization}

This burn will involve Hanford Fire Department, FH, PNNL, and WSU personnel on foot and in vehicles. The fire organization will be dictated by the complexity of the burn area. Figure 7.1 shows the organization for the prescribed fire. Bosses of each unit must inform the Ignition Specialist (RXI2) /Firing Boss (FIRB) or Holding Group Leader of fire outside the control lines. Based on that information, the Incident Commander (IC) or Ignition Specialist/Firing Boss will evaluate the need to cease ignition while containing spot fires.

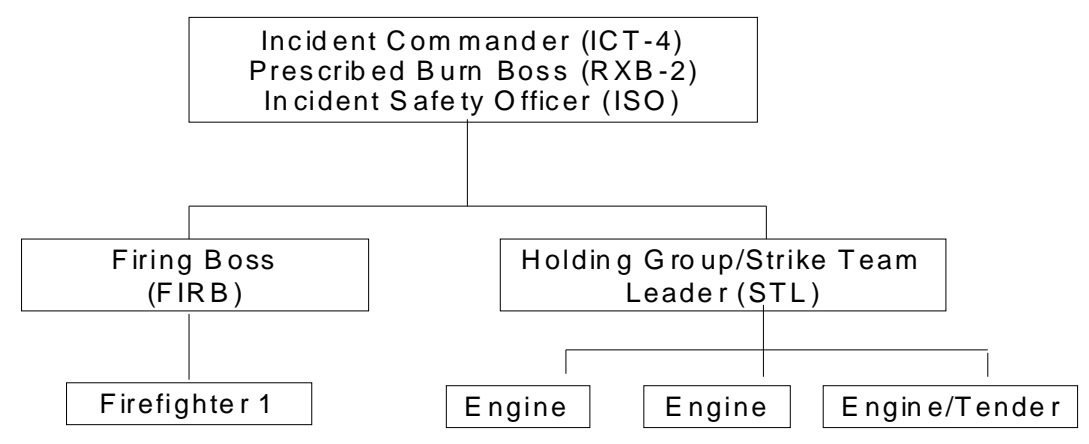

Figure 7.1. Prescribed Fire Organization

An escaped fire requires the immediate change in strategy to suppression with the IC assuming command. Communication between the unit leaders and other personnel will be maintained via HFD radios. Prior to burn, the IC, FIRB, or the RXI2 will inspect all fire line perimeters for integrity, and discuss and review the burn plan with burn crew, including safety considerations and specific assignments. Only HFD qualified personnel will be used to implement ignition and holding actions. HFD units at the barrier and surrounding areas will have foam lines for use as breaks and minimal impact suppression tactics will be enforced in these areas.

The burn plan, escape routes, staff responsibilities, and prescribed burn techniques will be reviewed with fire crew by the Firing Boss. The Firing Boss will check radios, fire shelters, ignition equipment, fire engines, and other fire equipment with the fire crew. The Firing Boss will call the start and "declared out" burn times to HFD Dispatch. The HFD has established a standard communications plan for prescribed burn use (Appendix A). This plan identifies standard crew tactical and command frequencies. 


\subsubsection{Safety Zones}

Safety zones for the burn crew will be the southwest corner of the gravel side slope of the barrier. This area will be reviewed prior to ignition, along with the 10 Fire Orders, 18 Watchout Situations, and Lookouts, Communications, Escape Routes, and Safety Zones (LCES) Principles. HFD Dispatch (509373-2301) will be contacted by radio or cell phone in the event that fire escapes and threatens government facilities or property. Each burn crewmember will wear proper personal protective equipment and follow LCES Principles, which include carrying a personal fire shelter, a hand held radio, and drinking water. Should emergency medical response be necessary, an HFD ambulance will be dispatched. Contact HFD Dispatch, if an ambulance is needed.

This burn test is a prescribed burn within the perimeter of the Hanford Site, as such the Hanford Patrol Operation Center (POC) will be notified prior to and at the completion of the burn. An All Employee message will be issued prior to the first burning activity and signs will be posted each day during burning activities. As a courtesy, HFD will also notify the Benton County Clean Air Authority, Southeast Communications Center, the Hanford POC, Fluor Hanford Emergency Preparedness, FH Communications, and DOE Security and Emergency Services.

\subsubsection{Contingency Plan for Escaped Fire}

All personnel affiliated with this prescribed burn must keep aware of fire activity that threatens the control lines. In addition, all personnel must keep on the lookout for spots across the line. Any and all of these threats should be reported through the chain of command. Fires outside the burn unit must be suppressed immediately. Bosses of each unit must inform the Ignition Specialist/Firing Boss or Holding Group Leader of fire outside the control lines. Based on that information, the IC and/or Ignition Specialist/Firing Boss will evaluate the need to cease ignition while containing spot fires. An escaped fire requires the immediate change in strategy to suppression with the IC assuming command.

In the event that an escape fire occurs (prescription parameters are exceeded and assigned resources cannot control), immediate suppression action will be taken and the prescribed fire ignition will cease until the situation is resolved or mitigated to allow continuation of the burn. Fire crossing control lines does not necessarily constitute an escape fire situation. The IC will determine when an escape fire has occurred. Where the fire crosses control lines, holding forces will attempt to use existing natural or manmade barriers to contain the unlined fire. When an escape fire occurs, the Firing Boss will notify the IC, who will assume command. In the event of an escape fire, notification will be made to the HFD requesting additional resources. In case of an escape fire, notifications will be made to the HFD Fire Chief and to FWS, in accordance with the current FWS Dispatch Plan.

\subsubsection{Barrier Burn Control and Tactics}

The controlled burn of the barrier surface vegetation will be conducted in accordance with the Hanford Fire Department's (HFD) approved “2008 Prescribed Fire Proposal” and burn permit issued by the Benton County Clean Air Agency. The following is a brief synopsis of the barrier burn controls and tactics as discussed in the prescribed fire proposal. 
The HFD will put a scratch line in place bisecting the barrier into a northern and southern half prior to beginning the burn. This scratch line will be emplaced by hand or by using the compressed air foam system on the brush trucks. Prior to burning, a foam line will be laid down along the scratch line to prevent any fire escaping onto the southern half of the barrier. While burning the northern half of the barrier, a brush truck will be close to the burn to ensure an adequate water supply in case of an escape fire. Minimal impact suppression tactics (MIST) will be enforced in the burn area. The fire will be allowed to "burn-out" without the use of water to extinguish the fire. This approach will eliminate potential impacts of fire suppression water on subsequent water balance monitoring conducted to determine the impacts of fire on overall barrier performance. The gravel roadway around the perimeter of the upper soil surface of the barrier also provides a man-made fire break.

Ignition of barrier vegetation will be performed at a rate to meet prescribed burn objectives. The burn area will be monitored post-fire until the threat of spotting has ceased. Drip torches will be used to ignite the burn. Some hand ignition, using fuses, may be used if needed. A hand-held infrared thermometer will be used during the post-fire watch to ensure the fire has "burned-out" and minimize the potential for spotting. Burning will be stopped if the relative humidity drops below 15 percent, sustained wind speeds exceed 18 miles per hour, or the area has a "red flag” warning.

Prior to initiation of the burn, the Incident Commander (IC), Firing Boss (FIRB) and/or the Ignition Specialist (RXI2) will inspect all fire line perimeters for integrity; and review the burn plan, escape routes, staff responsibilities, safety considerations, and prescribed burn techniques with the fire crew. The FIRB will check radios, fire shelters, ignition equipment, fire engines and other fire equipment with the fire crew. The FIRB will call the "start" and "declared out” burn times to HFD Dispatch.

Safety zones for the fire crew and on-site observers will be established by the HFD. These safety zones will be reviewed prior to ignition along with applicable fire orders; watch-out situations; and lookouts, communications, escape routes, and safety zones (LCES) principles. Each member of the fire crew will wear proper personal protective equipment and follow LCES principles. Only National Wildfire Coordinating Group (NWCG) qualified personnel will be used to conduct fire ignition and holding actions. The HFD Dispatch will be contacted (509-373-2301) to send a HFD ambulance to the site if emergency medical response becomes necessary.

Spot weather forecast information will be solicited from the National Weather Service in Pendleton, Oregon. If available, spot weather forecast information will be obtained at least one-hour before initiating the burn. The Hanford Meteorological Services weather station will be used to monitor conditions during the burn. On-site observations will be collected as well.

The HFD Dispatch will be contacted in the event that fire escapes and threatens government facilities or property. In the event that an escape fire occurs (prescribed burn parameters are exceeded and assigned resources cannot control the fire), immediate suppression action will be taken and the prescribed fire ignition will cease until the situation is resolved or mitigated to allow continuation of the burn. Fire crossing control lines does not necessarily constitute an escape fire situation. The IC will determine when an escape fire has occurred. Where the fire crosses control lines, holding forces will attempt to use existing natural or manmade barriers to contain the fire. 
An "All Employee" message will be issued prior to the barrier burn activity and signs will be posted during burning activities. 


\subsection{Waste and Residuals Management}

\subsection{Management Activity A - Solid Waste Management Plan for Soil Analysis}

Scope: This plan covers waste disposition for the waste generated from soil sampling and analysis for the fire effects study at the barrier.

Anticipated Waste Streams: Based on the proposed tests, anticipated waste streams will be limited to non-regulated, nonhazardous solid wastes. The site is posted as a non-radiological area, and therefore, none of the waste is expected to be classified as radiological waste. Materials remaining after characterization and analysis will be reintegrated with the original samples for disposal.

Waste Management: The waste stream described above will be disposed of to a normal trash receptacle. The management of any other unanticipated solid waste will be in accordance with PNNL internal waste management procedures.

Contingency Plan: In the event of a spill or accidental release of a material to the environment, the procedure for spill response (http://sbms.pnl.gov/standard/0e/0e00t010.htm) will be in effect.

If a spill occurs, call 375-2400.

\subsection{Management Activity A - Solid Waste Management Plan for Plant Samples}

Scope: This plan covers waste disposition for the waste generated from plant biomass sampling and analysis for the fire effects study at the barrier.

Anticipated Waste Streams: Based on the proposed tests, anticipated waste streams will be limited to non-regulated, nonhazardous solid wastes. The site is posted as a non-radiological area, and therefore, none of the waste is expected to be classified as radiological waste. Plant biomass samples remaining after characterization and analysis will be reintegrated with the original samples for disposal.

Waste Management: The waste stream described above will be disposed of to a normal trash receptacle. The management of any other unanticipated solid waste will be in accordance with PNNL internal waste-management procedures.

Contingency Plan: In the event of a spill or accidental release of a material to the environment, the procedure for spill response (http://sbms.pnl.gov/standard/0e/0e00t010.htm) will be in effect.

If a spill occurs, call 375-2400. 



\subsection{Quality Assurance}

All work conducted by PNNL and its subcontractors shall be performed in accordance with appropriate standards of quality, reliability, environmental compliance, and safety based on client requirements, cost and program objectives, and potential consequences of malfunction, or error. To provide the client with quality products and services, PNNL has established and implemented a formal Quality Assurance (QA) Program. These management controls are documented in the PNNL StandardsBased Management System (SBMS). Staff at PNNL, FH, and DOE-RL can access the SBMS menu. PNNL staff can go to PNNL's internal home page at http://labweb.pnl.gov/ and select SBMS. Off-site users can access SBMS by going to http://sbms.pnl.gov/. This QA Program also complies with the format requirements of QAMS-005/80, Interim Guidelines and Specifications for Preparing Quality Assurance Project Plans. If other quality-related activities are later performed, the appropriate SBMS requirements and procedures shall be applied, unless specifically excluded. 



\subsection{References}

Albini FA. 1976. Estimating wildfire behavior and effects. U.S. Forest Service General Technical Report INT-30. Intermountain Forest and Range Experiment Station. Ogden, Utah.

Armour CD, SC Bunting, and LF Neuenschwander. 1984. "Fire Intensity Effects on the Understory in Ponderosa Pine Forests.” Journal of Range Management 37:44-49.

American Society of Testing and Materials (ASTM). 2000. Standard Practice for Classification of Soils for Engineering Purposes (Unified Soil Classification System). ASTM D2487-00. Philadelphia, Pennsylvania.

American Society of Testing and Materials (ASTM). 2007. Standard Test Method for Particle-Size Analysis of Soils. ASTM D422-63. Philadelphia, Pennsylvania.

Bauhus J, PK Khanna, and RJ Raison. 1993. The effect of fire on carbon and nitrogen mineralization and nitrification in an Australian forest soil. Australian Journal of Soil Research 31:621-639.

Beadle NCW. 1940. "Soil Temperatures during Forest Fires and their Effect on the Survival of Vegetation.” Journal of Ecology 28:180-192. DOI:10.2307/2256168.

Borchert MI and DC Odion. 1995. "Fire Intensity and Vegetation Recovery in Chaparral: a Review.” In: Brushfires in California: Ecology and Resource Management. JR Keeley and T Scott, Editors, pp. 91-100. International Association of Wildland Fire. Fairfield, Washington.

Bradstock RA and TD Auld. 1995. "Soil Temperatures during Experimental Bushfires in Relation to Fire Intensity: Consequences for Legume Germination and Fire Management in South-Eastern Australia. Journal of Applied Ecology 32(1):76-84

Brooks ML. 2002. "Peak Fire Temperatures and Effects on Annual Plants in the Mojave Desert.” Ecological Applications 12:1088-1102.

Brunauer S, PH Emmett, and E Teller. 1938. “Adsorption of Gases in Multimolecular Layers.” Journal of the American Chemical Society 60:309-319.

Butnor JR, JA Doolittle, L Kress, S Cohen, and KH Johnsen. 2001. "Use of Ground-Penetrating Radar to Study Tree Roots in the Southeastern United States.” Tree Physiology 21:1269-1278.

Byram GM. 1959. “Combustion of forest fuels.” In: Forest Fire Control and Use. Kenneth P. Davis, Editor, pp. 61-89. McGraw-Hill Book Company, New York.

Covington WW, LF DeBano, TG Huntsberger. 1991. "Soil Nitrogen Changes Associated with Slash Pile Burning in Pinyonjuniper Woodlands.” Forest Science 37:347-355.

DeBano LF, SM Savage, and DA Hamilton. 1976. The transfer of heat and hydrophobic substances during burning. Soil Sci. Soc. Am. J. 40, 779-782. 
DeBano LF. 1981. Water Repellent Soils: A State of the Art, General Technical Report. PSW-46, Pacific Southwest Forest and Range Exp. Sta., U.S. Department of Agriculture Forest Service. Berkeley, California.

Dekker LW. 1998. "Effect of Drying Temperature on the Severity of Soil Water Repellency.” Soil Science 163:780-796.

Dekker LW and CJ Ritsema. 2004. "How Water Moves in a Water-Repellent Sandy Soil: I. Potential and Actual Water Repellency.” Water Resources Research 30:2507-2517.

De Marco A, AE Gentile, C Arena, and DeS AV Virzo. 2005. "Organic Matter, Nutrient Content and Biological Activity in Burned and Unburned Soils of a Mediterranean Maquis Area of Southern Italy.” International Journal of Wildland Fire 14:365-377.

Ferreira AJD, COA Coelho, AK Boulet, and FP Lopes. 2005. “Temporal Patterns of Solute Loss Following Wildfires in Central Portugal.” International Journal of Wildfire 14:401-412.

Fierro A, FA Rutigliano, A De Marco, S Castaldi, and AV De Santo. 2007. "Post-Fire Stimulation of Soil Biogenic Emission of $\mathrm{CO}_{2}$ in a Sandy Soil of a Mediterranean Shrubland.” International Journal of Wildland Fire 16(5):573-583.

Fire Effects Information Service (FEIS). 2008. Fire Effects Information. U.S. Department of Agriculture Forest Service. Accessed September, 2008, at http://www.fs.fed.us/database/feis/plants/index.html.

Folk RL. 1980. Petrology of Sedimentary Rocks. Hemphill Publishing Company. Austin, Texas.

Gee GW and JW Bauder. 1986. “Particle-Size Analysis.” Chapter 15 in: Methods of Soil Analysis, Part 1: Physical and Mineralogical Methods. A Klute, Editor, pp. 383-409. American Society of Agronomy, Soil Science Society of America, Inc., Madison, Wisconsin.

Giovannini G, S Lucchesi, and M Giachetti. 1988. "Effect of Heating on Some Physical and Chemical Parameters Related to Soil Aggregation and Erodability.” Soil Science 146:255-262.

Goforth BR, RC Graham, KR Hubbert, CW Zanner, and RA Minnich. 2005. "Spatial Distribution and Properties of Ash and Thermally Altered Soils after High-Severity Forest Fire, Southern California.” International Journal of Wildland Fire 14:343-354.

Graham RT, AE Harvey, MF Jurgensen, TB Jain, JR Tonn, and DS Page-Dumroese. 1994. Managing Coarse Woody Debris in Forests of the Rocky Mountains. U.S. Department of Agriculture Forest Research Paper INT-RP-477. Intermountain Research Station. Ogden, Utah.

Hruska J, J Cemak, and S Sustek. 1999. “Mapping Tree Root Systems with Ground-Penetrating Radar.” Tree Physiology 19:125-130.

Hubbert KR and V Oriol. 2005. "Temporal Fluctuations in Soil Water Repellency Following Wildfire in Chaparral Steeplands, Southern California.” International Journal of Wildland Fire. 14:439-447. 
Jenkinson DS and DS Powlson. 1976. "Effects of Biocidal Treatments on Metabolism in Soil .5. Method for Measuring Soil Biomass.” Soil Biology \& Biochemistry 8:209-213.

Larsen KW, IT Adams, and DL Haughland. 2007. "Small Mammal Communities in a Pyrogenic Habitat Mosaic.” International Journal of Wildland Fire 16(6):728-740

Larsen IJ, HL MacDonald, E Brown, D Rough, MJ Welsh, JH Pietraszek, Z Libohova, and K Schaffrath. 2007. Causes of Post-Fire Runoff and Erosion: the Roles of Soil Water Repellency, Surface Cover, and Soil Sealing.

Ligotke MW. 1994. “Control of Eolian Soil Erosion from Waste Site Surface Barriers.” In: In-Situ Remediation: Scientific Basis for Current and Future Technologies : Thirty-Third Hanford Symposium on Health and the Environment, Richland, Washington , 7-11 Nov 1994; GW Gee and NR Wing, Editors, pp. 549-559, Battelle Press, Richland, Washington.

Luce CH and TW Cundy. 1994. "Parameter Identification for a Runoff Model for Forest Roads.” Water Resources Research 3094):1057-1069.

Marion GM, JM Moreno, and WC Oechel. 1991. "Fire Severity, Ash Deposition, and Clipping Effects on Soil Nutrients in Chaparral.” Soil Science Society of America Journal 55:235-240.

Neary DG, CC Klopatek, LF DeBano, and PF Ffolliott. 1999. "Fire Effects on Belowground Sustainability: A Review and Synthesis.” Forest Ecology and Management 122:51-71.

Nelson DW and LE Sommers. 1982. “Total Carbon, Organic Carbon, and Organic Matter.” p. 539-579. In: Methods of Soil Analysis. Part 2. Chemical and Microbiological Properties. 2nd ed. Agronomy Monogram 9. AL Page, Editor, American Society of Agronomy and Soil Science Society of America. Madison, Wisconsin.

Powers RF, DH Alban, RE Miller, AE Tiarks, CG Wells, PE Avers, RG Cline, RO Fitzgerald, and NS Loftus. 1990. "Sustaining Site Productivity in North American Forests: Problems and Prospects." pp. 49-79. In: Sustained Productivity of Forest Soils, SA Gessel, DS Lacate, GF Weetman, and RF Powers, Editors, Proceedings of the 7th North American Forest Soils Conference, Vancouver, British Columbia, July 1998, University of British Columbia, Vancouver, British Columbia.

Reynolds WD. 1993. “Chapter 59, Unsaturated Hydraulic Conductivity: Field Measurement.” Pages 633-644. In MR Carter, Editor, Soil Sampling and Methods of Analysis. Canadian Society of Soil Science: Lewis Publishers. Boca Raton, FL.

Reynolds WD and DE Elrick. 1985. In Situ Measurement of Field-Saturated Hydraulic Conductivity, Sorptivity and the $\alpha$-Parameter Using the Guelph Permeameter. Soil Science 140(4):292-302.

Rinne JN. 1996. Short-Term Effects of Wildfire on Fishes and Aquatic Macroinvertebrates in the Southwestern United States. North American Journal of Fisheries. Management. 16:653-658.

Robichaud PR. 1996. Spatially-Varied Erosion Potential from Harvested Hillslopes after Prescribed Fire in the Interior Northwest. Ph.D. Dissertation. University of Idaho, Moscow, Idaho. 
Robichaud PR. 2000. Fire Effects on Infiltration Rates after Prescribed Fire in Northern Rocky Mountain Forests, USA. Journal of Hydrology 231(232):220-229.

Robichaud PR and SM Miller. 2000. "Spatial Simulations to Describe Duff Consumption of Prescribed Fire. International Journal of Wildland Fire 9:17-143.

Rolston DE. 1994. “Measuring and Modeling Gaseous Losses of Nitrogen.” p. 1325. In: 25th Congress of the International Association of Hydrogeologists. Adelaide, Australia.

Stokes A, T Fourcaud, J Hruska, J Cermak, N Nadyezhdin and L Praus. 2002. “An Evaluation of Different Methods to Investigate Root System Architecture of Urban Trees In Situ: I. Ground-Penetrating Radar.” Journal of Arboriculture 28(1):1-9

Úbeda X, M Lorca, LR Outeiro, S Bernia, and M Castellnou. 2005. "Effects of Prescribed Fire on Soil Quality in Mediterranean Grassland (Prades Mountains, North-East Spain).” International Journal of Wildland Fire 14(4):379-384

U.S. Department of Energy-Richland Operations office (DOE-RL). 1999. Prototype Barrier Treatability Test Report. DOE/RL-99-11, Rev. 0. U.S. DOE/RL. Richland, Washington.

U.S. Department of Energy (DOE). 2005a. Proposed Plan for the 200-UW-1 Operable Unit.DOE/RL2003-24. DOE. Washington, D.C.

U.S. Department of Energy (DOE). 2005b. Focused Feasibility Study for the 200-UW-1 Operable Unit. DOE/RL-2003-23, Rev. 0. DOE. Washington, D.C.

Doerr SH and A Cerdà. 2005. "Fire Effects on Soil System Functioning: New Insights and Future Challenges.” International Journal of Wildland Fire 14(4) 339-342.

U.S. Environmental Protection Agency (EPA). 1994. "Determination of Inorganic Anions by Ion Chromatography, Method 9056” in Test Methods for Evaluating Solid Waste, Physical/Chemical Methods, SW-846. Accessed September, 2008, at http://www.epa.gov/epaoswer/hazwaste/test/sw846.htm.

U.S. Environmental Protection Agency (EPA). 1996. "Inductively Coupled Plasma-Atomic Emission Spectrometry, Method 6010B” in Test Methods for Evaluating Solid Waste, Physical/Chemical Methods, SW-846. Accessed September, 2008, at http://www.epa.gov/epaoswer/hazwaste/test/sw846.htm.

Upchurch DR and JT Ritchie. 1983. "Root Observations Using a Video Recording System in MiniRhizotrons.” Agronomy Journal 75:1009-1015.

Upchurch DR and JT Ritchie. 1984. "Battery-Operated Color Video Camera for Root Observations in Mini-Rhizotrons.” Agronomy Journal 76:1015-1017.

Wallis MG and DJ Horne. 1992. “Soil Water Repellency.” Advances in Soil Science 20:91-146.

Ward, AL, GW Gee, and SO Link 1997, Hanford Prototype Barrier Status Report: FY 1997, PNNL-11789. Pacific Northwest National Laboratory. Richland, Washington. 
Ward, AL, JK Linville, JM Keller, and GH Seedahmed. 2005. 200-BP-1 Prototype Hanford Barrier Annual Monitoring Report for Fiscal Year 2004. PNNL-14960. Pacific Northwest National Laboratory. Richland, Washington.

Ward AL, MD White, EF Freeman, and ZF Zhang. 2005a. STOMP Sparse Vegetation Evapotranspiration Model for the Water-Air-Energy Operational Mode. PNNL-15465. Pacific Northwest National Laboratory. Richland, Washington.

Ward AL, ME Conrad, WD Daily, JB Fink, VL Freedman, GW Gee, GM Hoversten, JM Keller, EL Majer, CJ Murray, MD White, SB Yabusaki, and ZF Zhang. 2006. Vadose Zone Transport Field Study: Summary Report. PNNL-15443. Pacific Northwest National Laboratory. Richland, Washington.

Ward AL, SO Link, CE Strickland, KE Draper, and RE Clayton. 2007. 200-BP-1 Prototype Hanford Barrier Annual Monitoring Report for Fiscal Years 2005 Through 2007. PNNL-17176. Pacific Northwest National Laboratory. Richland, Washington.

Wentworth CK. 1922. “A Scale of Grade and Class Terms for Clastic Sediments.” Journal of Geology 30:377-392.

White MD and AL Ward. 2005. "Numerical Simulation of Surface Barriers for Shrub-Steppe Ecoregions.” Hydrology Days 25:224-236.

Wielopolski L, G Hendrey, J Daniels, and M McGuigan. 2000. "Imaging Tree Root Systems In Situ.” Proceedings of the 8th International Conference on Ground-Penetrating Radar, DA Noon, GF Stickley, and D Longstaff, Editors, May 23-26, Gold Coast, Queensland, Australia. Proceedings of SPIE-the International Society of Optical Engineering. Bellingham, Washington. 4084:642-646

Winfield KA and JR Nimmo. 2002. "Controlled Liquid Volume. In: Methods of Soil Analysis Part 4. Physical Methods, JH Dane and GC Topp, Editors, Soil Science Society of America Book Series, No. 5. Soil Science Society of America Journal. Madison, Wisconsin. 

Appendix A

\section{Prescribed Burn Permit}





\section{Appendix A}

\section{Prescribed Burn Permit}

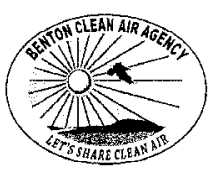

\section{BENTON \\ CLEAN AIR AGENCY \\ $526 \mathrm{~S}$. Clodfelter Rd}

Kennewick, WA 99336

Phone: (509) 783-1304 -- FAX: (509) 783-6562

E-mail: email@bcaa.net internet: $h$ ttp://bcaa.net

\begin{tabular}{l|l} 
IN THE MATTER OF THE & SPECIAL BURNING PERMIT \\
COMPLIANCE BY Fluor Hanford, Inc and Hanford & No. 20080007 \\
Fire Department with Chapter 70.94 RCW and the & Fire Prevention \\
Rules and Regulations of the Benton Clean Air & Other Outdoor Burning \\
Agency &
\end{tabular}

To: Flour Hanford, Inc.

Attn: Chief Bob Kirk

P.O. Box 550

Richland, WA 99352

In accordance with the provisions of Washington Administrative Code (WAC) 173-425 your request to conduct open burning during the period from June 6,2008 to June 5 , 2009 , is approved. This permit is valid only for the amount, material, conditions, and time period specified on the Request for Special Burning Permit application. Failure to comply with the terms of this permit is grounds for a violation to be issued and penalties assessed.

Approved open burning activities will be conducted in accordance with the provisions of WAC 173-425 and all provisions set forth in this conditional permit, as follows:

1. Other than the material requested and permitted by this permit, you may not burn any prohibited material as indicated in WAC 173-425-040(1), which reads, "(1) Except as provided in WAC 173-425-020(2), the following materials shall not be burned in any outdoor fire: Garbage, dead animals, asphalt, petroleum products, paints, rubber products, plastics, paper (other than what is necessary to start a fire), cardboard, treated wood, construction debris, metal or any substance (other than natural vegetation) which when burned releases toxic emissions, dense smoke, or odors."

2. Requirements and conditions of local fire protection agencies must be met.

3. This permit is good only for the time period and site for which it was issued. You are not allowed to burn during additional time periods or at alternate sites with this permit.

4. No fires are to be within fifty (50) feet of structures.

5. A person representing your organization must attend the fire at all times and you must have the means to extinguish the fire completely if and when necessary.

S:TTechSvcsiPermittinglBurn Permits \Special BurniCurrentlCY2008120080007 Fluor Hanford \& Hanford Fire.doc 
6. The Clean Air Agency will be notified prior to commencing burning. Please notify the Inspector at (509) 783-1304 to inform of time and areas burning will be conducted. If after hours, leave a message on the answering machine.

7. Burning will be conducted to promote good combustion practices with a minimum of soil mixed with the material to be burned.

8. You may not burn if smoke unreasonably interferes with other's use and enjoyment of property. Burn only when wind takes smoke away from roads, homes, population centers, or other public areas to the greatest extent possible.

9. The holder of this permit assumes all responsibility for his/her acts.

\section{Additional Special Requirements:}

1. The fee for this burn of 500 acres is $\$ 4,250.00$. The application fee is $\$ 57.00$. Please remit $\$ 4,307.00$ to this Agency within thirty (30) days of issuance of permit.

2. Per item 6 above, the person responsible for burning must call BCAA office staff at 783-1304, to inform the inspector of times and areas where the burning will be conducted.

3. Please take appropriate precautions to prevent the burning of prohibited materials, such as painted wood and other garbage, which may be mixed in with the vegetation you intend to burn.

4. In the interest of safety, and air pollution control, limit the amount of material burned at one time to a manageable minimum.

5. Fires may be ignited by a propane torch. No fuels may be burned.

This "Special Burning Permit" and the conditions contained herein relate only to air quality and compliance with the provisions of the Washington State Clean Air Act (RCW 70.94), the Washington Administrative Code (WAC 173-425) and the Benton Clean Air Agency Regulation 1. Compliance with the terms and conditions of this permit does not relieve the permit holder from responsibility for damages to person and/or property caused by any fire conducted in accordance with this permit. By signing this permit the Benton Clean Air Agency assumes no responsibility for the acts of the person(s) acting under this permit.

DATED at Kennewick, Washington, on May 28, 2008.

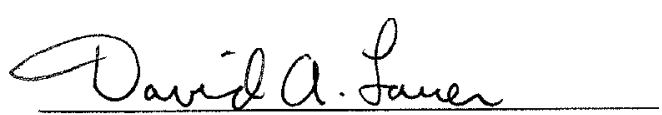

David Lauer Control Officer

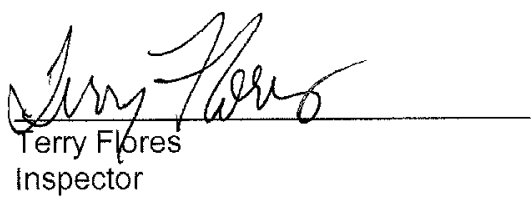

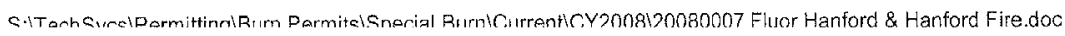


Please remit bottom portion of this page with payment if applicable

Name or name of organization to who permit was issued Fluor tranford the.

Date permit was issued

Fee due

Signature and date

S:ITechSvcs PermittinglBurn PermitsiSpecial BurniCurrentiCY2008120080007 Fluor Hanford \& Hanford Fire.doc 


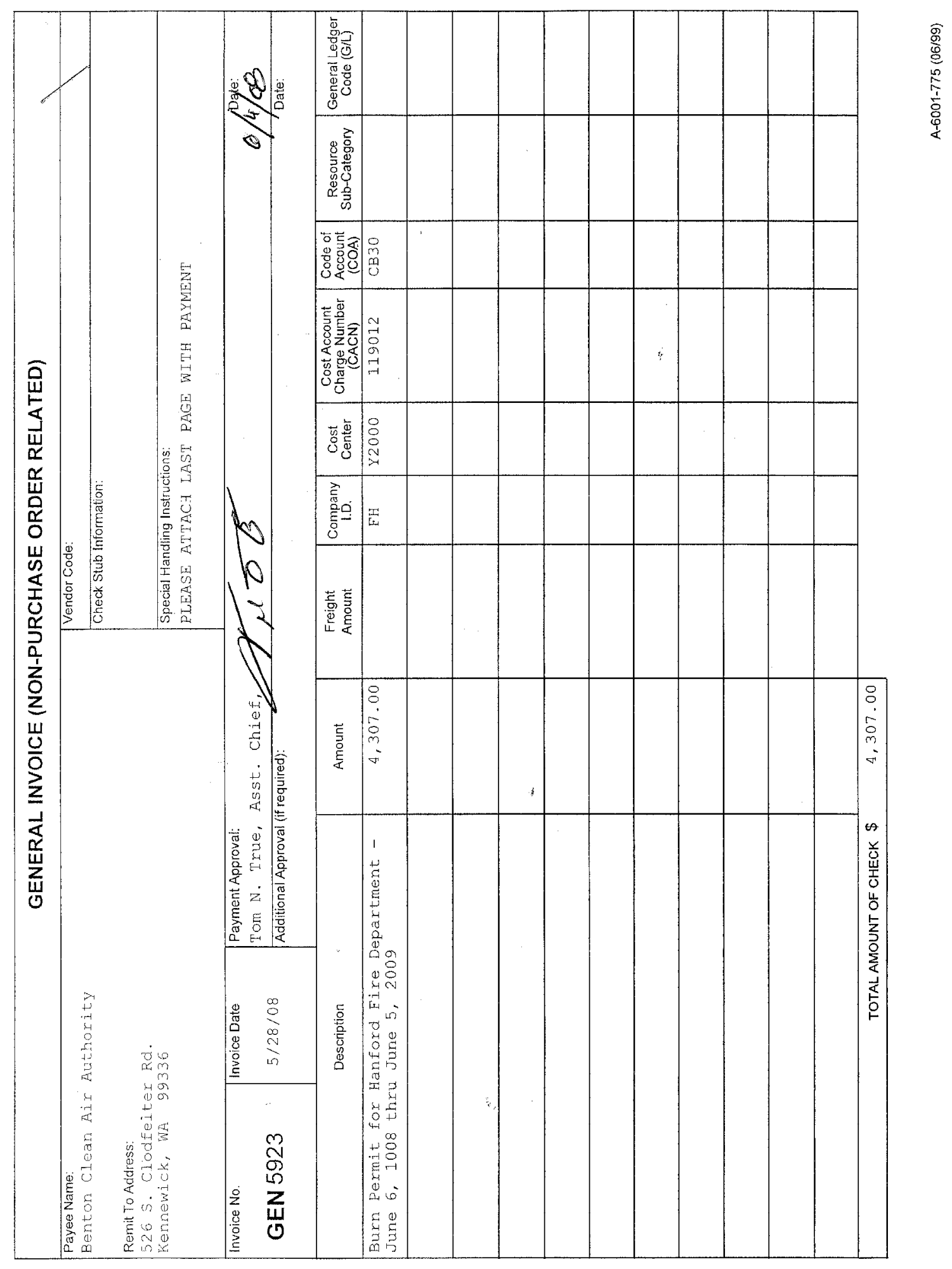


Appendix B

\section{Biological Resource Review}





\section{Appendix B}

\section{Biological Resource Review}

$09 / 09 / 2008 \quad 14: 43$

5093731153

\begin{tabular}{|c|c|}
\hline Post-it' Fax Note & Date $9 / 9108$ pages 3 \\
\hline To ANDY W/OAORD & From Mike SAckschtensky \\
\hline$\frac{A N}{C_{0} / \text { Dept. }}$ & Co. \\
\hline Phone t: & Phone" \\
\hline Fax:372-6089 & $\overline{F a x} \bar{\pi}$ \\
\hline
\end{tabular}

NATURAL RESOURCES DV

PAGE $01 / 03$

September 8, 2008

Dr. Andy Ward

Pacific Northwest National Laboratory

P.O. Box 999, MSIN K9-33

Richland, WA 99352

Dear Dr. Ward:

BIOLOGICAL REVIEW OF THE PROTOTYPE BARRIER PRESCRIBED BURN PROJECT, 200 EAST AREA, ECR \#2008-200-024.

\section{Project Description:}

- Conduct a simulated wildfire (prescribed burn across the northern half of the 200BP-1 Prototype Hanford Barrier in the 200 East Area). The intent is that all surface vegetation will be removed by the prescribed burn.

\section{Survey Objectives:}

- Determine the occurrence in the project area of plant and animal species protected under the Endangered Species Act (ESA), candidates for such protection, and species listed as threatened, endangered, candidate, sensitive, or monitor by the state of Washington, and species protected under the Migratory Bird Treaty Act (MBTA).

- Evaluate and quantify the potential impacts of disturbance on priority habitats and protected plant and animal species identified in the survey.

\section{Survey Methods:}

- Pedestrian and visual reconnaissance of the proposed project site was performed by J. L. Downs on August 28, 2008. The percent cover of dominant vegetation was visually estimated.

- Priority habitats and species of concern are documented in: Washington Department of Fish and Wildlife (2008a, 2008b), and Washington State Department of Natural Resources (2008). Lists of animal and plant species 
Dr. Andy Ward

2008-200-024

Page 2 of 3

considered Endangered, Threatened, Proposed, or Candidate by the U.S. Fish and Wildlife Service are maintained at 50 CFR 17.11 and 50 CFR 17.12; the list of birds protected under the MBTA is maintained at 50 CFR 10.13 .

\section{Survey Results:}

- The vegetation on the surface of the barrier is limited primarily to big sagebrush (Artemisia tridentata) with sparse cover of bluebunch wheatgrass

(Pseudoroegnaria spicata) at the perimeter of the prototype barrier. Sideslopes of the barrier are vegetated with these two species and are dominated by rubber rabbitbrush (Ericameria nauseosa) and bluebunch wheatgrass along with scattered Sandberg's bluegrass (Poa secunda).

- No migratory bird species were observed nesting in the vicinity of the proposed site.

- No mammals or herpetofauna were observed on the site; however, small mammal burrows and droppings of mountain cottontail (Sylvilagus nuttalli) were observed. Much of the grass had been clipped by herbivores.

\section{Considerations and Recommendations:}

- No plant or animal species protected under the ESA, candidates for such protection, or species listed by the Washington state government as threatened or endangered were observed in the vicinity of the proposed site.

- If any nesting birds (if not a nest, a pair of birds of the same species or a single bird that will not leave the area when disturbed) are encountered, or bird defensive behaviors (flying at workers, refusal to leave the area, strident vocalizations) are observed during Project activities, please contact M.R. Sackschewsky at 371-7187 for further consultation.

- Ground-disturbing activities, such as those associated with the use of heavy equipment to blade and spread gravel, present the potential for transport, spread and increase of noxious weedy species. When feasible, off-road travel should be minimized, and wheels and undercarriages of vehicles and heavy equipment should be washed to minimize transport of weed seeds.

- Assuming compliance with the above recommendation, no adverse impacts to protected species, priority habitats, or other biological resources of concern are expected to result from the proposed action.

- This Ecological Compliance Review is valid until 15 April 2009. 
Dr. Andy Ward 2008-200-024

Page 3 of 3

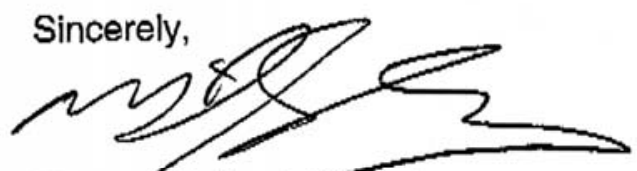

Michael R. Saekschewsky

Compliance Assessment Manager

Ecological Monitoring and Compliance Project

LB:mrs

\section{REFERENCES}

Washington Department of Fish and Wildlife. 2008a. Species of Concern in Washington State. http://wdfw.wa.gov/w/m/diversty/soc/soc.htm

Washington Department of Fish and Wildlife. 2008b. Priority Habitats and Species. http://wdfw.wa.gov/hab/phshabs.htm

Washington State Department of Natural Resources. 2008. Washington Natural Heritage Program Plant Ranks.

http://www1.dnr.wa.gov/nhp/refdesk/lists/plantrnk.html 

Appendix C

\section{Cultural Resource Review}





\section{Appendix C}

\section{Cultural Resource Review}

Ward, Anderson L

$\begin{array}{ll}\text { From: } & \text { Prendergast-Kennedy, Ellen L } \\ \text { Sent: } & \text { Monday, September 15, 2008 11:22 AM } \\ \text { To: } & \text { Ward, Anderson L } \\ \text { Subject: } & \text { Cultural Resources Review Complete: 200-BP-1 Barrier Monitoring - Assessing Fire Behavior } \\ & \text { and Impacts on an Engineered Surface Barrier Ecosystem (NPCE\#2008-200-024) }\end{array}$

Mr. Ward:

Thank you for contacting our office regarding your project. The project area is located in the 200 East Area, Hanford Site. The project activity is to document and quantify the fire behavior and impacts on the 200-BP-1 engineered barrier ecosystem located in the 200 East Area of the Hanford Site. The specific objective is to quantify the effect of burning and the resulting post-fire environmental conditions on alterations in soil physical (e.g. aggregate stability, pore size, distribution, water repellency and runoff response), geochemical (e.g. mineralogy, $\mathrm{pH}$, nutrient availability, $\mathrm{C}: \mathrm{N}$ ratios) and biological (e.g. biomass productivity, microbial composition, carbon sequestration, plant and animal habitat) properties. A simulated wildfire will be initiated, controlled and monitored on the north half of the 200-BP-1 prototype Hanford barrier in collaboration with the Hanford Fire Department during the fall of FY 2008. The north half of the barrier will be divided into $6 \mathrm{~m}^{\prime} 6 \mathrm{~m}$ plots to each of which a fuel load of $2 \mathrm{~kg} \mathrm{~m}^{-2}$ or $4 \mathrm{~kg} \mathrm{~m}^{-2}$ will be assigned. Monitoring of the fire and its effects will be based on the integration of point measurements of hydrologic and biotic variables with intermediate scale non-invasive geophysical measurements and airborne techniques. Near-surface $(0-10 \mathrm{~cm})$ soil samples will be collected and used to determine the effects of fire on hydrophysical, geochemical, mineralogical, and biological properties. Plant information, including species, shrub height, greatest canopy diameter, and the diameter at the center of the plant perpendicular to the greatest diameter will be measured on a minimum of 25 shrubs and general assessments of shrub survival and recruitment will be made. The composition, demography, and variation of small mammals populations and insects on the north half of the barrier will be examined preand post burn and the barrier surface will be examined for evidence of use and intrusion (burrowing) by insects and small mammals. Results will be used to draw inferences about fire behavior under different fuel loadings and environmental conditions, the consequences of differing fire frequencies, fire intensities, and fire severities on engineered barriers in relation to changes in habitat and hydrophysical properties. The project is a $1-\mathrm{yr}$ project running from August 2008 through September 2009. The depth of excavation will be $0-30 \mathrm{~cm}$.

Per 36 CFR Part 800, Subpart B, 800.3.a, the DOE-RL Cultural Resources Program has determined that this project is not the type of undertaking with potential to cause effects to historic properties and no further actions are required. The finding is based on the following:

- The 2006 aerial photographs indicate extensive disturbance in this area.

- There are no known cultural resources in the area.

All workers should be directed to watch for cultural materials (e.g. bones, artifacts) during all work activities. If any are encountered, work in the vicinity of the discovery must stop until an HCRP archaeologist has been notified, assessed the significance of the find, and, if necessary arranged for mitigation of the impacts to the find. Please contact Doug McFarland or Ellen Prendergast-Kennedy, HCRP, if any changes to project location or scope are anticipated.

For tracking purposes, NPCE\# 2008-200-024 has been assigned to your request.

Again, thank you for contacting us regarding your project. 
Chantry Dage

Technical Intern 1

Environmental Sustainability Division/Environmental Characterization and Risk Assessment

Pacific Northwest National Laboratory

902 Battelle Boulevard

P.O. Box 999, MSIN K6-75

Richland, WA 99352 USA

Tel: 509-371-7089

Fax: 509-371-7083

chantry.dage@pnl.gov

www.pnl.gov 


\section{Appendix D}

Site Access and Conduct Requirements for the Barrier 



\section{Appendix D}

\section{Site Access and Conduct Requirements for the Barrier}

\section{D.1 Application and Scope}

This plan covers all activities at the Prototype Barrier performed by the Pacific Northwest National Laboratories (PNNL) as part of the Barrier Monitoring Project, including the simulated wildfire and associated monitoring. These activities are being conducted in collaboration with Washington State University, Tri-Cities (WSU-TC). This plan serves as the site health and safety briefing and provides general requirements for staff, contractors involved in performing testing and monitoring activities as well as visitors to the prototype barrier. Access for workers supporting the Monitoring Project depends on reading, signing, and agreeing to comply with the information described herein.

It is the express policy of Pacific Northwest National Laboratories (PNNL) that all work by its employees or subcontractors is conducted in a safe and conscientious manner. For this project all personnel and visitors at the barrier shall adhere to this and other applicable Health and Safety Plans or Job Safety Analysis elements (e.g., those pertaining to surface or subsurface contamination areas, travel in remote areas, and/or field work after regular business hours) and follow the directions of the Project Manager or Field Team Leader. This Plan sets forth the minimum acceptable standards as required by federal or state regulations.

Visitors, escorted by an authorized worker and not performing work, need not review and sign this document unless the nature of the visit is such that the visitor might encounter site-specific safety issues. The master copy of this document shall be maintained in an accessible location in the project manager's office. A copy shall be maintained at the barrier test site. The signature sheets shall be maintained by the project manager. Subsequent versions of this document may be prepared if access or conduct requirements change. Notification of subsequent versions will be made to project staff and authorized workers. Each new version of the document will require the review and signature of each worker prior to that person's continued work at the site.

\section{D.2 Background}

The barrier was constructed in 1994 to evaluate surface barrier constructability, construction costs, and physical and hydrologic performance at the field scale. The barrier has been routinely monitored since November 1994, first as part of a Comprehensive Environmental Response, Compensation, and Liability Act of 1981 (CERCLA) treatability test (Nov. 1994 - Sep. 1998) and later as part of a long-term performance study. Since September 1998, monitoring has focused on a limited set of water balance, stability, vegetation dynamics, and indicators of vegetation and animal intrusion. Monitoring activities have included the following:

- Water balance monitoring including precipitation, soil moisture, and drainage measurements

- Barrier stability monitoring including asphalt layer settlement, basalt side-slope stability, and surface elevation measurements 
- Vegetation surveys

- Animal intrusion survey

- Simulated wild fire test

The goal of the monitoring project is to obtain information related to the function of an engineered surface barrier during a multi-year period. With the current project, the scope has been expanded to include evaluation of post-fire impacts and the associated long-term ecological and hydrological recovery on the water balance. The barrier was built to the specifications of the current Hanford Barrier design, modified to accommodate testing and monitoring work. Planned work includes activities to monitor the function of the barrier and its response to natural stresses. A one-time simulated wildfire test will be conducted in the fall of 2008 to quantify the effects of burning and the resulting post-fire conditions on alterations in soil physical, geochemical, and biological properties. The goals of the project are important and needed to provide engineering and regulatory agencies with data that confirm the function of the present Hanford Barrier design and that provide design-basis information for the construction of other surface waste site barriers at the Hanford Site. It is the responsibility of each person working at the site to ensure his or her activities do not jeopardize the integrity of the barrier or the goals of the testing and monitoring project.

\section{D.3 Site Description}

The prototype barrier was constructed over and to the north of the B-57 waste crib in the Operable Unit. This Operable Unit is located in the 200 East Area of the Hanford Site in the B-BX-BY complex, northwest of the BY tank farm, north of the B-trenches and southwest of the BY cribs (Figure D.1).

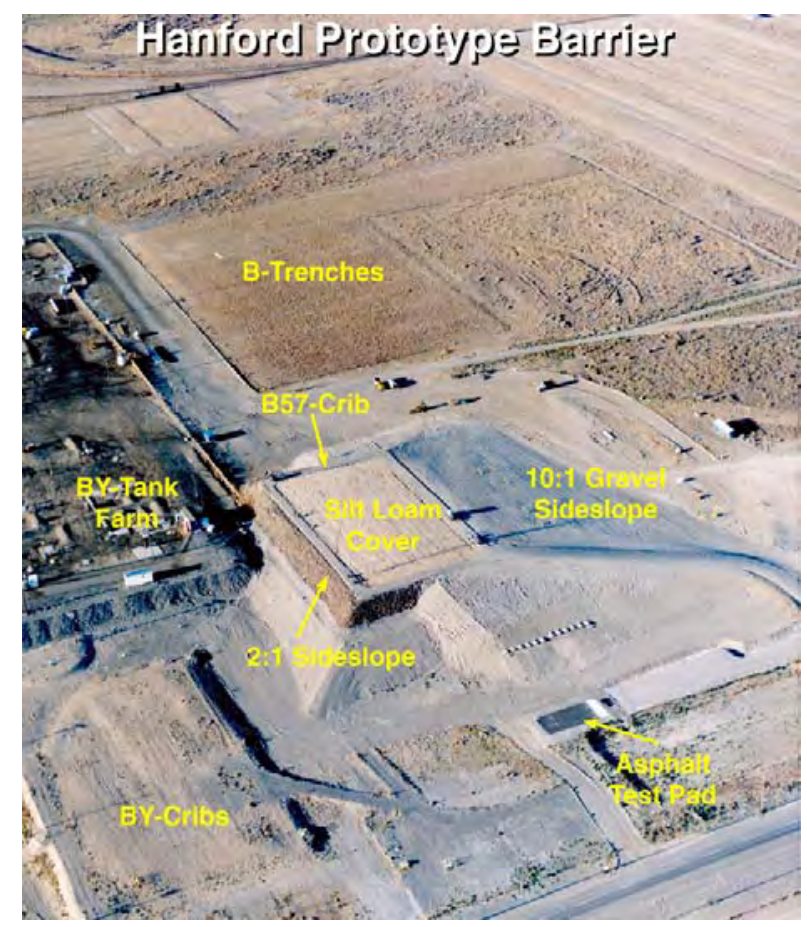

Figure D.1. Aerial View of the Prototype Hanford Barrier and Surrounding Facilities 
Site access and safety requirements refer only to the area within and immediately adjacent to the fenced area surrounding the prototype barrier at the barrier site. Staff should be aware that the BY and BX tank farms are located immediately to the east and southeast of the prototype barrier. Staff should be aware that radiological hazards potentially exist at the site. The prototype barrier is designated as an Underground Radioactive Materials Area (URMA). An URMA is established to indicate the presence of underground items that contain radioactive materials such as the underlying contaminated crib (B-57) at the barrier. The current posting includes a special instruction to consult with the radiological control organization before digging. This general requirement applies for all digging below a 2-m depth within the perimeter of the designated area, since more than $5 \mathrm{~m}$ of clean material was placed on the surface barrier. For any excavation 2 meters in depth at the designated area, the Site Operations Manager (Bill Osborne) shall be contacted at least 72 ahead of the planned activity date. The site is also subject to the transport of radiological materials via wind or biological vectors. Under the current posting, the site is exempt from the general entry and exit requirements provided individual doses do not exceed 100 mrem in a year. Observations of radiological exposure for the past several years indicate that no exposure above background has been detected on workers who have spent any time at the site. Annual surface surveys conducted at the barrier show no evidence of surface contamination.

\section{D.4 Site Access Requirements}

Site access requirements refer only to work in support of the monitoring project within and immediately adjacent to the fenced area surrounding the prototype barrier at the B-57 () Site. Vehicular access is permitted to the north or northwest of the barrier at a designated parking lot, or along the gravel road to the south of the barrier site. Vehicular access beyond the locked chain barrier on the access ramp to the barrier is limited to government vehicles, and requires the approval of the project manager.

Established, routine vehicular access confined to the gravel road around the perimeter of the top of the barrier, such as for irrigation, require approval only once, unless operational conditions change. Access to mow or remove vegetation on the 10:1 side slope to the west of the barrier requires the approval of the project manager annually. To date, mowing of side slope cover has not been needed. Permission for workers to hold the combination or key to locks at the site is the responsibility of the project manager, but may be delegated to the task leaders as needed.

In general, workers should be cognizant of other testing and monitoring activities, and should minimize their impact on the surface or side slopes of the barrier. Foot traffic on the silt top of the barrier should be avoided or minimized as much as possible. Any significant disturbance of the top surface should be repaired or patched to maintain the original surface grade; and surface samples removed that are larger that about $10,000 \mathrm{~cm}^{3}$ should be replaced with $15 \%$ pea gravel/silt admixture (available at a borrow area just northwest of the prototype). Activities such as the repair of precipitation meters, time domain reflectometry sensors, heat dissipation units, thermocouples, etc. are allowed and provided for as part of annual maintenance. Also, staff collecting samples for particle-size and water content analysis are permitted to remove soil samples for appropriate analysis, providing the individual samples are less than 500 grams.

Staff walking on the vegetation should be aware of the potential for surface contamination via biotic pathways biologic activity. For this reason, no animal droppings (feces) are to be removed from the surface without first contacting radiation safety and the project manager. 
For the simulated fire test, personnel should be aware of the additional threat of respiratory distress resulting from smoke inhalation. Burns from falling into open fire during the simulated fire test could be serious especially and with limited access to treatment services at the site. Combustion of plant biomass, especially from plants high in resin content, can release chemicals, as well as particulate matter, into the air that disrupts normal lung function. Personnel should beware of inhaling too much smoke and those that are susceptible are advised to avoid the test site during times when smoke levels are high.

\section{D.5 Potential Site Impacts}

Activities that pose the potential to significantly affect barrier function or testing and monitoring conditions must be authorized and documented by the project manager. Examples of activities that pose such potential include: 1) excavating below grade a hole exceeding $50 \mathrm{~cm}$ deep or $50 \mathrm{~cm}$ wide;

2) operating the irrigation/snow systems in a non- routine manner; 3) driving vehicles on the surfaces of the silt top or side slope sides of the barrier; 4) destroying, obscuring, or relocating survey markers; 5) connecting new systems to power or water services; 6) altering the flow or measurement of drainage water from the barrier; 7) adding water to the surface of the barrier (top or side slopes); and 8) setting devices on the surface or within $15 \mathrm{~m}$ of the wind stations that are greater than $50 \mathrm{~cm}$ tall or $50 \mathrm{~cm}$ wide above grade. This list is not intended to be complete but is included to provide examples of the type of activities that may pose a potentially significant impact. Excavation of any sort outside the boundaries of the fence surrounding the site requires the approval of the Operable Unit Manager.

It is the responsibility of the project manager to determine if an activity poses the risk to cause a significant impact based on the examples provided above and to obtain appropriate approval from the project manager. Prior to work, individuals must resolve any uncertainty about the potential to cause a significant impact with the project manager. Guidelines as outlined in PNL-MA-26 (Radiological Control Procedures) and PNL-MA-50 (Facilities Management Department PNL Operations Manual).

An activity is authorized if approval is obtained from the project manager. It is the responsibility of the project manager to determine the level of documentation needed for each unusual activity (no action, memo-to-file, or other documentation). Activities that pose the potential to affect the testing and monitoring project must be documented in the project manager's site file. Activities that pose the potential to affect the function of the barrier, or that will result in a permanent change to the barrier, require the concurrence of the Operational Unit Manager, and may require 'as-built' drawing changes.

Workers who observe unexpected operations or conditions at the site, also including those which may impact the function or testing and monitoring of the barrier, must report the incident to the project manager.

\section{D.6 Personnel}

\section{D.6.1 Responsible Parties}

PNNL Manager of Fluor Projects:

PNNL Project Manager:

PNNL Principle Staff (PNNL):

Principle Staff (WSU):
M.D. Freshley

A.L. Ward

R.E. Clayton, K.E. Draper, N. Hassan, C.E. Strickland

S.O. Link 


\section{D.6.2 Job Descriptions}

\section{D.6.2.1 Project Manager}

The Project Manager has overall responsibility for the successful outcome of the project and makes the final decision regarding implementation of the Health and Safety Plan. Included in this responsibility is communicating to all persons on the field team any safety or operating requirements pertaining to a particular site, or any changes to the Health and Safety Plan. The Project Manager, or his delegate, will conduct pre-sampling safety meetings to review planned field sampling work. The Project Manager is responsible for notifying PNNL management of any health and safety related issues. The project manager, Andy Ward, will serve as the primary delegate for this work.

\section{D.6.2.2 Field Team Leader}

For each field activity, one or more project staff members will be designated as a Field Team Leader. Designated Field Team Leaders are charged with implementing the Health and Safety Plan in the field. They are responsible for reviewing safety issues, Job Safety Analyses, Radiation Work Permits, and other safety documents that pertain to surveys in a particular area. Field Team Leaders are located onsite during all work and ensure that all personnel on the site work in a safe manner consistent with the requirements of the Health and Safety Plan. Reports of all safety violations or perceived health/safety concerns are made to appropriate management and Laboratory Safety. Deviations from the Health and Safety Plan require prior approval of the Project Manager. Field Team Leader for this work is Ray Clayton.

\section{D.6.2.3 Field Team Members}

All field team members are responsible for understanding and complying with the Health and Safety Plan and all health and safety instructions given by the Field Team Leader or competent authority. All personnel will sign a statement attesting to their having read and understood the Health and Safety Plan. Personnel agree in writing to follow the Plan; all questions must be answered to their satisfaction prior to starting work. Field team members will promptly report all injuries or illness to their direct supervisor who shall inform the Project Manager.

\section{D.7 Communications}

As a general rule, field teams will work together as a group within earshot of each other. Where conditions warrant separating a large team into several pairs that will be out of earshot, cellular phones or two-way radios will be carried by each group. Staff working alone in the field will carry a cell phone with access to 911 Emergency Number; the PNNL Emergency Phone number (375-2400); as well as contact telephone numbers for the Project Manager, Task Manager, and Field Team Leader. 


\section{D.8 Communication/Notification for Work after Normal Business Hours}

The Field Team Leader will establish a point of Project Management Contact (Project Leader, Task Leader or appropriate Project delegate) for all fieldwork to be conducted during non-business hours. Prior to leaving for the field, the Field Team Leader will ensure that the Project Management Contact is informed as to the type of work, the work location, the names of field staff conducting the work, the field team cell phone number and the planned return-to-office time of day. Upon return to the office, the Field Team Leader will contact the Project Management delegate to confirm return to the laboratory from "After Normal Hours" work.

\section{D.9 Site Security}

No work related to the monitoring activities will be performed in or around open excavations or waste sites. Instrumentation and monitoring will be limited to areas that have already undergone source control remediation and are outside fenced areas that are assessable to the general public. The site manager will be notified when field crews are deployed to the general site.

\section{D.10 Work Practices}

General work practices will follow written procedures and job safety analyses established for the Science and Technology Remediation Task, or under the Public Safety Resource Protection Program's Surface Environmental Surveillance Project.

\section{D.11 General Field Practices}

Project personnel will work in a safe manner at all times. This includes, but is not limited to, the following points:

The Field Team Leader will ensure that the Task Leader (or the Task Leader Delegate, Project Manager, Project Manager Delegate) is notified of field work in remote areas and will provide the relevant "in office" lead (Task or Project Leader) with the cell phone number for contact between "office" and "field" staff. The Field Team Leader will also provide to the "in office" Task or Project Leader information including the nature of the fieldwork, the work location, and the expected time of return to the office.

Prior to the start of fieldwork, each worker will be given informal training on how the project will progress. New staff and visitors will be given this training prior to going to a work location. The Project Manager or designate will conduct this training. Topics must include the following:

- key provisions of the plan

- safety hazards anticipated and required control measures

- job safety analyses pertaining to the work

- buddy system explained

- safety equipment operation. 
None of the proposed work is anticipated to lead to solitary conduct of field activities. Nonetheless, all fieldwork will be conducted using the buddy system. The Project Manager's approval is required for solitary conduct of field activities.

At least one person on the field team routinely conducting fieldwork in remote areas will maintain current first aid and CPR training and certification.

All visitors must have prior approval from the Project Manager/ Team Leader before participating on a field team. Visitors must read and acknowledge understanding of this Health and Safety Plan via their signature.

All injuries/accidents, including exposure incidents, shall be immediately reported to 375-2400 and the Project Manager.

\section{D.12 Task - Specific Work Practices}

\section{D.12.1 After Normal Business Hours/Night Work}

The largest consideration for working at night is poor visibility. Staff conducting field work must take precautions to avoid falls, tripping or slipping, or inadvertent encounters with nocturnal wildlife. Physical hazards such as falls, slick wet surfaces, pinch points, hazardous work sites, uneven surfaces, and working on or near water must be identified prior to conducting survey or observation work at night. Practices should include housekeeping, familiarity with work area, appropriate use of lights, and the buddy system.

The Field Team Leader will establish a point of Project Management Contact (Project Leader, Task Leader or appropriate Project delegate) for all fieldwork to be conducted during non-business hours. Prior to leaving for the field, the Field Team Leader will ensure that the Project Management Contact is informed as to the type of work, the work location, the names of field staff conducting the work, the field team cell phone number and the planned return-to-office time of day. Upon return to the office, the Field Team Leader will contact the Project Management delegate to confirm return to the laboratory from "After Normal Hours" work.

\section{D.12.2 Site Hazards}

Overall, the study site is well characterized and may contain slightly elevated levels of radionuclide or chemical contaminants compared to background locations. From an Occupational Safety standpoint, the study areas are assumed to be uncontaminated with hazardous waste materials unless otherwise posted. Staff will work to identify and address any hazards at the site that are not identified prior to sampling and/or survey. Staff will follow all site- or activity-specific safety plans that address activities or hazards identified in the job safety analysis for the task other than the physical hazards identified herein. In general, other hazards on survey sites may include the following hazards:

- vehicles and machinery

- heat stress

- hypothermia 
- falls/trips

- noise

- pinch points

- radiological contamination - the riparian zone is not a radiological control area

- smoke (inhalation, visibility)

- flammable fuel handling

- burns from falling/stepping into open fire

- insects

- snakes.

Overall, the health risks anticipated at site is rated as low. The greatest hazards are likely from vehicles and machinery operating at the site, tripping/falling (particularly when carrying equipment), pinch point injury, and heat stress or hypothermia.

For the simulated fire test, personnel should be aware of the additional threat of respiratory distress resulting from smoke inhalation. Combustion of plant biomass will release chemicals and particulate matter into the air that can disrupt normal lung function. Burns from falling into open fire during the simulated fire test could be serious especially and with limited access to treatment services at the site. Personnel should beware of inhaling too much smoke and those that are susceptible are advised to avoid the test site during times when smoke levels are high.

All personnel affiliated with this prescribed burn must remain aware of fire activity that threatens the control lines. In addition, all personnel must keep on the lookout for spots across the line. Any and all of these threats should be reported through the chain of command. Fires outside the burn unit must be suppressed immediately. Bosses of each unit must inform the Ignition Specialist/Firing Boss or Holding Group Leader of fire outside the control lines. Based on that information, the IC and/or Ignition Specialist/Firing Boss will evaluate the need to cease ignition while containing spot fires. An escaped fire requires the immediate change in strategy to suppression with the IC assuming command.

Safety zones for the burn crew will be the paved area adjacent to the connex box at the base of the gravel side slope (northwestern corner of the barrier). This zone will be reviewed prior to ignition, along with the 10 Fire Orders, 18 Watchout Situations, and Lookouts, Communications, Escape Routes, and Safety Zones (LCES) Principles. Hanford Fire Department (HFD) Dispatch will be contacted by radio or cell phone (509-373-2301) in the event that fire escapes and threatens government facilities or property. Each burn crewmember will wear proper personal protective equipment and follow LCES Principles, which include: carrying a personal fire shelter, a hand held radio, and drinking water. Should emergency medical response be necessary, an HFD ambulance will be dispatched. Contact HFD Dispatch (509-373-2301) if an ambulance is needed. In case of an escape fire, notifications will be made to the HFD Fire Chief and to FWS, in accordance with the current FWS Dispatch Plan. 


\section{D.12.3 Discussion of Specific Hazards}

\section{A. Physical Hazards}

\section{Operation of Vehicles}

\section{General Driving Instructions:}

All drivers must be in possession of a valid driver's license to operate a government vehicle and be qualified as a certified driver per SBMS driver training.

Drivers must be familiar with the vehicles operating instructions per the vehicle’s manual.

Obey all state motor vehicle laws and heed posted speed limits. Use of seat belts is mandatory any time the vehicle is in motion. Ensure that all passengers have securely fastened seat belts before putting the vehicle in motion.

Conduct a walk-around inspection of the vehicle before using it. Report immediately to your Project Manager and the Vehicle Custodian any damaged or defective vehicles. Do not operate a vehicle that has mechanical defects or low tire pressure. Before you enter the vehicle, ensure that the space behind the vehicle is clear if it is necessary to operate the vehicle in reverse gear.

Do not operate the vehicle if you are impaired in any way (sleepy, dizzy, on medication that may cause drowsiness, etc.). Do not operate cell phones or attend to other functions that may distract you while driving. Reduce speed and use a heightened sense of awareness when driving at dusk, during the night or at dawn when you are in locations where deer or elk may be present on the roadways.

\section{Driving on Unpaved Roadways:}

Some roads are primitive and, in most areas, no speed limit signs are posted along graveled and dirt roads. Driving should be limited to passable and safe unpaved roadways. Reduce your speed to match road conditions. Existing turn-around points should be used when available. Twenty-five (25) mph is the recommended maximum speed unless otherwise posted. Vehicles are not to be driven off established roads (off-road travel on the Hanford Site is not permitted by DOE policy and is also specifically excluded on the Hanford Reach National monument). In the case that driving off road is intended during fire season, the fire dept shall be contacted before proceeding and fire extinguishers shall be carried by all vehicles.

Catalytic converters generate extreme levels of heat and can easily ignite grasses and brush. Ensure that you park vehicles on surfaces free of combustible materials. Periodically check under the vehicle to ensure that vegetation or other materials have not been trapped there. Noxious weeds are present on many of the "established" roads we drive and these likely cannot be avoided. If driving off road during fire season contact fire dept and fire extinguishers

Carry two 10-pound fire extinguishers and 2 shovels in all vehicles that leave the paved roadways during the fire season (June through October). Fire extinguishers must have current annual and monthly inspections. If annual inspection is past due, contact the S\&H Rep at 371-7097. 


\section{Vehicles and Machinery}

Vehicles and machinery at industrial or roadway survey sites pose hazards that need to be addressed. The proposed study site is not expected to have heavy equipment present; however, there may be heavy equipment or vehicles on roads leading to the study areas. Personnel must remain aware of and avoid moving equipment. Vehicles must be assumed to have the right-of-way at all times. Traffic must be kept under observation when surveying near roadways. The buddy system will be used. Machinery (power auger, post driver, concrete mixer) will be used in the installation of electrodes for the survey. Hazards associated with the use of these tools include noise, pinch injuries, burns from the 2-cycle engine, fuel spills, and eye injury. The gas-powered trencher (ditch witch) is heavy, awkward, and noisy. Hearing protection, eye protection, and leather gloves will be worn when this tool is being used. In addition, the staff using the trencher will review the operating manual from the manufacturer and will operate this tool in accordance with the manufacturer's recommendations. . Therefore caution should be exercised when lifting, moving, or using these items, taking care to maintain good posture and avoid twisting with load to prevent fatigue, strain or overuse problems, backache, or muscular pain. Get help if the load exceeds 25 pounds. Check for obstacles in your path before moving loads. For deploying and recovering long cables, consider use of ATV or other vehicle to carry cable spool rather than carrying cable over shoulder.

\section{Geophysical Logging Equipment}

The neutron probe is the only piece of geophysical logging equipment that will need to be carried onto the site. This typical probe consists of a source of neutrons, usually $50 \mathrm{mCi}$ of americium-241 and beryllium, and a neutron detector. The neutrons given off by the source (called "fast" neutrons) collide with hydrogen atoms in any water present. The detector is set up only to measure slow neutrons, and the amount of slow neutrons detected is directly related to the amount of hydrogen present. The neutron probe is a considered to be a sealed radioactive source and appropriate precautions must be taken for the transport and use of this device. Radiation Worker II training is required for operators of neutron probes. Training records for these activities will be on file with the individual worker and will be available upon request.

Some field instrumentation is powered by d.c power supplied via solar panels and deep-cycle batteries. These batteries are sometimes recharged using a.c power. Sensors are connected to each other and to monitoring equipment using multi-conductor cables which could pose a hazard for trips and falls. Ground fault circuit interruption (GFCI) protection is required for all electrical connections and power tools unless battery powered.

\section{Weather}

Strong winds or heavy precipitation may require that sampling/survey activities at the site be curtailed. Stormy weather, and in particular, lightning storms may require that staff take cover. If thunder/lightning is present, staff will stop work and return to the vehicle; do not take cover beneath trees.

Hypothermia may be a problem if work takes place during cool weather. The following guide should be followed during a cold injury:

- bring victim into a warm area

- remove all wet/cold garments

- dry the victim and cover with blanket or dry clothes. 
Work in warm weather may lead to heat related illness [see Section VIII (2)]. Heat stroke victims are recognized by their dry skin (lesser degrees of heat-related illness commonly cause very damp skin). They will be disoriented and probably will not be able to respond to commands or to help themselves.

Heat stroke is life threatening. Prompt treatment of heat stroke must be given at the site for anyone stricken by this illness. Treatment includes cooling the victim with whatever is at hand (e.g., shade, river water bath, wetting the body with drinking water). Do not wait for medical services to arrive to begin treatment.

\section{Heat Stress}

Heat stress is a potential hazard during heavy exertion in the summer, especially if workers are insufficiently hydrated. Potable water should be carried into the field in appropriate containers when surveying in remote areas. Coffee, tea and caffeine-containing soft drinks should be avoided. The Field Team Leader shall determine if heat stress poses a particular risk during field work and shall have field team members monitor their pulse rate periodically and be alert for symptoms when heat stress potential is high.

Symptoms of heat stress include confusion, lightheadedness, decreased sweating, muscle cramps and increased heart rate. If a worker's pulse exceeds 110 beats per minute, a 15-minute break period in the shade and ingestion of water will be required.

If the ambient temperature is above $80^{\circ} \mathrm{F}$, or if strenuous work in heavy clothing is anticipated, the Field Team Leader shall take special precautions against heat stress. Workers shall force fluids prior to work (such as a good electrolyte replenishment drink) and monitor their vital signs, such as pulse, to lessen the likelihood of a heat related illness. To the extent possible, wear loose clothing of light colored lightweight fabrics. Hanford weather information is available at http://hms.pnl.gov/lastob.htm.

\section{Smoke Inhalation}

For the simulated fire test, personnel should be aware of the additional threat of respiratory distress resulting from smoke inhalation. Burns from falling into open fire during the simulated fire test could be serious especially and with limited access to treatment services at the site. Combustion of plant biomass, especially from plants high in resin content, can release chemicals, gases such as carbon monoxide and carbon dioxide, as well as particulate matter, into the air that disrupts normal lung function. Personnel should beware of inhaling too much smoke and those that are susceptible are advised to avoid the test site during times when smoke levels are high. Staff should be cognizant of wind direction and smoke plume direction to avoid exposure. To limit exposures, the safety zone during controlled burn will be located upwind from the controlled.

\section{Hypothermia}

Hypothermia, or severe decrease in body temperature, must be guarded against if work at the site takes place during temperatures below $65^{\circ} \mathrm{F}$. Workers may require insulated coveralls, heavy gloves, insulated waders, or pack boots. Hypothermia can also result when staff members get wet or fall into the river. Where there is elevated risk of hypothermia, have a blanket at the work site. 


\section{Slips/Trips/Falls}

As with all work sites, caution must be exercised to prevent slips on

- rain or wetted slick surfaces

- oily spots

- rough, uneven terrain (riprap)

- steep slopes

When working on steep uneven or rough terrain such as the rip rap side slopes, staff will wear appropriate footwear and apparel to minimize risks. Under some conditions, felt-soled boots can improve footing on rain and wetted slick surfaces. The buddy system will be used with cellular phones in remote areas to obtain help if someone becomes injured and unable to walk to a vehicle.

\section{Noise}

Surveys conducted in the vicinity of heavy machinery may lead to excessive noise exposure. Personnel in the immediate area must use hearing protection (e.g., foam inserts) if exposure to noise levels exceeding $85 \mathrm{~dB}$ is anticipated for over 15 minutes. Elevated noise levels are anticipated for all activities involving powered soil coring devices or post drivers and appropriate hearing protection must be used.

\section{Confined Spaces}

Twelve siphon vaults, located to the north of the barrier, are used to monitor drainage from the barrier and side slopes. The vaults are designated as confined spaces. Personnel are forbidden from entering any confined space for work on this project without adequate training and approvals.

\section{Anaphylaxis}

Anaphylaxis is a life-threatening type of allergic reaction commonly referred as anaphylactic shock or an anaphylactic reaction. Anaphylaxis is an emergency condition requiring immediate professional medical attention. It is the responsibility of an individual who has a history of allergy to insect bites/stings to advise their immediate supervisor of such a condition before any field work is conducted and carry an emergency kit consisting of injectable epinephrine and chewable antihistamine, if required. It is advisable (but their individual responsibility) that they should also wear a Medic-Alert or similar bracelet/necklace stating their allergy.

As with any medical emergency, if anaphylaxis is suspected while in a remote location, the singlepoint emergency contact (375-2400) should be notified immediately.

Anaphylaxis is an acute systemic (whole body) type of allergic reaction. It occurs when a person has become sensitized to a certain substance or allergen (that is, the immune system has been abnormally triggered to recognize that allergen as a threat to the body). On the second or subsequent exposure to the substance, an allergic reaction occurs. This reaction is sudden, severe, and involves the whole body. Tissues in different parts of the body release histamine and other substances. This causes constriction of the airways, resulting in wheezing; difficulty breathing; and gastrointestinal symptoms such as abdominal pain, cramps, vomiting, and diarrhea. Histamine causes the blood vessels to dilate (which lowers blood 
pressure) and fluid to leak from the bloodstream into the tissues (which lowers the blood volume), resulting in shock. Fluid can leak into the alveoli (air sacs) of the lungs, causing pulmonary edema. Hives and angioedema (hives on the lips, eyelids, throat, and/or tongue) often occur, and angioedema may be severe enough to cause obstruction of the airway. Prolonged anaphylaxis can cause heart arrhythmias.

Symptoms of anaphylaxis include difficulty breathing (nasal congestion, cough, wheezing), confusion, slurred speech, fainting, light-headedness, dizziness, rapid or weak pulse, blue lips or fingertips, skin redness, hives or generalized itching, anxiety, nausea, vomiting, diarrhea, abdominal cramps or pain. Symptoms develop rapidly, often within seconds or minutes. For additional information see: http://www.nlm.nih.gov/medlineplus/ency/article/000844.htm

\section{B. Radiological Hazards}

The potential for exposure to ionizing radiation is considered possible in some areas of the Hanford Site. The potential for radiological contamination is considered to be minimal outside of surface contamination areas. The BY and BX tank farms are located immediately to the east and southeast of the barrier. Staff should be aware that radiological hazards potentially exist at the site. The barrier is also designated as an Underground Radioactive Materials Area (URMA). An URMA is established to indicate the presence of underground items that contain radioactive materials such as the underlying contaminated crib (B-57) at the PSB. The current posting includes a special instruction to consult with the radiological control organization before digging. This general requirement applies for all digging below a 2-m depth within the perimeter of the designated area, since more than $5 \mathrm{~m}$ of clean material was placed on the surface barrier. The site is also subject to the transport of radiological materials via wind or biological vectors. Under the current posting, the site is exempt from the general entry and exit requirements provided individual doses do not exceed 100 mrem in a year. In the event that staff are directed to enter a radiological control area, only staff with the proper training, clothing, and under the requirements specified in the Radiation Work Permit for that area will enter surface contamination areas. Staff will inform the Task Manager or Project Manager in planning for entry to radiation areas and the task will be coordinated with the appropriate site contractor.

\section{D.13 Personal Protection Equipment}

Field work is not expected to involve contaminated material, but the following personal protective equipment (PPE) will be worn as noted for protection from environmental extremes and field conditions. Closed-toe shoes are required for all field work. Common "PPE" that may be specified for work by the Task Manager or by the Field Team Leader may include:

- outdoor work clothing (clothing providing adequate protection from the elements encountered in the conduct of the work)

- hardhat - when work is being conducted near construction, or industrial areas or near drilling rigs

- goggles/safety glasses (as needed)

- ear protection (as needed)

- standard work footwear (steel-toed boots in construction areas, industrial areas, or abandoned buildings, or when working with heavy equipment)

- gloves appropriate for the job (leather for work with tools and equipment) 


\section{D.14 Emergency Procedures}

All field staff shall be trained in the use of cellular telephones.

For fire, police, medical emergency or ambulance, call Single Point Contact

$375-2400$

If unable to reach Single Point Contact, call Hanford Patrol

$373-3800$

If unable to reach Single Point Contact or Hanford Patrol, call

For medical assistance or guidance call:

Advanced Med Hanford First Aid Station

$376-3333$

Kadlec Hospital (emergency room nurse)

946-4611

PNNL Manager Fluor Projects Mark Freshley

372-6094

PNNL Project Manager, Andy Ward

$372-4417$

S\&H Representative, Douglas Falk

372-3067

If staff is unable to contact anyone in the work group, they may call 375-2154 (Battelle Security Research and Operations Building) to obtain after-hours assistance in case of non-threatening situations (e.g., immobilized vehicle). Immediately notify site emergency services (above). If a telephone is available, call the emergency assistance number (375-2400) and be prepared to describe the accident and your location (the site is west of 241-BY Tank Farm, with primary access off 12th street). In the absence of communication devices, send someone for help to the First-Aid Station at Schaws and 20th Street (Building 2719WB in 200 west area). Notify your line manager and the project manager (Andy Ward, 372-4417). Also notify Fluor Hanford’s single point contact, Jerry Cammann at 376-2037.

If medical attention is required, the affected party shall go to the closest fire station located between 200 East/200 West Area. The Project Manager must log a complete report of any event requiring use of outside agencies for any emergency action. Also, the Project Manager must log any event that requires implementation of the Emergency Procedures section of the Plan.

All injuries/accidents, including exposure incidents, shall be immediately reported to 375-2400 and the Project Manager. If directed to be evaluated by a physician, the affected worker shall immediately report for examination and follow all of the doctor's recommendations. The Project Manger or his designee will notify PNNL management and the Safety and Health Rep of any incidents. A written report of the injury or occupational illness (http://sbms.pnl.gov/standard/28/2802e010.doc) needs to be completed by the line manager the following day and forwarded to Laboratory Safety. If the injury or illness is recordable, the line manager must conduct a critique.

A worker requiring medical attention must be accompanied by another worker to the place of treatment. For cases involving more than simple first aid, or where there is any doubt as to the need for a doctor's opinion, medical attention must be received. The patient must notify the Project Manager as to the outcome of the medical evaluation as soon as possible. For minor cuts and bruises, a first aid kit will be available in the field vehicle. Ensuring the availability of safety equipment is the responsibility of the Field Team Leader.

Staff shall carry or have a programmed list of phone numbers for points of contact in the office and for emergencies. Staff shall also contact Project/Task Managers in non-threatening situations such as loss of transportation. 
Staff must also be aware of WARNING SIRENS that may be activated in the area and the appropriate actions in the event of siren warnings. The staging area for the is the 12th Street road entrance to the Prototype Barrier. For all gongs and horns go to the staging area. The following action should be taken relative to warning sirens:

- Wavering Siren: Get in vehicle, call emergency phone \# and follow directions

- Howler (AH-OO-GAH): Get in vehicle drive off the barrier and leave area-preferably away from the criticality area.

Planned siren tests are frequent. Call Dyncorp Emergency Prep. (373-4308) if questions arise regarding specific siren tests.

In the event that warning sirens are operated at the adjacent tank farms, leave the site immediately, and drive west on 12th Street (exit from the area via the unpaved road that turns south at the western end of 12th St.) rather that using Baltimore Street.

\section{D.15 Specific Training}

There are specific training requirements for the staff working on the Monitoring project, particularly on tasks related to water balance monitoring. These requirements generally follow 29 CFR 1910 even though the sampling locations and work are performed away from any waste sites where personnel exposure is a concern. The sampling areas are accessible to the general public. General requirements include:

1. Hanford General Employee Training, 2-4 hours, general PNNL General Employee Radiological Training (GERT) radiological training

2. First-Aid/CPR. One member of the contractors on-site field team must be First-Aid/CPR qualified.

Radiation Worker II training is required for operators of neutron probes and Enclosed Space Training is required for staff that repair dosing siphons. Training records for these activities will be on file with the individual worker and will be available upon request. Staff participating in field activities will meet with the Task Manager on a mutually agreeable schedule to discuss any revisions in instrumentation, data collection, and safety issues for the planned work. On arriving in the field and prior to the start of activities, the field crew will conduct an informal review of conditions and planned activities.

Signing this document provides the authority to access the site and perform testing and monitoring work at the prototype barrier; it does not provide the authority to operate any systems present at the site (e.g., the irrigation machine). Such additional work authorization shall be evaluated and delegated by the project manager and may require additional training.

\section{D.16 References}

PNL-MA-26 Radiological Control Procedures

PNL-MA-43 Industrial Hygiene, Occupational Safety and Fire Protection Programs.

PNL-MA-50 Facilities Management Department PNL Operations Manual.

SBMS Standards Based Management Systems-Subject Areas

OHE-002 QA Plan for the PNNL Surface Barrier Technology Project. 

PNNL-17859

\section{Distribution}

No. of

Copies

2 DOE-Richland

BL Charboneau A6-38

KD Leary

1 EPA-Richland

LC Buelow

B1-46

1 Ecology

M Mandis

5 Fluor Hanford, Inc.

GT Berlin (2)

JW Cammann (2)

DL Fort

1 CH2M Hill

CD Wittriech

E6-44

E6-44

R3-60

H6-03
No. of

Copies

13 Local Distribution

Pacific Northwest National Laboratory

RE Clayton

K6-75

JE Downs

K6-85

KE Draper

K6-75

MJ Fayer

K9-33

GW Gee

K9-33

N Hasan

K9-33

CE Strickland

K9-33

AL Ward (5)

K9-33

Hanford Technical Library

P8-55

Distr.1 



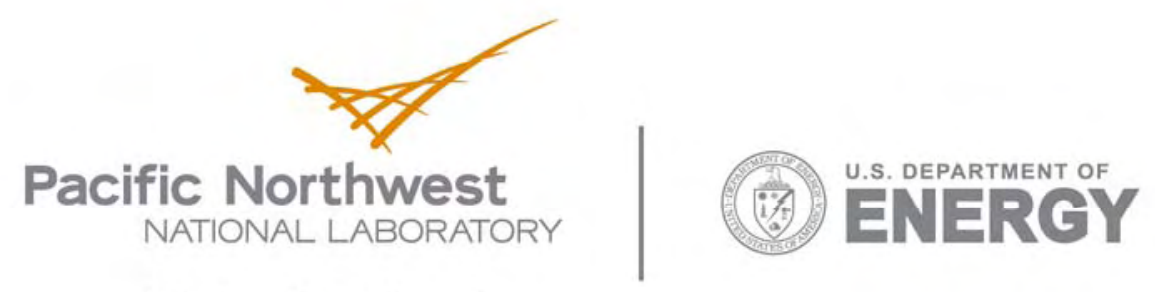

902 Battelle Boulevard

P.O. Box 999

Richland, WA 99352

1-888-375-PNNL (7665)

www.pnl.gov 